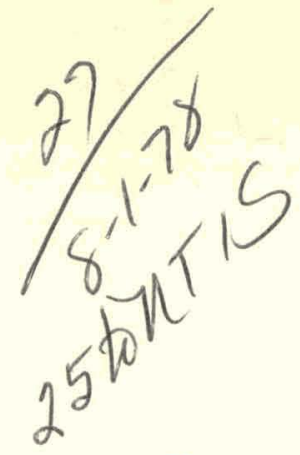

\title{
Assessment of Environmental Control Technology for Coal Conversion Aqueous Wastes
}

\author{
J. A. Klein \\ R. E. Barker
}




\section{DISCLAIMER}

This report was prepared as an account of work sponsored by an agency of the United States Government. Neither the United States Government nor any agency Thereof, nor any of their employees, makes any warranty, express or implied, or assumes any legal liability or responsibility for the accuracy, completeness, or usefulness of any information, apparatus, product, or process disclosed, or represents that its use would not infringe privately owned rights. Reference herein to any specific commercial product, process, or service by trade name, trademark, manufacturer, or otherwise does not necessarily constitute or imply its endorsement, recommendation, or favoring by the United States Government or any agency thereof. The views and opinions of authors expressed herein do not necessarily state or reflect those of the United States Government or any agency thereof. 


\section{DISCLAIMER}

Portions of this document may be illegible in electronic image products. Images are produced from the best available original document. 


\section{Printed In the Uniled Slales ul Arrerica. Available from National Technical Information Service}

U.S. Department of Commerce 5285 Port Royal Road, Springfield, Virginia 22161

Price: Printed Copy $\$ 6.50$; Microfiche $\$ 3.00$

This report was prepared as an account of work sponsored by an agency of the United States Government. Neither the United States Government nor any agency thereof, nor any of their employees, contractors, subcontractors, or their employees, makes any warranty, express or implied, nor assumes any legal liability or responsibility for any third party's use or the results of such use of any information, apparatus, product or process disclosed in this report, nor represents that its use by such third party would not infringe privately owned rights. 
ORNL/TM-6263

\section{MASTER}

Contract No. W-7405-eng-26

CHEMICAL TECHNOLOGY DIVISION

ASSESSMENT OF ENVIRONMENTAL CONTROL TECHNOLOGY

FOR COAL CONVERSION AQUEOUS WASTES

J. A. Klein and R. E. Barker

Date Published - July 1978

This report was prepared as an account of work This report was prepared as an account of work Sponsored by the United States Government. Neither the Energy, nor any of their employees, nor any of their Energy, nor any of their employees, nor any of their contractors, subcontractors, or their employees, makes
any warranty, expitess or implied, or assumes any legal any warpanty. expitiss or implied, or assumes any legal liability or responsibitity for the accuracy, completeness
ur usefulness of any information, apparatus, product or or usefulness of any information, apparatus, product or
process diselosed, or represents that its use would not infringe privately owned rights.

OAK RIDGE NATIONAL LABORATORY

Oak Ridge, Tennessee 37830 operated by

UNION CARBIDE CORPORATION

for the

DEPARTMENT OF ENERGY 
THIS PAGE

\section{WAS INTENTIONALLY \\ LEFT BLANK}




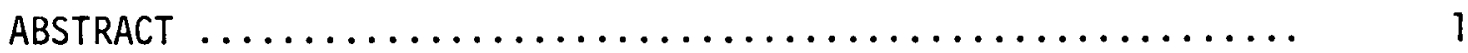

1. CONCLUSIONS AND RECOMMENDATIONS $\ldots \ldots \ldots \ldots \ldots \ldots \ldots \ldots \ldots$

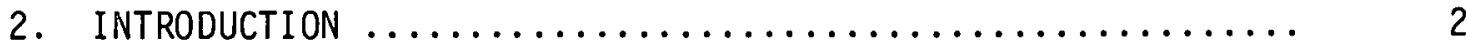

3. PROCESS DESCRIPTION $\ldots \ldots \ldots \ldots \ldots \ldots \ldots \ldots \ldots \ldots \ldots \ldots \ldots \ldots$

4. IDENTIFICATION OF WASTEWATER STREAMS $\ldots \ldots \ldots \ldots \ldots \ldots \ldots \ldots$

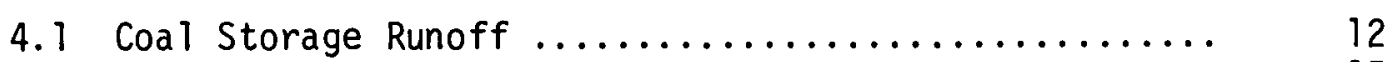

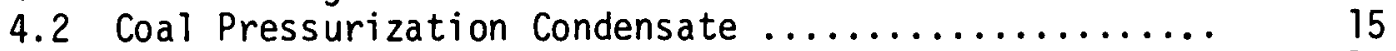

4.3 Hydrocarbonization Product Water ................ 16

4.4 Acid-Gas Removal and Hydrocarbon

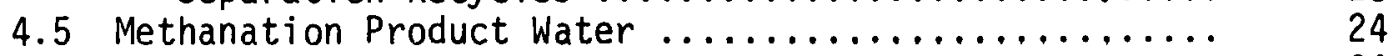

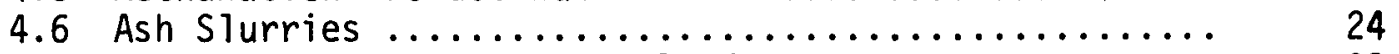

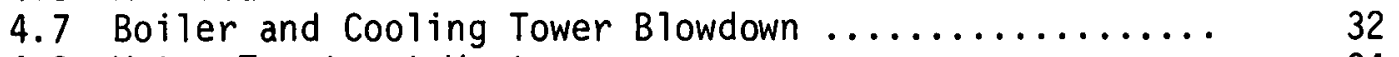

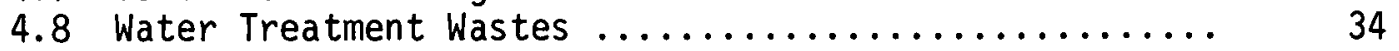

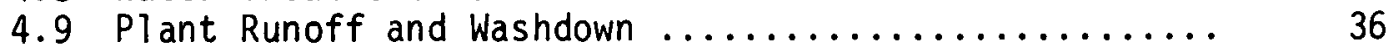

5. MAJOR CONTAMINANTS $\ldots \ldots \ldots \ldots \ldots \ldots \ldots \ldots \ldots \ldots \ldots \ldots \ldots \ldots \ldots \ldots$

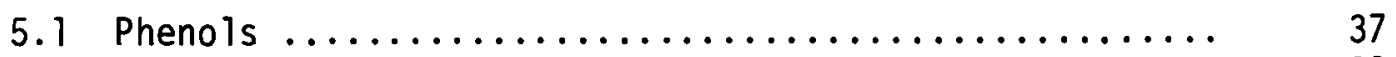

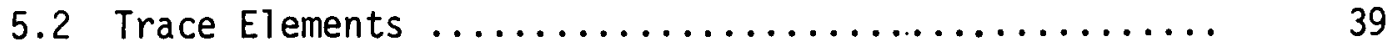

5.3 Polynuclear Aromatic Hydrocarbons .............. 47

6. GOVERNMENTAL REgULATIONS .................... 49

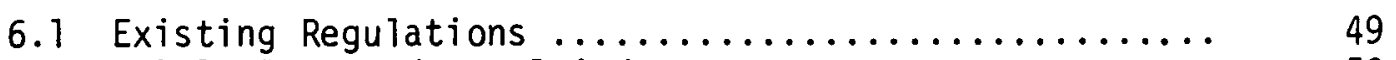

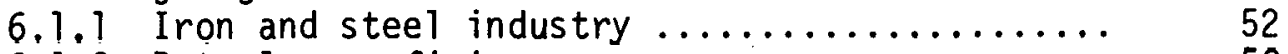

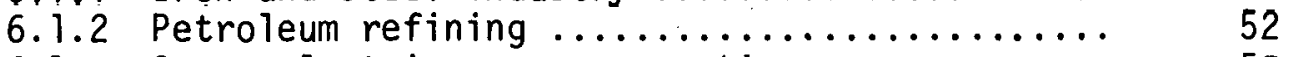

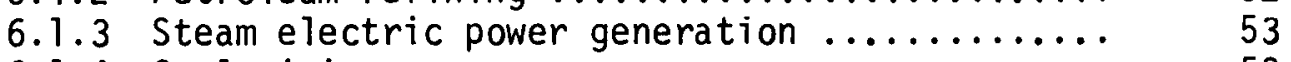

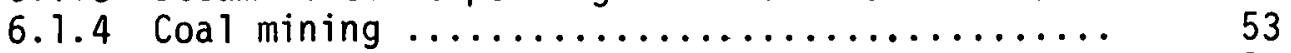

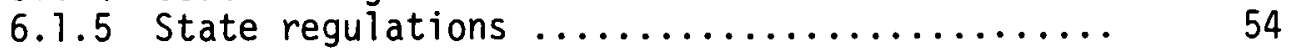

6.2 Anticipated Regulations .................. 54

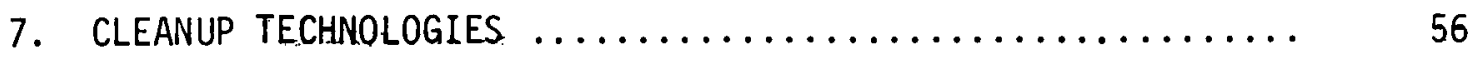

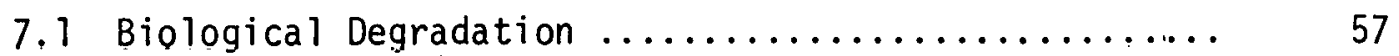

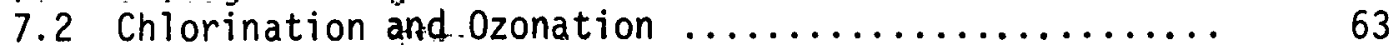

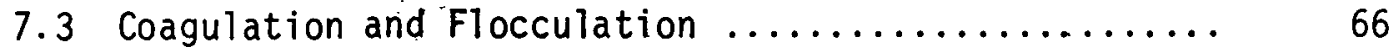

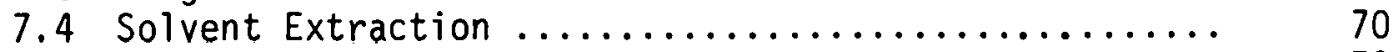

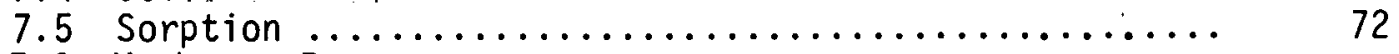

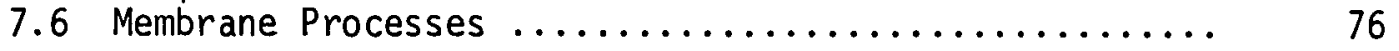

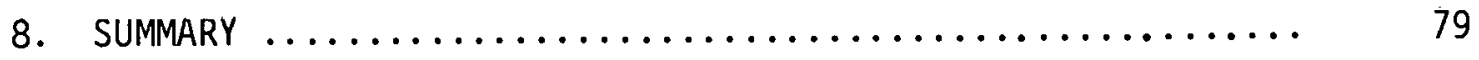

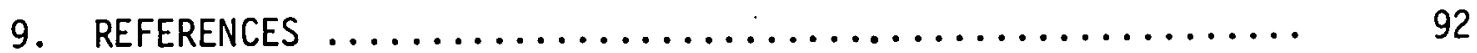


ASSESSMENT OF ENVIRONMENTAL CONTROL TECHNOLOGY FOR COAL CONVERSION AQUEOUS WASTES

J. A. Klein and.R. E. Barker

ABSTRACT

The commercial design of a coal hydrocarbonization plant was studied to define the problem of wastewater. The wastewater streams were identified and the literature was reviewed to determine the amounts and components of the various wastewater streams. Although no federal effluent guidelines exist for coal conversion plants, the effluent guidelines of related industries were studied so that future effluent guidelines for coal conversion plants could be anticipated. Several cleanup technologies were assessed for their:adaptability to coal conversion wastewaters.

\section{CONCLUSIONS AND RECOMMENDATIONS}

This report defines the wastewater problem in a hydrocarbonization process such as that described in the Coalcon ${ }^{1}$ coal conversion flowsheet. Many of the wastewater streams will, theoretically, be completely recycled internally, and thus may not be of concern. Others are fairly well defined, and adequate cleanup technology exists to bring these streams into compliance with any reasonable regulations.

However, many streams are not well characterized either in quantity of flow or in pollutant content. This is particularly true of the organic content (e.g., PNA, phenols) of the cooling tower streams, caused by leaks from process streams to cooling water streams, and the 
trace-element content of the ash slurry to the ash pit. These are the streams for which it will be most difficult to apply adequate cleanup technology. Of greatest concern to those involved in wastewater cleanup will be the content of phenols, polynuclear hydrocarbons (PNAs), and trace elements.

It is recommended that:

1. Additional analytical research should be carried out in the characterization of the following critical wastewater streams: (1) runoff from plant grounds and coal storage; (2) water streams from the hydrocarbonization reactor, ammonia stripping, and condensate from the hydrocarbon separation unit; and (3) ash and slag quenching, and sluicing water and leachate from stored ash and slag.

2. Additional reliability studies should be conducted to quantify leak rates into the cooling water through the many heat exchangers that will be needed in a coal conversion plant.

3. Future research studies should be conducted to detcrmine acceptable effluent limits for PNAs and a variety of trace elements. This should be done from the standpoint of a-best-available technology, as well as based on the relative hazards to human health and the environment of the potential pollutants.

4. Sr.reening tests should be performed to assess the adaptability of a variety of presently available and advanced cleanup technolngies to coal conversion wastewaters.

\section{INTRODUCTION}

In order to commercialize the production of clean (i.e., low-sulfur, low-ash) boiler fuel from coal, the Department of Energy (DOE) is studying 
many coal conversion processes. This report describes the wastewater problem of coal conversion using the Coalcon hydrocarbonization design.' The design work for the coalcon hydrocarbonization process was recently suspended for various economic and technical reasons. The Coalcon flowsheet, however, still describes a representative coal conversion process that can be used to determine the wastewater problem. The disposal of wastewater from coal conversion plants is not a trivial problem. To meet the goal of replacing $20 \%$ of the present oil consumption in the United States with clean fuels from coal, it will take about 80 large $(12,000$ to 20,000 tons/day $)$ coal conversion plants. ${ }^{2}$ A coal conversion industry of these proportions would produce a very large amount of wastewater $\left(4 \times 10^{8}\right.$ to $8 \times 10^{8}$ tons/year). Although this is considerably smaller than the wastewater produced in the petroleum refining industry $\left(\sim 2 \times 10^{10}\right.$ tons/year), ${ }^{3,4}$ it is a significant amount of waste.

Hydrocarbonization is one of the more completely investigated coal conversion technologies and is a likely process for commercialization for the following primary reasons:

1. Only low-sulfur gaseous and liquid products are produced.

2. Hydrocarbonization is a noncatalytic process.

3. There is no difficult solid-liquid separation as in the Solvent Refined Coal (SRC), COED, Synthoil, and H-COAL processes.

For these reasons, an environmental evaluation of hydrocarbonization is a timely project. 
As of December 1977, no evaluations of environmental control technology for the hydrocarbonization process were available. However, evaluations of other processes have been published. Exxon Corporation has published evaluations of several gasification and liquefaction processes ${ }^{5-15}$ in conjunction with the Environmental Protection Agency. (EPA). Under contract with the EPA, Booz-Al len Applied Research Corporation has also published an evaluation of several clean fuel processes. ${ }^{16}$ Uther coal conversion environmental evaluations have also been published. 17,18

Coal conversion aqueous wastes are often compared with their counterpart in the coke production industry. For this reason, the phenolic and light-oil components of the wastewater are well characterized and have generally been anticipated. Hydrocarbonization will produce greater quantities of these pollutants and will have more serious ammonia, hydrogen sulfide, and trace-element problems.

This report represents an effort to identify the sources, composition, and hazardous level of the aqueous effluents from coal hydrocarbonization. In addition, existing and anticipated effluent guidelines for coal conversion have been evaluated. Present commercial and developing technologies have been assessed for their ability to treat these aqueous wastes.

\section{PROCESS DESCRIPTION}

Hydrocarbonization denotes contacting of coal and gaseous hydrogen (usually in a fluidized bed) at intermediate temperatures (425 to $650^{\circ} \mathrm{C}$ ) and pressures ( $\leq 100 \mathrm{~atm})$. Hydrocarbonization was developed in the 1950s 
and 1960s by Union Carbide Corporation to produce chemical feedstocks. A 20-ton/day pilot plant was successfully operated in the early 1960s using a low-sulfur, nonagglomerating coal. ${ }^{19}$ The hydrocarbonization process was not commercialized at that time because it could not compete with the cheaper petroleum feedstocks that were available in 1964.

The proposed hydrocarbonization scheme calls for the conversion of 628 tons of coal per hour to liquid and gaseous products, as well as ammonia and elemental sulfur by-products. The product breakdown is shown in Table 3.1. The solid hydrocarbonization char is totally consumed for process hydrogen production and process heat generation in a Texaco partial-oxidation gasifier and conventional steam plant.

Figure 3.1 is a schematic diagram of the hydrocarbonization process. Table 3.2 is a description of the streams shown in Fig. 3.1. In the following discussion, the numbers in parentheses refer to the streams listed in Table 3.2. The flow rates have either been taken directly from or have been calculated from material balance information in ref. 1. More detailed process descriptions are available. 1,20 Run-of-mine coal (stream 1) is delivered and stored in one of two types uf storage. Live storage is short-term storage from which the coal will be used in a relatively short period of time. Dead storage refers to additional long-term storage that is to be used in case the normal delivery of coal is stopped. The coal (stream 4) is taken from storage and is crushed, dried, pressurized to $555 \mathrm{psi}$, and heated to about $325^{\circ} \mathrm{C}$. The dried, heated coal (stream 12) is then fed by lock hoppers to the hydrocarbonizer, which operates at $560^{\circ} \mathrm{C}$ and 555 psia with a hydrogen partial pressure at the gas inlet of 527 psia. The 
Table 3.1. Hydrocarbonization product summarya

\begin{tabular}{lcc}
\hline \multicolumn{1}{c}{ Product } & $\begin{array}{c}\text { Production } \\
\text { rate } \\
(\text { per day) }\end{array}$ & $\begin{array}{c}\text { Heating value } \\
\text { as percent } \\
\text { of rnal feed }\end{array}$ \\
\hline Heavy fuel oil & $13,153 \mathrm{bbl}$ & $2 \mathrm{~b} .57$ \\
Gasoline fraction & $6,788 \mathrm{bbl}$ & 9.56 \\
LPG product & $4,387 \mathrm{bbl}$ & 4.94 \\
Pipeline SNG & $105 \times 10^{6}$ scf & 30.01 \\
Anhydrous ammonia & 48.4 tons & 0.26 \\
Sulfur (elemental) & 352.4 tons & 0.77 \\
Total heat feed retained in products (thermal efficiency) & 68.21 \\
\hline
\end{tabular}

${ }^{\text {a }}$ ata adapted from ref. 1, p. 2-44. 
ORNL-DWG 76-14613 R

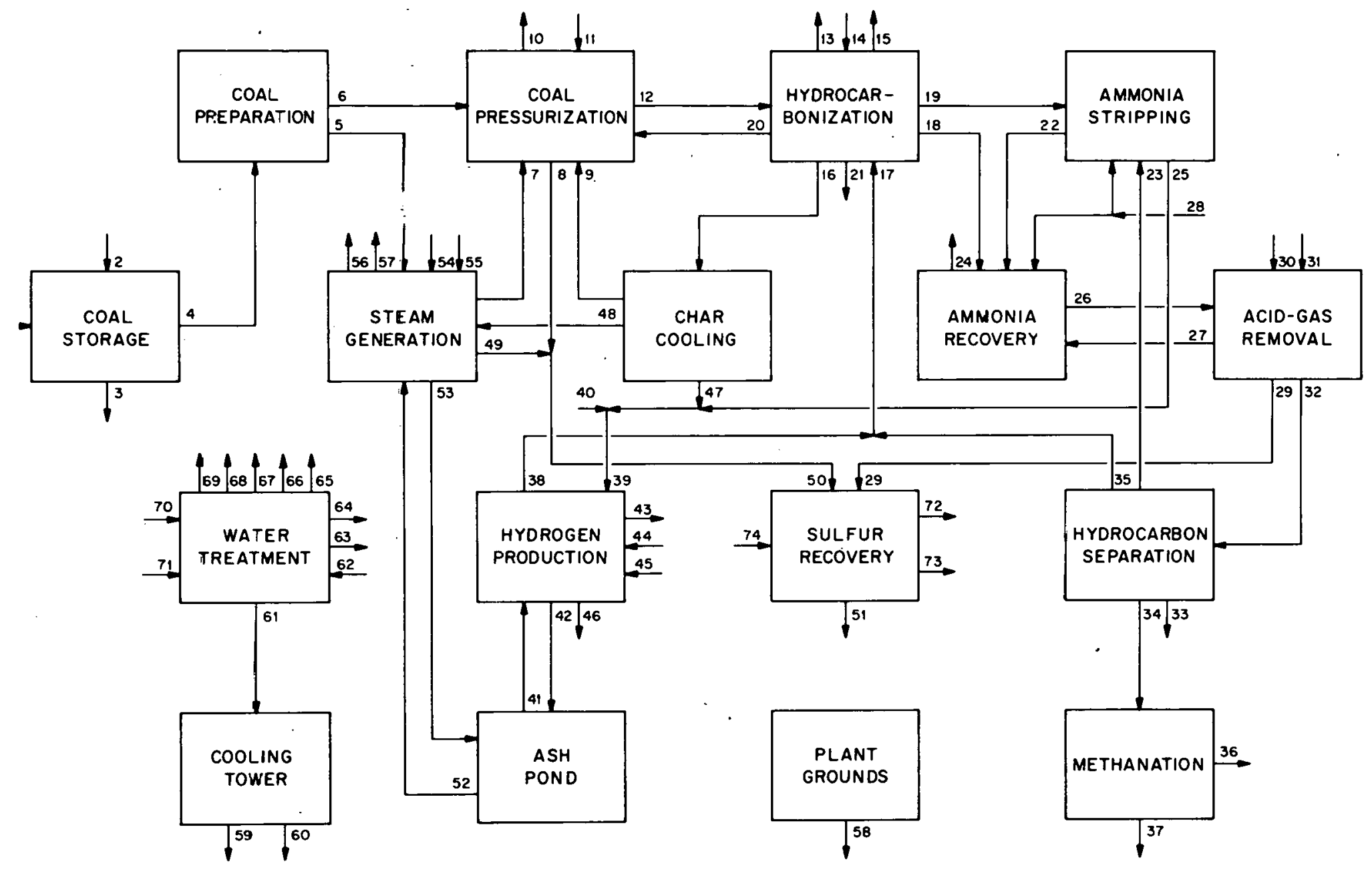

Fig. 3.1. Schematic-hydrocarbonization plant. 
Table 3.2. Identification of hydrocarbonization process streams

\begin{tabular}{|c|c|}
\hline $\begin{array}{l}\text { Stream } \\
\text { No. }\end{array}$ & Stream description \\
\hline 1 & Coal from mine, 628 tons $/ \mathrm{hr}$ \\
\hline 2 & Rainwater to coal storage \\
\hline $3^{a}$ & Rainwater runoff from coal storage, $530 \mathrm{lb} / \mathrm{hr}$ \\
\hline 4 & Coal feed to crushing, 628 tons $/ \mathrm{hr}$ \\
\hline 5 & Coal to boiler, 35.1 tons/hr \\
\hline 6 & Coal to hydrocarboni 2 alion, 593 tons $/ \mathrm{hr}$ \\
\hline 7 & Dry flue gas to coal drying, $1,080,428 \mathrm{lb} / \mathrm{hr}$ \\
\hline 8 & Wet flue gas to $s 117$ fur recovery, $1,092,112 \mathrm{lW} / \mathrm{hr}$ \\
\hline 9 & Steam from char cooling, $5000 \mathrm{lb} / \mathrm{hr}$ \\
\hline $10^{\mathrm{a}}$ & $\begin{array}{l}\text { Contaminated condensate, } 125,000 \mathrm{lb} / \mathrm{hr} \text { (steam made } \\
\text { from contacting water with hot char) }\end{array}$ \\
\hline 11 & Steam, $60,642 \mathrm{lb} / \mathrm{hr}$ \\
\hline 12 & Pressurized coal, 1,089,167 lb/hr \\
\hline 13 & Heavy fue 1 oil to storage, $211,779 \mathrm{lb} / \mathrm{hr}$ \\
\hline 14 & Water (to be converted to steam by char contact) \\
\hline 15 & Light fuel oil, $78,936 \mathrm{lb} / \mathrm{hr}$ \\
\hline 16 & $\begin{array}{l}\text { Char and transport steam, } 5000-1 \mathrm{~b} / \mathrm{hr} \text { steam, } \\
513,144-1 \mathrm{~b} / \mathrm{hr} \text { char }\end{array}$ \\
\hline 17 & Hydrogen gas, 208,106 1b/hr. \\
\hline 18 & Light gases from reactor, $397,069 \mathrm{lb} / \mathrm{hr}$ \\
\hline $19^{\mathrm{a}}$ & $\begin{array}{l}\text { Reactor aqueous product, } 105,056 \mathrm{lb} / \mathrm{hr} \text { to ammonia } \\
\text { stripping }\end{array}$ \\
\hline 20 & $\begin{array}{l}\text { Steam from hydrocarbonization to pressurization, } \\
85,274 \mathrm{it} / \mathrm{hr}\end{array}$ \\
\hline 21 & Agglomerates, approx 160-1b/hr char \\
\hline 22 & Ammonia=rich vapor stream tu anmonia recovery \\
\hline $23^{\mathrm{a}}$ & Condensate recycle, $12,331 \mathrm{lb} / \mathrm{hr}$ \\
\hline 24 & Ammonia product, $4067 \mathrm{lb} / \mathrm{hr}$ \\
\hline $25^{\mathrm{a}}$ & $\begin{array}{l}\text { Wastewater from ammonia stripping to char slurrying, } \\
175,000 \mathrm{lb} / \mathrm{hr}\end{array}$ \\
\hline 26 & $\begin{array}{l}\text { Gas from ammonia stripping to acid gas removal, } \\
472,000 \mathrm{lb} / \mathrm{hr} \text { (ethane, methane, } \mathrm{H}_{2} \mathrm{~S} \text {, etc.) }\end{array}$ \\
\hline
\end{tabular}


Table 3.2 (continued)

\begin{tabular}{|c|c|}
\hline $\begin{array}{l}\text { Stream } \\
\text { No. }\end{array}$ & Stream description \\
\hline $27^{\mathrm{a}}$ & Wastewater recycle, $52,000 \mathrm{lb} / \mathrm{hr}$ \\
\hline 28 & Steam, $18,000 \mathrm{lb} / \mathrm{hr}$ \\
\hline 29 & $\mathrm{H}_{2} \mathrm{~S}$-rich stream to sulfur recovery, $13,300 \mathrm{lb} / \mathrm{hr}$ \\
\hline 30 & Steam, $20,000 \mathrm{lb} / \mathrm{hr}$ \\
\hline 31 & Water, $32,000 \mathrm{lb} / \mathrm{hr}$ \\
\hline 32 & Clean gas to hydrogen purification, $380,000 \mathrm{lb} / \mathrm{hr}$ \\
\hline 33 & LPG product to storage, $34,600 \mathrm{lb} / \mathrm{hr}$ \\
\hline 34 & Synthes is gas to methanation, $168,917 \mathrm{lb} / \mathrm{hr}$ \\
\hline 35 & Hydrogen recycle to reactor, $32,895 \mathrm{lb} / \mathrm{hr}$ \\
\hline 36 & SNG product to storage, $206,282 \mathrm{lb} / \mathrm{hr}$ \\
\hline $37^{\mathrm{a}}$ & Wastewater, $38,000 \mathrm{lb} / \mathrm{hr}$ \\
\hline 38 & Makeup hydrogen from Texaco unit, $162,865 \mathrm{lb} / \mathrm{hr}$ \\
\hline 39 & $\begin{array}{l}\text { Char-water slurry to Texaco unit, } 354,663-1 \mathrm{~b} / \mathrm{hr} \text { char, } \\
250,292-1 \mathrm{~b} / \mathrm{hr} \text { water }\end{array}$ \\
\hline 40 & Makeup water to char slurrying, $-75,000 \mathrm{lb} / \mathrm{hr}$ \\
\hline 41 & Sluicewater return from ash pond \\
\hline $42^{\mathrm{a}}$ & $\begin{array}{l}\text { Ash slurry to pond from Texaco unit, } 86,581 \mathrm{lb} / \mathrm{hr} \text {, } \\
10 \% \mathrm{H}_{2} \mathrm{O}\end{array}$ \\
\hline $43^{\mathrm{a}}$ & Gasifier water jacket blowdown, $1715 \mathrm{lb} / \mathrm{hr}$ \\
\hline 44 & Steam, $70,000 \mathrm{lb} / \mathrm{hr}$ \\
\hline 45 & Makeup water, $68,430 \mathrm{lb} / \mathrm{hr}$ \\
\hline 46 & Quench evaporation \\
\hline 47 & Char to Texaco unit, $354,663 \mathrm{lb} / \mathrm{hr}$ \\
\hline 48 & Char to boiler, $158,481 \mathrm{lb} / \mathrm{hr}$ \\
\hline 49 & Boiler flue gas to sulfur recovery, $1,574,284 \mathrm{lb} / \mathrm{hr}$ \\
\hline 50 & Sulfur recovery flue gas feed, $2,666,396 \mathrm{lb} / \mathrm{hr}$ \\
\hline 31 & Desulfurized flue gas to stack, $3,527,940 \mathrm{lb} / \mathrm{hr}$ \\
\hline 52 & Ash sluicewater return, $308,331 \mathrm{lb} / \mathrm{hr}$ \\
\hline $53^{a}$ & $\begin{array}{l}\text { Ash slurry to ash pit, } 34,259-1 \mathrm{~b} / \mathrm{hr} \text { ash, 308,331- } \\
\text { water }\end{array}$ \\
\hline
\end{tabular}


Table 3.2 (continued)

\begin{tabular}{|c|c|}
\hline $\begin{array}{c}\text { Stream } \\
\text { No. }\end{array}$ & Stream description \\
\hline 54 & Sluicewater makeup \\
\hline 55 & Boiler feed water, $1,623,800 \mathrm{lb} / \mathrm{hr}$ \\
\hline 56 & Steam, $1,593,800 \mathrm{lb} / \mathrm{hr}$ \\
\hline $57^{\mathrm{a}}$ & Boiler blowdown, $\sim 30,000 \mathrm{lb} / \mathrm{hr}$ \\
\hline $58^{\mathrm{a}}$ & Contiminated rainwater runoff of plant grounds \\
\hline $59^{\mathrm{a}}$ & Cooling tower blowdown, $358,000 \mathrm{lb} / \mathrm{hr}$ \\
\hline 60 & Couling tower losses \\
\hline 61 & Cooling tower makeup, $4,081,000 \mathrm{lb} / \mathrm{hr}$ \\
\hline 62 & River water, $5,658,500 \mathrm{lb} / \mathrm{hr}$ \\
\hline 63 & Boiler feed water, $3,410,000 \mathrm{lb} / \mathrm{hr}$ \\
\hline 64 & Potable water, $150,000 \mathrm{lb} / \mathrm{hr}$ \\
\hline 65 & Wastewater to Texaco unit, $50,000 \mathrm{lb} / \mathrm{hr}$ \\
\hline $66^{\mathrm{a}}$ & Clarifier blowdown, $70,000 \mathrm{lb} / \mathrm{hr}$ \\
\hline $67^{\mathrm{a}}$ & Blowdown from demineralizer, $265,000 \mathrm{lb} / \mathrm{hr}$ \\
\hline 68 & Water to ammonia recovery, $89,300 \mathrm{lb} / \mathrm{hr}$ \\
\hline 69 & Turbine condensate \\
\hline 70 & Boiler feed water return \\
\hline 71 & Steam \\
\hline 72 & Sulfur product, $15,720 \mathrm{lb} / \mathrm{hr}$ \\
\hline 73 & $\mathrm{NaSO}_{4}$ product, $528 \mathrm{lb} / \mathrm{hr}$ \\
\hline 74 & Air to incineration, $-900,000 \mathrm{lb} / \mathrm{hr}$ \\
\hline
\end{tabular}

${ }^{a}$ Denotes wastewater stream. 
solids residence time in the reactor is $-25 \mathrm{~min}$. The unreacted solids and char (stream 16) are cooled and sent to the hydrogen-production or steam-generation units. The reactor overhead product is quenched with a recirculating oil scrub and fed to a 40-tray fractionator. The fractionator bottoms (stream 13) is a heavy, high-boiling boiler feed, and the overhead product is separated into gas (stream 18), light oil (streain 15), and aqueous phases (stream 19). The light oil is the lowboiling "gasoline fraction" and is sent to product storage. The aqueous phase is steam stripped to remove ammonia for recovery and is sent to the hydrogen production gasifier (stream 25). The gas.phase (stream 18) and the overhead from the ammonia stripper (stream 22) are sent to a gas cleanup section for removal and recovery of ammonia (using the U.S. Steel Phosan-W process) and hydrogen sulfide (using the Rectisol process). The anhydrous ammonia (stream 24) is sent to product storage, and the hydrogen sulfide (stream 29) is sent to the Aqua-Claus plant for sulfur recovery. The gas is cryogenically separated to hydrogen (stream 25) for recycle to the reactor, an LPG product (stream 33), and a synthesis gas. The char from hydrocarbonization and char cooling (stream 47) is yasifled in a Texaco partial oxidation unit to produce makeup hydrogen for hydrocarbonization (stream 38) with the excess hydrogen and carbon monoxide (stream 35) added to the main product gas stream. The remainder of the char (stream 48) is burned in the boiler to produce process heat. The sulfur dioxide is scrubbed from the stack gas (stream 49) in a regenerative absorption system and sent to the Aqua-Claus plant for reduction to elemental sulfur (stream 51). 


\section{IDENTIFICATION OF WASTEWATER STREAMS}

The hydrocarbonization plant has 15 major wastewater streams. The main sources of wastewater are coal storage, hydrocarbonization aqueous product, and ash handling streams. In the Coalcon design, ${ }^{1}$ most of the wastewater is utilized in the plant, including all the organically contaminated water. Although data on the composition of the wastewater streams are lacking, the composition of the various streams has been postulated based on an analysis of similar streams in similar processes.

All organically contaminated aqueous streams are recycled within the process, and a method for destruction or recovery of the organics is provided. Some ash sluicing water overflows the ash pond and enters the river via a percolation bed during periods of very high rainfall (e.g., a 10-year, 24-hr precipitation event). This stream is very low in organic contaminants but mlay contain toxic trace elements; however, it has been shown ${ }^{21}$ that soil used in percolation beds is a very effective sorber of trace elements ( $>95 \%$ retention of trace elements in 5 to $20 \mathrm{ft}$ of soil).

In this design, a sizeable volume $(\sim 130,000 \mathrm{lb} / \mathrm{hr})$ of water is discharged to surface water. This stream contains sollie water treatment wastes, treated cooling tower blowdown, and the effluent from the sanitary waste treatment plant. The main wastewater streams (see Fig. 3.1) of concern to this report are discussed below.

\subsection{Coal Storage Runoff}

Rainwater runoff from coal storage piles (stream 3 ) is a significant water quality hazard. A 90-day supply, or -1.3 million tons of coal, is 
kept in storage. The average rainwater runoff from this 30 to 40 -acre supply is about $530 \mathrm{lb} / \mathrm{hr}$. Water percolating through the pile can react with sulfur-bearing mineral matter by a mechanism not totally unlike that of acidic coal-mine drainage. The sulfuric acid formed in these reactions then dissolves salts from the coal.

In $i$ ts investigation of electric power generation, ${ }^{22}$ the EPA studied drainage from coal storage piles, and Table 4.1 summarizes these results. Plants 6,7 , and 8 used high-sulfur coal and have the most acidic drainage; plants 9, 10 and 11 used a very low-sulfur coal, which resulted in near neutral drainage. The EPA did not report the size of the coal storage piles, the location of the plants, nor the amount of rainfall received during the tests.

Based on this information, it is estimated that the drainage from a coal storage pile using Illinois No, 6 coal would have a pH of 2 to 5 and a total suspended solids concentration count of approximately 100 to $400 \mathrm{mg} / \mathrm{liter}$. Since the drainage is fairly acidic, significant amounts of trace metals (e.g., mercury, cadmium, zinc, arsenic, lead, chromium, copper) are expected to be leached into the water. The concentrations of these metais will probably be higher than the standards set by the U.S. Public Health Service for drinking water and current discharge limits. A more complete discussion of trace elements is found in Sect. 5.2 .

The Coalcon design ${ }^{1}$ calls for the coal pile runoff (stream 3) to be stored and reclaimed as makeup slurry water for the Texaco gasification unit. Recycling the runoff from coal storage routes water with a low $\mathrm{pH}$ and high concentrations of suspended solids and trace elements to 
Table: 4.1. Coal storage-piie drainage discharge concentrations (mg,liter:-

\begin{tabular}{|c|c|c|c|c|c|c|c|c|c|c|c|c|c|c|c|c|c|c|}
\hline Plant & $\mathrm{pH}$ & $\mathrm{BOD}$ & COD & TDS & TSS & $\mathrm{NH}_{3}$ & $\mathrm{NO}_{3}^{-}$ & $P$ & $\begin{array}{c}\text { Total } \\
\text { hard ess }\end{array}$ & $\mathrm{SO}_{4}^{2^{-}}$ & $\mathrm{Cl}^{-}$ & $\mathrm{Al}^{3+}$ & c. & $\mathrm{Cu}$ & $\mathrm{Fe}$ & Mg & $\mathrm{Zn}$ & $\mathrm{Na}$ \\
\hline 1 & 2.8 & 0 & 1080 & 720 & 610 & 0 & 0.3 & & 130 & 525 & 3.6 & & 0 & 1.6 & 0.168 & & 1.6 & 1260 \\
\hline 2 & 2.8 & 0 & 1080 & 720 & $E 10$ & 0 & 0.3 & & $1 \Xi 0$ & 525 & 3.6 & & $c$ & 1.6 & 0.168 & & 1.6 & 1260 \\
\hline 3 & 3 & 10 & 806 & 7,743 & $2 ?$ & 1.77 & 1.9 & 1.2 & 11119 & 5,231 & 481 & & c. 37 & & & 89 & 2.43 & 160 \\
\hline 4 & 4.4 & & 85 & $\equiv, 800$ & 200 & 1.35 & 1.8 & & 1850 & 861 & & & 0.05 & & 0.06 & 174 & 0.006 & \\
\hline 5 & 7.8 & 3 & 1099 & 247 & $3: 302$ & 0.35 & 2.25 & 0.23 & & 133 & 23 & & & & & & 0.08 & \\
\hline $6^{c}$ & 2.7 & & & & & & & & & 6,837 & & & & & 0.368 & & & \\
\hline $7^{c}$ & 2.1 & & & $\angle 8,970$ & 100 & & & & & 19,000 & & 1203 & 15.7 & 1.8 & 4,700 & & 12.5 & \\
\hline $8^{c}$ & 2.8 & & & 44,050 & 95[ & & & & & 21,920 & & 825 & 3.3 & 3.4 & 93,000 & & 23 & \\
\hline$g^{d}$ & 6.7 & & & & & & & & & & & & & & 1.0 & & & \\
\hline $10^{d}$ & 6.6 & & & & & & & & . & . & & & & & 1.05 & & & \\
\hline $11^{d}$ & 6.6 & & & & & & & & & & & & & & 0.9 & & & \\
\hline $\begin{array}{l}\text { Effluent } \\
\quad \text { limits }\end{array}$ & $6-9$ & & & & 35.0 & & & & & & & $\bar{c} .0$ & & & 3.5 & & 0.2 & \\
\hline
\end{tabular}

${ }^{a}$ Values derived from ref. 22, p. 165

${ }^{\mathrm{As}} \mathrm{CaCO}_{3}$.

$c_{p l a n t}$ uses high-sulfur cosl.

$d_{\text {plant uses very low-sulfur coal. }}$

esee columns under "Coal mining," Table 6.1 in this report. 
the gasifier. The organic portion of the waste is utilized in the gasifier as hydrogen production feedstock, and the inorganics ultimately go to the ash pond.

Although the coalcon flowsheet ${ }^{1}$ and other coal conversion schemes are based on coal storage equal to a 90-day supply, it is not clear that such a large supply is needed. Since hydrocarbonization produces a storable product (as opposed to coal-fired power plants), such a plant can provide deliveries from product storage for some time (the coalcon flowsheet ${ }^{1}$ requires a product storage capacity equal to 3 days of production for the SNG, LPG, light and heavy oils, ammonia, and sulfur products) in the event of an interruption of the coal supply. Furthermore, if the plant output is used by an interruptable consumer a smaller amount of coal storage may be used. In any case, the need for some downstream storage is evident since circumstances other than an interruption of the coal supply can cause production to stop. The optimum size of coal and product storage capacities are beyond the scope of this study and will not be discussed further.

\subsection{Coal Pressurization Condensate}

Stream $10(125,000 \mathrm{lb} / \mathrm{hr})$ is the condensate from the steam pressurization section. This steam (stream 20) is produced by contacting liquid water with hot char from the reactor and may be contaminated with phenolics, other organics, ammonia, and hydrogen sulfide. Since there are no available data on the composition of this stream or a similar stream, only an estimation of the composition of the contaminants in stream 10 is possible. The Coalcon flowsheet ${ }^{1}$ shows this stream being sent to the gasifier as char slurry makeup water. 


\subsection{Hydrocarbonization Product Water}

The reactor overhead product from hydrocarbonization contains a significant quantity of water vapor that passes overhead in the product separation fractionator and is condensed and decanted from the hydrocarbon stream. This aqueous stream (stream 19), often known as sour water, is one of the major water quality hazards of coal conversion. Its large flow $(-105,000 \mathrm{lb} / \mathrm{hr})$ and high concentration of contaminants make it an important stream to consider. Although no analys is of either the Coalcon product water stream or a hydrocarbonization process similar to Coalcon has been reported, data are available from similar processes.

U.S. Steel ${ }^{23}$ has reported an analysis of water formed in their Clean Coke Process hydrocarbonizer. This reactor was operated at a temperature of $593^{\circ} \mathrm{C}$, a total pressure of 80 psia $\left(-50 \% \mathrm{H}_{2}\right)$, and yielded $4.5 \%$ product water (based on coal feed). This analysis, shown in Table 4.2, indicates potentially recoverable amounts of phenolics and ammonia.

The FMC Corporation has develuped the COED ${ }^{24}$ process, which is a staged pyrolysis process not drastically dissimilar from hydrocarbonization. In the COED process, the coal-char is heated at successively higher temperatures in a reducing atmosphere. COED produces two productwater streams; an analysis of these streams, ${ }^{25}$ produced by two feedstocks, is shown in Table 4.3. A more dctailed compnunn hreakdown of the major organic species in the first-stage liquor has been reported ${ }^{26}$ and is shown in Table 4.4. Although these two analyses show different concentrations fur phenol, the higher concentrations are probably more representative. 
Table 4.2. Analysis of clean coke hydrocarbonization product water

\begin{tabular}{|c|c|c|}
\hline Component & $\begin{array}{c}\text { Concentration } \\
(\mathrm{mg} / \mathrm{liter})\end{array}$ & $\begin{array}{c}\text { Effluent standards } \\
\text { (mg/liter) }\end{array}$ \\
\hline $\mathrm{CNS}^{-}$ & 1,171 & \\
\hline $\mathrm{CN}^{-}$ & 74 & $0.02-0.1$ \\
\hline $\mathrm{SO}_{4}^{2-}$ & 2,050 & \\
\hline$s^{2-}$ & 562 & $0.02-0.2$ \\
\hline $\mathrm{NH}_{3}$ & 33,320 & $0.8-5.0$ \\
\hline Phenol & 3,200 & \\
\hline o-Cresol & 700 & \\
\hline $\mathrm{m}, \mathrm{p}$-Cresol & 1,500 & $($ tota $])$ \\
\hline Xylenols & 500 & \\
\hline
\end{tabular}

${ }^{a}$ Values deriven from ref. 23, p. 43.

bee columns under "Anticipated regulations," Table 6.1 in this report. 
Table 4.3. Analysis of product water from the COED process ${ }^{a}$

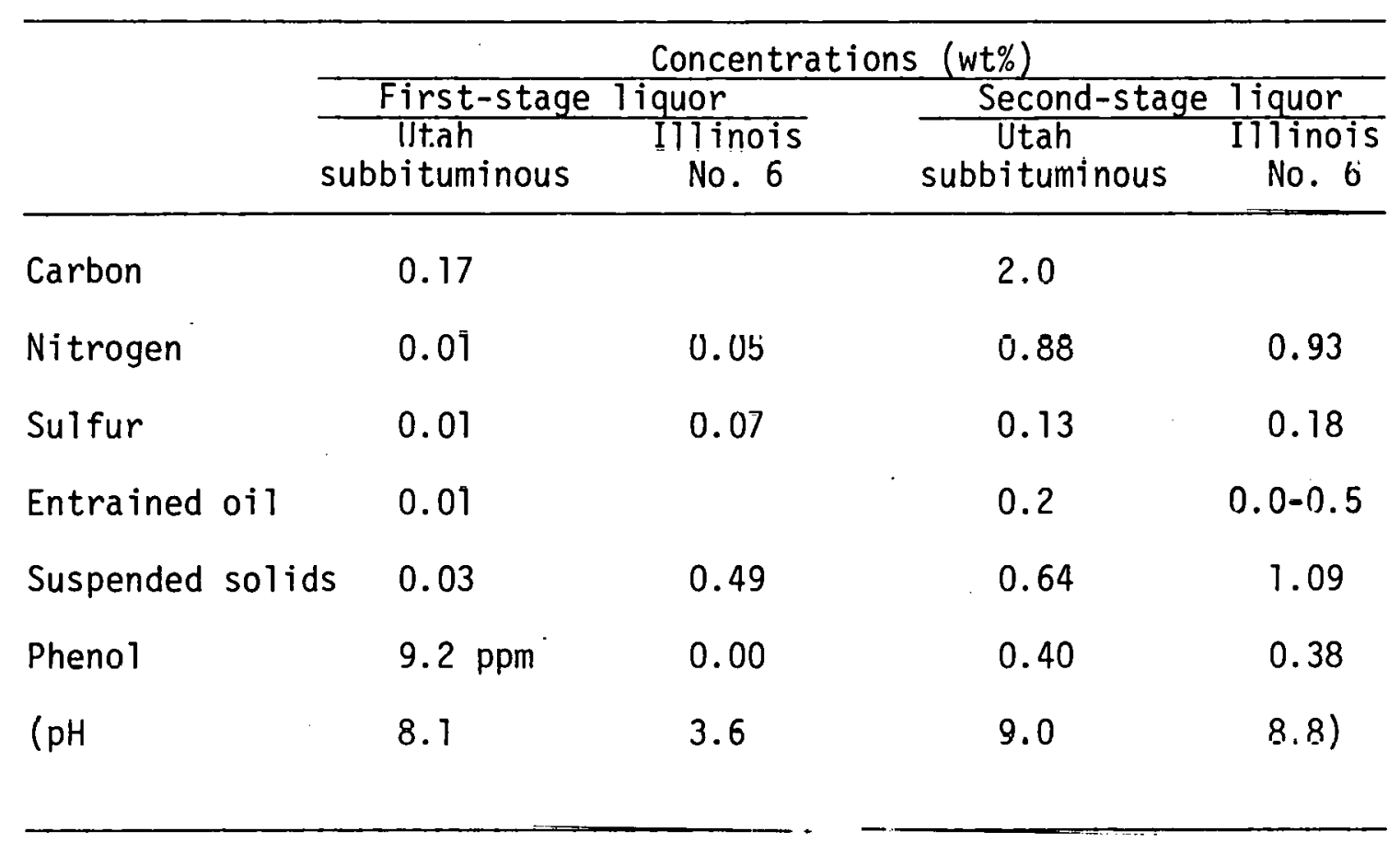

${ }^{a}$ Values dèrqued fruill rect. 26, p. 155. 
Table 4.4. Analysis of first-stage water from the COED process ${ }^{a}$

\begin{tabular}{lc}
\hline \multicolumn{1}{c}{ Compound } & $\begin{array}{c}\text { Concentration } \\
(\mathrm{ppm})\end{array}$ \\
\hline Phenol & 2060 \\
m, p-Cresol & 1830 \\
0-Cresol & 650 \\
Acetic acid & 602 \\
2,5-Dimethylphenol & 217 \\
3,5-Dimethylphenol & 240 \\
3,4-Dimethylphenol & 873 \\
2,6-Dimethylphenol & 30 \\
0-Ethylphenol & 34 \\
2,3-Dimethylphenol & 26 \\
Propionic acid & 94 \\
Butyric acid & 40 \\
Valeric acid & 30 \\
Hexanoic acid & 32 \\
& \\
\hline
\end{tabular}

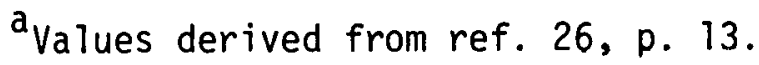


A gasification process called Synthane is being developed at the Pittsburgh Energy Research Center (PERC), and much analytical data are in the literature. ${ }^{26-29}$ Although gasification of coal is fundamentally different from hydrocarbonization, the Synthane process is similar because the coal is fed into free-fall in a hot, hydrogen-rich atmosphere in which the coal is devolatilized. These devolatilization products are probably similar to hydrocarbonization products. Table 4.5 summarizes the Synthane product water analyses performed at PERC ${ }^{27}$ for several different coals. Table 4.6 summarizes a more detailed analys is of organic compounds in the synthane product that was made at ORNL. ${ }^{26}$

Based on these analyses, it is possible to extrapolate the composition of the hydrocarbonization product water. It will have a pH of approximately 8 to 10 , and may be up to $1 \%$ phenolics. Carboxylic acids may be present in concentrations of 500 to $1000 \mathrm{ppm}$ with appreciable cyanate (10 to $200 \mathrm{ppm})$ and thiocyanate (100 to $2000 \mathrm{ppm})$ concentrations. The stream will be rich in ammonia, possibly as much as $3 \%$, with $\mathrm{H}_{2} \mathrm{~S}$ concentrations in the range 200 to $1500 \mathrm{ppm}$ as sulfide. Up to $1 \%$ suspended or entrained insoluble oils and grease may be present. The condensate should be free of solids, since the vapor stream will have passed two cyclone stages and a venturi scrubber. The fines collected in the cyclone will be recycled to the hydrocarbonization reactor or the gasifier. Only the more volatile trace elements (e.g., mercury, arsenic) will be found in the hydrocarbonization product water. These trace elements are discussed in more detail in Sect. 5.2.

The Coalcon flowsheet ${ }^{1}$ shows that the hydrocarbonization product water (stream 19) is sent to a steam stripping column for the recovery 
Table 4.5. Analysis of Synthane product water ${ }^{a}$ for several gasifier feedstocks and comparison with effluent standards (concentration in $\mathrm{mg} / \mathrm{liter}$ )

\begin{tabular}{|c|c|c|c|c|c|c|c|}
\hline Coal & $\begin{array}{l}\text { Illinois } \\
\text { No. } 6 \\
\text { coal }\end{array}$ & $\begin{array}{l}\text { Wyoming } \\
\text { subbituminous } \\
\text { coal }\end{array}$ & $\begin{array}{l}\text { Il inois } \\
\text { char }\end{array}$ & $\begin{array}{l}\text { North } \\
\text { Dakota } \\
\text { lignite }\end{array}$ & $\begin{array}{l}\text { Western } \\
\text { Kentucky } \\
\text { coal }\end{array}$ & $\begin{array}{l}\text { Pittsburgh } \\
\text { steam } \\
\text { coal }\end{array}$ & $\begin{array}{l}\text { Effluent } \\
\text { standards }\end{array}$ \\
\hline Suspended solids & 600 & 140 & 24 & 64 & 55 & 23 & $3-15$ \\
\hline Phenol & 2,600 & 6,000 & 200 & 6,600 & 3,700 & 1,700 & $0.03-0.3$ \\
\hline $\mathrm{COD}$ & 15,000 & 43,000 & 1,700 & 38,000 & 19,000 & 19,000 & $20-350$ \\
\hline Thiocyanate & 152 & 23 & 21 & 22 & 200 & 188 & \\
\hline Cyanide & 0.6 & 0.23 & 0.1 & 0.1 & 0.5 & 0.6 & $0.02-0.1$ \\
\hline $\mathrm{NH}_{3}$ & 8,100 & 9,520 & 2,500 & 7,200 & 10,000 & 11,000 & $0.08-5.0$ \\
\hline Ciloride & 500 & & 31 & & & & 0.2 \\
\hline Carbonate & 6,000 & & & & & & \\
\hline Bicarbonate & 11,000 & & & & & & \\
\hline Total sulfur & 1,400 & & & & & & \\
\hline (pH & 8.6 & 8.7 & 7.9 & 9.2 & 8.9 & 9.3 & $6-9)$ \\
\hline
\end{tabular}

${ }^{a}$ Values derived from ref. 27, p. 3.

bee columns under "Anticipated regulations," Table 6.1 in this report. 
Table 4.6. Major organic constituents of Synthane product watera

\begin{tabular}{|c|c|}
\hline Component & $\begin{array}{c}\text { Concentration } \\
\text { (mg/liter) }\end{array}$ \\
\hline Phenol & 2070 \\
\hline$\underline{m}$, p-Cresol & 1830 \\
\hline$\underline{0}$-Cresol & 670 \\
\hline Acetic acid & 619 \\
\hline 2,5-Dimethylphenol & 248 \\
\hline 3,5-Dimethylphenol & 225 \\
\hline 3,4-Dimethylphenol & 94 \\
\hline 2,6-Dimethylphenol & 44 \\
\hline o-Ethylphenol & 33 \\
\hline 2,3 -llịmęthyl phennl & 32 \\
\hline Propionic acid & 63 \\
\hline Butyric acid & 18 \\
\hline Valeric acid & 10 \\
\hline Hexanoic acid & 16 \\
\hline$\alpha$-Naphthol & 10 \\
\hline B-Naphthul & 32 \\
\hline
\end{tabular}

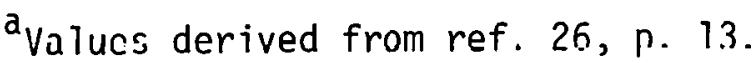


of ammonia and sulfur. Ammonia is recovered from the water for economic reasons, and any sulfur left in the water after stripping is recovered in the treatment of the synthesis gas produced in the gasifier. After stripping, the stream (stream 25) is somewhat larger due to steam condensation, and it contains less $\mathrm{NH}_{3}$ and $\mathrm{H}_{2} \mathrm{~S}$ and is slightly depleted in phenolics.

\subsection{Acid-Gas Removal and Hydrocarbon Separation Recycles}

Stream 23 is a sma 11, aqueous condensate stream formed in the hydrocarbon separation section when the gas stream is cooled to $13^{\circ} \mathrm{C}$. This stream should be free of $\mathrm{H}_{2} \mathrm{~S}$ and $\mathrm{NH}_{3}$ and may contain some light hydrocarbon liquids that passed the earlier recovery steps. The Coalcon flowsheet shows this stream returning to the decanter in the hydrocarbonization section for recovery of any hydrocarbon values.

Stream 27 is formed by regeneration of the activated carbon beds located in the gas outlet of the acid-gas removal section. The beds are designed to scavenge small quantities of sulfur that would be destructive to downstream catalysts, but they also sorb light hydrocarbons and aromatics. The adsorbtion beds are operated semicontinuously, with regeneration when the effluent gas quality begins to decline. For this reason, the quantity of the regeneration wastes (i.e., frequency of regeneration) and the concentration of contaminants depends very strongly on the effectiveness of the upstream gas treatment. Assuming that gas leaving the acid-gas removal section is $50-\mathrm{ppm}_{2} \mathrm{~S}$, the regeneration wastewater may contain up to $0.1 \%$ dissolved $\mathrm{H}_{2} \mathrm{~S}$. The regeneration waste stream probably contains some dissolved light aromatics and some suspended light oils (>5 ppm). The coalcon flowsheet shows recycle of this stream 
to the decanter in the hydrocarbonization section for sulfur recovery and utilization of hydrocarbon values.

\subsection{Methanation Product Water}

Stream 37 is the water stream produced in the methanation section where residual $\mathrm{CO}$ and $\mathrm{CO}_{2}$ are converted to methane by the following reactions.

$$
\begin{aligned}
& \mathrm{CU}_{2}+\mathrm{H}_{2}+\mathrm{CO}+\mathrm{H}_{?} \mathrm{O} \\
& \mathrm{CO}+3 \mathrm{H}_{2} \rightarrow \mathrm{CH}_{4}+\mathrm{H}_{2} \mathrm{O} .
\end{aligned}
$$

Approximately 38,000 1b of water per hour is formed by this reaction. It is anticipated that this stream will be free of contaminants, and one design for a commercial gasification plant ${ }^{30}$ used this water for boiler feed. However, the Coalcon flowsheet does not identify the destination of this stream.

\subsection{Ash Slurrics}

Streams 53 and 42 are the hniler ash and gasificr ash slurries. These streams contain most of the inorganics contained in the coal feed to the system. Although the boiler and gasifier operate quite differently, the ash formed in both operations is similar. The major ash constituents of two samples of Illinois No. 6 coal are shown in Table 4.7. 31 The ash composition is different in two samples from the same scarn, and such differences will probably be more marked in samples from other seams. Sample No. 2 is somewhat anomalous in the high content of iron. In addition to the major ash constituents, all coals have relatively large amounts of many trace elements. Most of the trace-element content of the 
Table 4.7. Major ash compounds ${ }^{\mathrm{a}}$ as percent ash

\begin{tabular}{|c|c|c|}
\hline Illinois No. 6 coal & Sample No. 1 & Sample No. 2 \\
\hline $\mathrm{SiO}_{2}$ & 50.0 & 17.5 \\
\hline $\mathrm{Al}_{2} \mathrm{O}_{3}$ & 22.2 & 9.2 \\
\hline $\mathrm{Fe}_{2} \mathrm{O}_{3}$ & 10.75 & 64.13 \\
\hline $\mathrm{TiO}_{2}$ & 0.94 & 0.44 \\
\hline $\mathrm{CaO}$ & 9.00 & 4.05 \\
\hline $\mathrm{MgO}$ & 1.14 & 0.38 \\
\hline $\mathrm{Na}_{2} \mathrm{O}$ & 0.35 & 0.26 \\
\hline $\mathrm{K}_{2} \mathrm{O}$ & 2.20 & 0.97 \\
\hline $\mathrm{SO}_{3}$ & 1.56 & 1.84 \\
\hline $\begin{array}{l}\text { Ash content of coal } \\
(\% \text { dry coal })\end{array}$ & 14.36 & 9.59 \\
\hline
\end{tabular}

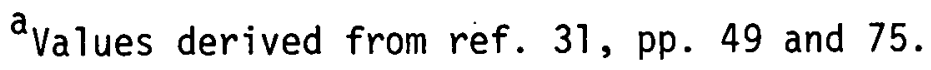


feed coal ultimately goes to the ash slurries and the ash pond, either in colution or in the solid phase. Table 4.7 shows the results of an analysis of coal ash formed in an air atmosphere at $950^{\circ} \mathrm{C}$, which is similar to the ash formed in a boiler furnace or partial oxidation gasifier.

One study concerned with leaching of ash materials was done by the Radian Corporation ${ }^{21}$ for the Electric Power Research Institute. This report presents data from batch ash-leaching experiments using ash obtained from five power plants and ash-pond-water analys is for four power plants.

The ash leaching data were obtained by contacting a mixture of 20-wt \% ash and deionized water for $24 \mathrm{hr}$ in a closed container. Table 4.8 shows a summary of the ash leachate trace-element results. The major species in the ash leachate are shown in Table 4.9. The pH of the leaching solution can alter equilibrium trace-element leaching data. The Radian report also gives data on the analyses of ash pond water, and coal and makeup water for three of the plants studied. Table 4.10 summarizes those results. Additional information on the coal properties used in the tests is given in Table 4.11 .

Farnsworth et al. ${ }^{32}$ have published an analysis of the ash sluicing water from a commercial Koppers-Totzek (K-T) gasifier, which is an entrained flow, slagging gasifier that operates at atmospheric pressure. Although the Texaco unit in the Coalcon process is different from the K-T gasifier, the ash sluicing water should be of similar composition. Table 4.12 shows the analys is of ash sluicing water to and from the gasifier. 
Table 4.8. Comparison of equilibrium concentrations of trace elements in coal-ash leachate and effluent standards

\begin{tabular}{|c|c|c|c|c|c|c|}
\hline & \multicolumn{5}{|c|}{ Station } & \multirow{2}{*}{$\begin{array}{l}\text { Effluent } \\
\text { standards }\end{array}$} \\
\hline & $T$ & 2 & 3 & 4 & 5 & \\
\hline $\begin{array}{l}\text { Bottom ash, } \\
\text { wt } \%\end{array}$ & 20 & 20 & 20 & 50 & 100 & \\
\hline $\begin{array}{l}\text { Precipitator ash, } \\
\text { wt } \%\end{array}$ & 80 & 80 & 80 & 50 & & \\
\hline $\mathrm{pH}$ & 12.5 & 9.5 & 12.2 & 12.0 & 8.2 & $6-9$ \\
\hline \multicolumn{7}{|l|}{ Element (mg/liter) } \\
\hline $\begin{array}{l}\mathrm{Sb} \\
\mathrm{As} \\
\mathrm{Ba} \\
\mathrm{Be} \\
\mathrm{B} \\
\mathrm{Cd} \\
\mathrm{Cr} \\
\mathrm{F} \\
\mathrm{Ge} \\
\mathrm{Hg} \\
\mathrm{Pb} \\
\mathrm{Mn} \\
\mathrm{Mo} \\
\mathrm{Ni} \\
\mathrm{Se} \\
\mathrm{V} \\
\mathrm{Zn} \\
\mathrm{Cu}\end{array}$ & $\begin{array}{c}0.006 \\
<0.002 \\
40 \\
0.003 \\
0.03 \\
<0.001 \\
<0.001 \\
2.3 \\
<0.01 \\
0.0006 \\
0.0068 \\
<0.002 \\
0.047 \\
<0.05 \\
0.0199 \\
<0.1 \\
0.038 \\
<0.005\end{array}$ & $\begin{array}{l}0.018 \\
0.084 \\
<0.3 \\
0.00064 \\
16.9 \\
0.0025 \\
0.21 \\
1.4 \\
<0.01 \\
0.0005 \\
0.0027 \\
<0.002 \\
0.052 \\
0.015 \\
<0.0005 \\
<0.1 \\
0.025 \\
0.031\end{array}$ & $\begin{array}{c}0.033 \\
0.015 \\
<0.3 \\
0.0007 \\
0.21 \\
<0.01 \\
0.11 \\
2.0 \\
<0.01 \\
0.015 \\
0.024 \\
<0.002 \\
0.05 \\
0.025 \\
0.033 \\
<0.1 \\
0.19 \\
0.092\end{array}$ & $\begin{array}{c}0.022 \\
0.072 \\
<0.3 \\
0.001 \\
1.1 \\
<0.001 \\
1.0 \\
17.3 \\
<0.01 \\
0.0003 \\
0.0043 \\
<0.002 \\
0.69 \\
<0.05 \\
0.47 \\
<0.2 \\
<0.005 \\
0.013\end{array}$ & $\begin{array}{l}0.0087 \\
0.006 \\
<0.3 \\
0.00026 \\
0.048 \\
0.0011 \\
0.14 \\
1.4 \\
<0.01 \\
0.0003 \\
0.0063 \\
<0.002 \\
0.010 \\
0.46 \\
<0.0005 \\
<0.1 \\
0.0175 \\
0.015\end{array}$ & $\begin{array}{l}0.25 \\
2.0 \\
\\
0.15 \\
0.1-1.0 \\
14 \\
0.0005 \\
0.1 \\
1.0 \\
1.0 \\
1.0 \\
1.0 \\
1.0\end{array}$ \\
\hline
\end{tabular}

a Values derived from ref. 21, p. 20.

bee columns under "Anticipated regulations," Table 6.1 in this report. 
Table 4.9. Ions present in ash sluicing waters ${ }^{a}$

\begin{tabular}{lc}
\hline Species & Concentration (mg/liter) \\
\hline $\mathrm{Ca}$ & 900 \\
$\mathrm{Na}$ & 72 \\
$\mathrm{~K}$ & 4 \\
$\mathrm{Mg}$ & 1 \\
$\mathrm{Total} \mathrm{Fe}^{2}$ & 1 \\
$\mathrm{OH}$ & 800 \\
$\mathrm{CO}_{3}$ & 70 \\
$\mathrm{Cl}^{2}$ & 10 \\
$\mathrm{SO}_{4}$ & 10 \\
$\mathrm{NO}_{3}$ & 2 \\
\hline
\end{tabular}

${ }^{a}$ Values derived from ref. 21, p. 28. 
Table 4.10. Trace-element fate ${ }^{a}$ for caal-fired steam generating plants

\begin{tabular}{|c|c|c|c|c|c|c|c|c|c|c|c|c|c|c|c|}
\hline \multirow[b]{2}{*}{ Element } & \multicolumn{5}{|c|}{ Station No. 2} & \multicolumn{5}{|c|}{ Station No. 3} & \multicolumn{5}{|c|}{ Station No. 4} \\
\hline & $\begin{array}{r}\text { Coal } \\
(\mathrm{ppm})\end{array}$ & $\begin{array}{l}\text { Bottom } \\
\text { ash } \\
\text { (ppm) }\end{array}$ & $\begin{array}{c}\text { Fly } \\
\text { ash } \\
(\mathrm{ppm})\end{array}$ & $\begin{array}{l}\text { Ash } \\
\text { pond } \\
\text { liquor } \\
(\mathrm{mg} / \mathrm{l})\end{array}$ & $\begin{array}{r}\text { Makeup } \\
\text { water } \\
(\mathrm{mg} / \mathrm{l})\end{array}$ & $\begin{array}{l}\text { Coal } \\
\text { (ppm) }\end{array}$ & $\begin{array}{l}\text { Bottom } \\
\text { ash } \\
\text { (ppm) }\end{array}$ & $\begin{array}{c}\mathrm{Fly} \\
\text { ash } \\
(\mathrm{ppm})\end{array}$ & $\begin{array}{c}\text { Ash } \\
\text { pond } \\
\text { liquor } \\
(\mathrm{mg} / \mathrm{l})\end{array}$ & $\begin{array}{r}\text { Makeup } \\
\text { water } \\
(\mathrm{mg} / \mathrm{l})\end{array}$ & $\begin{array}{c}\overline{C o a l} \\
(\mathrm{ppm})\end{array}$ & $\begin{array}{l}\text { Botton } \\
\text { ash } \\
\text { (ppm) }\end{array}$ & $\begin{array}{c}\text { Fly } \\
\text { ash } \\
\text { (ppm) }\end{array}$ & $\begin{array}{l}\text { Ash } \\
\text { pond } \\
\text { liquor } \\
(\mathrm{mg} / \mathrm{l})\end{array}$ & $\begin{array}{r}\text { Makeup } \\
\text { water } \\
(\mathrm{mg} / \mathrm{l})\end{array}$ \\
\hline $\begin{array}{l}\mathrm{Sb} \\
\mathrm{As} \\
\mathrm{Ba} \\
\mathrm{Be} \\
\mathrm{B} \\
\mathrm{Cd} \\
\mathrm{Cr} \\
\mathrm{F} \\
\mathrm{Ge} \\
\mathrm{Hg} \\
\mathrm{Pb} \\
\mathrm{Mn} \\
\mathrm{Mo} \\
\mathrm{Ni} \\
\mathrm{Se} \\
\mathrm{V} \\
\mathrm{Zn} \\
\mathrm{Cu}\end{array}$ & $\begin{array}{c}0.34 \\
8.7 \\
100 \\
1.3 \\
36.5 \\
0.05 \\
1.2 \\
193 \\
2.9 \\
0.199 \\
1.4 \\
60.4 \\
1.3 \\
12.9 \\
2.24 \\
<16 \\
68.6 \\
22.2\end{array}$ & $\begin{array}{c}1.3 \\
8.3 \\
700 \\
4.7 \\
80.0 \\
0.41 \\
14.7 \\
72.2 \\
1.0 \\
0.215 \\
12 \\
281 \\
7.5 \\
66.8 \\
0.495 \\
<98 \\
<49 \\
141\end{array}$ & $\begin{array}{c}1.5 \\
74 \\
700 \\
7.5 \\
274 \\
1.4 \\
3.6 \\
83.9 \\
12.1 \\
<0.010 \\
17 \\
242 \\
5.4 \\
75.1 \\
3.27 \\
<100 \\
102 \\
113\end{array}$ & $\begin{array}{c}0.005 \\
0.02 \\
<0.3 \\
0.003 \\
0.233 \\
0.0005 \\
<0.0008 \\
0.35 \\
0.02 \\
0.001 \\
0.02 \\
0.02 \\
0.004 \\
<0.01 \\
0.0044 \\
<0.10 \\
0.02 \\
<0.004\end{array}$ & $\begin{array}{c}0.008 \\
=0.0004 \\
=0.3 \\
0.003 \\
0.112 \\
0.0004 \\
0.001 \\
0.18 \\
<0.1 \\
<0.001 \\
0.02 \\
0.016 \\
0.02 \\
0.0079 \\
0.0003 \\
<0.10 \\
0.09 \\
40.004\end{array}$ & $\begin{array}{c}0.82 \\
3.5 \\
100 \\
2.1 \\
62.1 \\
0.30 \\
3.4 \\
144 \\
4.4 \\
0.212 \\
4.3 \\
41.5 \\
0.39 \\
18.7 \\
3.15 \\
<13 \\
68.1 \\
28\end{array}$ & $\begin{array}{c}0.72 \\
8.0 \\
750 \\
7.9 \\
120 \\
0.86 \\
11.0 \\
61.0 \\
1.8 \\
0.056 \\
4.9 \\
297 \\
5.4 \\
101 \\
0.287 \\
<100 \\
343 \\
112\end{array}$ & $\begin{array}{c}2.5 \\
56.6 \\
750 \\
13.1 \\
392 \\
5.3 \\
28.0 \\
210 \\
25.1 \\
0.146 \\
27 \\
273 \\
5.9 \\
108 \\
14.7 \\
<25 \\
854 \\
59\end{array}$ & $\begin{array}{c}0.003 \\
0.003 \\
<0.3 \\
0.0004 \\
0.47 \\
0.0001 \\
<0.0006 \\
0.43 \\
0.02 \\
0.0022 \\
0.03 \\
0.004 \\
0.04 \\
<0.015 \\
0.0088 \\
<0.2 \\
0.035 \\
0.007\end{array}$ & $\begin{array}{l}<0.001 \\
0.004 \\
<0.3 \\
0.0004 \\
0.019 \\
0.0009 \\
0.003 \\
0.90 \\
0.02 \\
0.0014 \\
0.04 \\
0.06 \\
0.03 \\
<0.015 \\
0.00085 \\
<0.2 \\
0.13 \\
0.026\end{array}$ & $\begin{array}{c}0.08 \\
0.87 \\
440 \\
0.29 \\
37.7 \\
0.11 \\
1.8 \\
78.5 \\
0.48 \\
0.131 \\
0.15 \\
26.2 \\
0.87 \\
3.67 \\
0.93 \\
<13 \\
16.2 \\
5.2\end{array}$ & $\begin{array}{c}<1.0 \\
4.4 \\
5600 \\
0.40 \\
83.2 \\
1.1 \\
15.6 \\
44.6 \\
<0.1 \\
<0.010 \\
1.0 \\
56.7 \\
3.2 \\
14.5 \\
0.14 \\
<100 \\
<8.0 \\
68\end{array}$ & $\begin{array}{c}4.4 \\
61 \\
15,000 \\
5.2 \\
1,040 \\
4.2 \\
8.9 \\
2,880 \\
9.2 \\
0 \quad<0.010 \\
4.0 \\
374 \\
12 \\
92.9 \\
16.4 \\
<100 \\
386 \\
238\end{array}$ & $\begin{array}{l}0.007 \\
0.004 \\
<0.3 \\
0.002 \\
0.41 \\
0.0001 \\
0.004 \\
0.43 \\
<0.1 \\
<0.001 \\
0.018 \\
0.10 \\
0.012 \\
0.078 \\
0.0030 \\
<0.2 \\
0.12 \\
0.090\end{array}$ & $\begin{array}{c}<0.002 \\
0.006 \\
<0.3 \\
0.001 \\
0.25 \\
<0.0001 \\
0.09 \\
2.72 \\
<0.1 \\
0.013 \\
0.02 \\
0.19 \\
0.01 \\
0.16 \\
0.0017 \\
<0.2 \\
0.40 \\
0.16\end{array}$ \\
\hline
\end{tabular}

avalues derived from ref. 21 , pp. I-27-29, I-33, I-34. 
Table 4.11. Coal analysis from Radian ${ }^{\mathrm{a}}$ study

\begin{tabular}{cccc}
\hline Station & $\begin{array}{c}\text { Heating value } \\
(\text { Btu/lb dry coal) }\end{array}$ & $\begin{array}{c}\text { Ash content } \\
(\text { wt } \%)\end{array}$ & $\begin{array}{c}\text { Sulfur content } \\
(\text { wt } \%)\end{array}$ \\
\hline 1 & 9,250 & 10 & 0.4 \\
2 & 10,000 & 16 & 4.0 \\
3 & 10,000 & 25 & 4.3 \\
4 & 9,500 & 10 & 4.0 \\
5 & 9,000 & 25 & 5.2 \\
\hline
\end{tabular}

${ }^{a}$ Values derived from ref. 21, p. I-27. 
Table 4.12. Comparison of ash sluicing water from a Koppers-Totzek gas ifjera with effluent standards $b$

\begin{tabular}{|c|c|c|c|}
\hline Component & $\begin{array}{c}\text { Water to } \\
\text { gasifier } \\
(\mathrm{mg} / \mathrm{l})\end{array}$ & $\begin{array}{c}\text { Water from } \\
\text { gasifier } \\
(\mathrm{mg} / \mathrm{l})\end{array}$ & $\begin{array}{l}\text { Effluent } \\
\text { standards b } \\
(\mathrm{mg} / \mathrm{l})\end{array}$ \\
\hline $\mathrm{CaO}$ & 78 & 101 & \\
\hline MgO & 97 & 167 & \\
\hline$=\mathrm{Na}$ & 17.5 & 17.5 & \\
\hline K & 5.6 & 8.8 & \\
\hline $\mathrm{Zn}$ & 0.01 & 0.03 & 1.0 \\
\hline $\mathrm{Fe}$ & 0.05 & 0.22 & 1.0 \\
\hline $\mathrm{NH}_{4}$ & 0.32 & 157 & $0.8-5.0$ \\
\hline $\mathrm{NO}_{2}$ & 0.02 & 0.13 & \\
\hline $\mathrm{NO}_{3}$ & 58.2 & 3.32 & \\
\hline $\mathrm{PO}_{4}$ & 1.89 & 0.81 & \\
\hline $\mathrm{Cl}$ & 18 & 85 & 0.1 \\
\hline $\mathrm{SO}_{4}$ & 42 & 216 & \\
\hline $\mathrm{CN}$ & 0.26 & 0.52 & $0.02-0.1$ \\
\hline$C O D$ & 14 & 18 & $20-350$ \\
\hline $\mathrm{SiO}_{2}$ & 14.8 & 16.0 & \\
\hline $\operatorname{TSS}^{\bar{C}}$ & 14 & 4612 & $3-15$ \\
\hline Cu․ & 0.01 & $\underline{0.01}$ & 1.․․․ \\
\hline$(\mathrm{pH}$ & 8.8 & 8.8 & $6-9)$ \\
\hline
\end{tabular}

${ }^{a}$ Values derived from ref. 32, p. 126.

${ }^{b}$ See columns under "Anticipated regulations," Table 6.1 in this report.

${ }^{c}$ Total suspended solids. 
It is estimated that the ash sluicing water will contain a large amount (6000 to $200,000 \mathrm{mg} / 1$ iter) of suspended solids and have a pH of 8 to 13. The concentration of ammonia, phenols, and oils will be near zero. The water will contain many trace elements in varying concentrations, some of which may be too high for discharge to local surface waters.

\subsection{Boiler and Cooling Tower Blowdown}

The coalcon plant utilizes two sources of boiler blowdown. The water jacket of the Texaco gasifier is the source of a small blowdown (stream 43), and stream 57 is blowdown from the char furnace boiler. Blowdown refers to a "draw-off" from a recirculating stream to keep the amount of dissolved solids low enough to prevent scaling and corrosion of heat exchange tubes.

Some data on the nature of pollutants have been reported in a study made for the EPA. 22 These data represent "grab" samples from several streams of three different petroleum rcfineries, but this information has limited usefulness. Table 4.13 shows the pollutant concentrations of the boiler and cooling tower blowdown for the three refineries studied. The boiler blowdown is slightly basic and only slightly contaminated with process filurds. The coalcon fluwsheel! calls for the boiler blowdown to be utilized as a portion of the cooling tower makeup water.

Table 4.13 also shows that the cooling tower blowdown (stream 59) will be similar to the boiler blowdown. Process fluids can enter the cooling water via leaks in heat exchange equipment; when these contaminants are stripped out of the cooling tower, an air pollution 
Table 4.13. Analyses of refinery wastewater ${ }^{a}$

\begin{tabular}{|c|c|c|c|c|c|c|c|c|c|c|c|c|c|c|c|c|}
\hline \multirow{3}{*}{$\frac{\text { Sampling point }}{\text { Boiler blowdown }}$} & \multirow{3}{*}{$\frac{\text { Refinery }}{\text { A }}$} & \multicolumn{15}{|c|}{ Sample No. } \\
\hline & & \multicolumn{3}{|c|}{$\mathrm{CoD}(\mathrm{mg} / \mathrm{liter})$} & \multicolumn{3}{|c|}{ Sulfide(mg/liter) } & \multicolumn{3}{|c|}{ Ammonia(mg/liter) } & \multicolumn{3}{|c|}{ Phenol(mg/liter) } & 1 & $\mathrm{pH}$ & 3 \\
\hline & & 72 & 76 & 98 & $<0.1$ & $<0.1$ & $<0.1$ & 0.7 & 0.5 & 0.7 & & & 0.01 & 11.5 & 11.6 & 11.8 \\
\hline Boiler blowdown & B & 148 & 156 & 108 & $<0.1$ & $<0.1$ & $<0.1$ & 1.2 & 1.05 & 1.20 & $T^{b}$ & 1.2 & $T^{b}$ & 11.3 & 11.0 & 10.5 \\
\hline Boiler blowdown & c & 453 & 615 & 970 & $<0.1$ & $<0.1$ & $<0.1$ & 45 & 40 & 43 & 0.34 & 0.20 & 0.15 & 10.4 & 10.8 & 10.7 \\
\hline $\begin{array}{l}\text { Catalytic cracker cooling } \\
\text { tower blowdown }\end{array}$ & A & 96 & 153 & 205 & $<0.1$ & $<0.1$ & $<0.1$ & 79 & 80 & 80 & & & $T^{b}$ & 6.5 & 6.1 & 6.3 \\
\hline $\begin{array}{l}\text { Catalytic cracker cooling } \\
\text { towe: return }\end{array}$ & $\mathbf{B}$ & 74 & 156 & 54 & $<0.1$ & $<0.1$ & $<0.1$ & 0.6 & 1.25 & 3.0 & 0.05 & 0.08 & $T^{b}$ & 6.2 & 7.7 & 6.7 \\
\hline $\begin{array}{l}\text { Petroleum conderiser cooling } \\
\text { towe- blowdown }\end{array}$ & B & 148 & 129 & 72 & $<0.1$ & $<0.1$ & $<0.1$ & 6 & 8 & 8.5 & 0.20 & $T^{b}$ & $T^{b}$ & 6.5 & 8.0 & 6.9 \\
\hline $\begin{array}{l}\text { Distillation cooling tower } \\
\text { blowdown }\end{array}$ & c & $<0.1$ & 28 & 20 & $<0.1$ & $<0.1$ & $<0.1$ & 20 & 30 & 40 & $<0.1$ & $<0.1$ & $<0.1$ & 6.8 & 6.8 & 7.3 \\
\hline $\begin{array}{l}\text { Catalytic cracker cooling } \\
\text { tower blowdown }\end{array}$ & $c$ & 10 & 9 & 10 & $<0.1$ & $<0.1$ & $<0.1$ & 22 & 35 & 38 & $<0.1$ & $<0.1$ & $<0.1$ & 6.4 & 7.7 & 7.2 \\
\hline $\begin{array}{l}\text { Alkylation cooling tower } \\
\text { blowdown }\end{array}$ & C & $<0.1$ & 18 & 20 & $<0.1$ & $<0.1$ & $<0.1$ & 35 & 40 & 4.5 & $<0.1$ & $<0.1$ & $<0.1$ & 6.1 & 4.3 & 6.4 \\
\hline
\end{tabular}

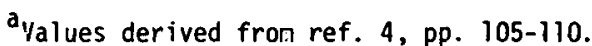

${ }^{b}$ Trace. 
problem results. A study by the U.S. Public Health Service ${ }^{33}$ states that hydrocarbon emissions from cooling towers at petroleum refineries average 9 1b/day for each 1000 gal per minute of cooling water circulated. The Coalcon design ${ }^{1}$ calls for circulation of $-311,000 \mathrm{gal}$ of cooling water per minute; on this basis, one may estimate a hydrocarbon emission from the cooling tower to the atomosphere of $28001 \mathrm{~b} /$ day. Since the source of the data in Table 4.13 does not specify whether the cooling water samples are taken before or after the cooling tower, the values in that table may not represent the true organic concentrations in the cooling water. This is an area in which the few data that exist should be studied more thoroughly. In the Coalcon design, 1 the cooling tower blowdown (stream 59) is coagulated and settled, sent to an ion exchange operation, and then discharged to the river. The ion exchange treatment is used to recover valuable chromate compounds that are added to the cooling water to prevent fouling of heat exchangers by microrganisms.

\subsection{Water Treatment Wastes}

The water treatment for process and potable' water produces two waste streams. These streams are similar to those that are handled routinely in most petroleum and chemical plants as well as municipal water plants. Water from the river (stream 62) is mixed with alum, lime, and polyelectrolytes in the flocculator; it is agitated to form a slurry of precipitated minerals from the water and residual solids from the river. This slurry is sent to a clarifier that separates the stream into a clear overflow and an underflow (stream 66) which contains the solids formed in the flocculator. In its study of coal fired power plants, the EPA 22 has studied water treatment wastes; Table 4.14 is a 
Table 4.14. Characterization of water treatment wastes ${ }^{a}$

\begin{tabular}{lrr}
\hline & $\begin{array}{c}\text { Mean } \\
\text { (mg/liter) }\end{array}$ & $\begin{array}{c}\text { Standard deviation } \\
\text { (mg/liter) }\end{array}$ \\
\hline $\begin{array}{l}\text { Clarification underflow } \\
\mathrm{TSS}^{\mathrm{b}}\end{array}$ & 25,213 & 53,060 \\
$\mathrm{Fe}$ & 352 & 572 \\
& & \\
Ion exchange waste & & \\
$\mathrm{TDS}^{\mathrm{C}}$ & 7,408 & 11,550 \\
$\mathrm{SO}_{4}{ }^{2-}$ & 2,085 & 3,859 \\
$\mathrm{Cl}^{-}$ & 1,708 & 4,603 \\
$\mathrm{Na}^{+}$ & 3,112 & 6,448 \\
$\mathrm{NH}_{3}$ & 558 & 1,572 \\
& & \\
\hline
\end{tabular}

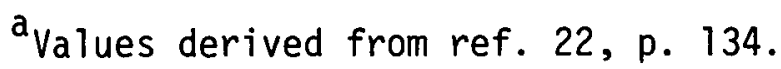

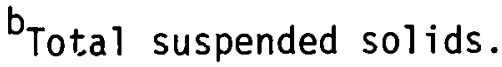

'Total dissolved solids.' 
summary of the EPA findings. The underflow has a high solids content consisting primarily of dissolved and suspended solids from the river. The underflow is also expected to have a high $\mathrm{pH}$, since flocculation and clarification using lime works best at a pH of 9 to $12 .^{34,35}$ In the Coalcon flowsheet, the clarifier underflow is sent to the ash pond as ash sluicing makeup.

The clear overflow from the clarifier is treated in an ion exchange bed to reduce the mineral content of the water. The ion exchange bed is periodically regenerated, producing a small ion exchange waste stream (stream 67). Table 4.14 also shows the EPA findings for ion exchange wastes from water treatment plants for coal-fired power plants. In the Coalcon design, 'the ion exchange wastes are sent to the holding pond and then discharged to surface waters. It is not clear whether this water is of sufficient quality to be discharged; more likely, the ion exchange wastes will need to be sent to the ash pond.

\subsection{Plant Runuff and Washlown}

The water pollution potential of rainwater runoff from plant grounds and washdown of process areas is difficult to quantify. The rainwater runoff may contain suspended oils and dissolved phenols, as well as suspended solids. These contaminants are expected to be dilute, but this water probably cannot be discharged directly to surface waters. The Coalcon design ${ }^{1}$ assumes that $5600 \mathrm{ft}^{2}$ of process area will require periodic washdown for health and safety reasons. This washdown will produce a fairly small waste stream similar to the contaminated rainwater runoff. Coalcon proposes to reclaim the rainwater runoff from plant 
grounds and process area washdown streams by feeding it to the Texaco gasifier as char-slurry makeup water.

\section{MAJOR CONTAMINANTS}

From the preceeding descriptions of the wastewater streams found in a coal conversion facility, it is assessed that the major classes of contaminants present are phenolics, trace elements, and polynuclear aromatic hydrocarbons (PNA). These three groups will have the greatest impact on the type (or types) of control technology to be utilized. Although it is obvious that little more than generalizations can be made concerning which contaminants will be present without actually analyzing the wastewater, the types and quantities of these materials should be investigated.

\subsection{Phenols}

Any aqueous stream contacting coal or one of the various organic streams contains a variety of organics, predominantly phenols. However, as indicated under the various wastewater streams previously descrihed, the stream containing the largest quantity of phenols is the hydrocarbonization product water. Tables 4.2 to 4.6 show the large variety of phenolic compounds found in coal conversion wastewater and indicate that the anticipated amount of phenols will be significant, with concentrations in the 2000 to $6000-p p m$ range.

It is apparent from these tables that phenol removal efficiencies of $99.9 \%$ are not adequate to achieve the anticipated effluent regulations for total phenol of 30 to $300 \mathrm{ppb}$. The recommended level of 
phenol in drinking water is even lower at $1 \mathrm{ppb}$. Phenols are highly toxic, and this toxicity is increased when chlorine is added to the water, as is the case with most wastewater treatment facilities. Concentrations below $100 \mathrm{ppb}$ can cause undesirable tastes and odors, and amounts of $1 \mathrm{ppb}$ can impart objectionable tastes following marginal chlorination. 36

The large amount of phenolics present will not be all phenol. Those wastewater streams for which a breakdowii is avaliable (rables $4 . \overline{2}$, 4.4 , and 4.6 ) indicate that phenol makes up 35 to $54 \%$ of the total, cresols are 37 to $48 \%$, and xylenols are 8 to $23 \%$. Not included in these analyses were the dihydric phenols (catechol, resorcinal, etc.), or the trihydric phenols (phloroglucinal, pyrogellal, etc.). These were either not present or were present at extremely low levels; Tables 4.4 and 4.6 indicate they were not expected in the samples and therefore were not included in reference standards.

The above variety in the type of phenolic compounds present is often ignored and the total amount is summarized as phenol, but the differences are important in an evaluation of any kind of wastewater cleanup technology to be employed. Solvent extraction methods such as "Phenolsolvan" tend to renew all the phenolics, thus producing a "phenol" product that is really a mixture of compounds. Additional (and often expensive) separation steps may then be required to produce a pure, economically valuable phenol product.

Similarly, in phenol degrading biological oxidation units, performance varies with the type of phenolic compounds present. Chambers et al. ${ }^{37}$ investigated the biological oxidation of various 
phenols by phenol-adapted bacteria. They found that the mono- and dihydric phenols, with the exception of the xylenols, were easily oxidized, and the trihydric phenols were very resistant to degradation by these bacteria.

It is obvious that the type of phenolic compounds present may determine the type and degree of wastewater treatment that is required. Although future regulations will probably group all phenolic compounds together, as determined by some standard analytical technique, it will be important to completely characterize the phenolic compounds that may be present.

\subsection{Trace Elements}

In recent years, the public has been concerned about the release of trace elements, primarily heavy metals and halogens, into the environment. All coals contain many trace elements in varying concentrations. Due to the large throughput of coal, sizeable quantities of trace elements can potentially be released to the environment from coal conversion plants. The occurrence of trace elements in the more common coals is well documented. $31,38,39$ Tables 5.1 and 5.2 summarize the content of trace and minor elements of Illinois No. 6 coal. ${ }^{38}$ These tables show that the trace and minor elements must not be discharged directly to the environment, but must be disposed of in an environmentally acceptable manner.

Although it is not now possible to use data such as those in Tables 5.1 and 5.2 to accurately predict the fate of the trace and minor elements in a coal conversion process, several studies have been 
Table 5.1. Trace-element content of Illinois No. $6 \mathrm{coa} 7^{\mathrm{a}}$ and comparison with effluent standardsb

\begin{tabular}{|c|c|c|c|c|}
\hline \multirow[b]{2}{*}{ Element } & \multicolumn{2}{|c|}{ Av conc in coal } & \multirow{2}{*}{$\begin{array}{l}\text { Throughput } \\
\text { (1b/day) }\end{array}$} & \multirow{2}{*}{$\begin{array}{c}\text { Effluent standards } \\
\text { (1b/day) }\end{array}$} \\
\hline & $\mathrm{ppm}$ & $1 \mathrm{~b} / 10^{3}$ tons & & \\
\hline As & 7.6 & 15.2 & 228 & 3.6 \\
\hline B & 129.0 & 258.0 & 3870 & \\
\hline $\mathrm{Be}$ & 1.6 & 3.1 & 48 & \\
\hline $\mathrm{Br}$ & 15.4 & 30.7 & 462 & \\
\hline $\mathrm{Cd}$ & 3.9 & 7.8 & 117 & 2.1 \\
\hline Co & 8.2 & 16.4 & 246 & \\
\hline $\mathrm{Cr}$ & 16.0 & 32.1 & 480 & $1.5-15$ \\
\hline $\mathrm{Cu}$ & 14.8 & 29.6 & 444 & 15 \\
\hline $\mathrm{F}$ & 58.6 & 117.0 & 1758 & 210 \\
\hline Ga & 3.1 & 6.3 & 93 & \\
\hline $\mathrm{Ge}$ & 5.9 & 11.8 & 177 & \\
\hline $\mathrm{Hg}$ & 0.18 & 0.36 & 5.4 & 0.006 \\
\hline $\mathrm{Mn}$ & 53.6 & 107.0 & 1608 & 15 \\
\hline Mo & 9.0 & 18.0 & 270 & \\
\hline $\mathrm{Ni}$ & 22.2 & 44.4 & 666 & 15 \\
\hline $\mathrm{p}$ & 43.6 & 87.2 & 1308 & \\
\hline $\mathrm{Pb}$ & 28.6 & 57.1 & 858 & 1.5 \\
\hline $\mathrm{Sb}$ & 1.0 & 1.9 & 30 & \\
\hline $\mathrm{Se}$ & 2.0 & 4.7 & 60 & 15 \\
\hline Sn & 4.2 & 8.4 & 126 & \\
\hline V & 33.4 & 66.8 & 1002 & \\
\hline $\mathrm{Zn}$ & 450.0 & 900.0 & 13500 & 15 \\
\hline $\mathrm{Zr}$ & 54.8 & 110.0 & 1644 & \\
\hline
\end{tabular}

${ }^{a}$ Values derived from ref. 38 , pp. 7-10.

Wastewater effluent standards and 15,000 tnns of coal feed per day. See culumns under "Anticipated regulations," Table 6.1 in this report.

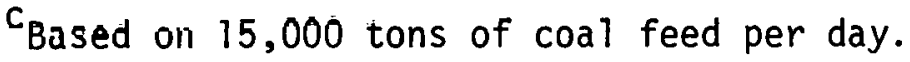


Table 5.2. Minor element content of Illinois No. $6 \mathrm{coal}^{\mathrm{a}}$

\begin{tabular}{ccc}
\hline Element & $\begin{array}{c}\text { Av conc in coal } \\
(\%)\end{array}$ & $\begin{array}{c}\text { Throughput } \\
(103 \text { ib/day })\end{array}$ \\
\hline $\mathrm{Al}$ & 1.34 & 402 \\
$\mathrm{Ca}$ & 0.78 & 234 \\
$\mathrm{Cl}$ & 1.04 & 312 \\
$\mathrm{Fe}$ & 1.87 & 561 \\
$\mathrm{~K}$ & 0.17 & 51 \\
$\mathrm{Mg}$ & 0.05 & 15 \\
$\mathrm{Na}$ & 0.06 & 18 \\
$\mathrm{Si}$ & 2.64 & 792 \\
$\mathrm{Ti}$ & 0.07 & 21 \\
\hline
\end{tabular}

$a_{\text {Values derived from rẹf. 30, }}$ pp. 11-12.

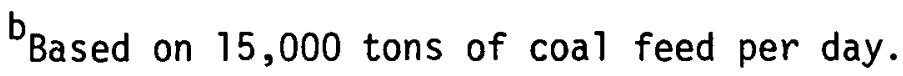


made on the fate of the trace elements. A trace-element analysis for the ORNL Bench-Scale Hydrocarbonizer has been published. ${ }^{40,41}$ The results of this work are summarized in Table 5.3. The reactor temperature and holding time are similar to that of the coalcon design; ' however, because the product recovery system is quite different, the oil-aqueous splits could be very different in the Coalcon process.

The Synthane process is a high-BTU gasification process, but the reactor products are similar to those of hydrocarbonization. Again, due to a higher reactor temperature and differences in product recovery schemes, the trace-element data from the Synthane PDU are not directly applicable to hydrocarbonization; however, they do help reveal overall trends in the fate of the trace elements. Workers at the Pittsburgh Energy Research Center (PERC) ${ }^{42}$ have made an effort to analyze all major streams in the Synthane PDU and have reported trace-element balances, which are summarized in Tables 5.4 and 5.5. The mass balances shown in Table 5.5 are off by as much as a factor of 5 , because the analytical technique used is considered to be accurate to approximately a factor of 3 . Condensate from the Synthane process has been analyzed by a more accurate method..$^{27,29}$ These results are shown in Table 5.6.

Workers at the Institute of Gas Technology (IGT) have studied the fate of trace elements in the Hygas gasification process ${ }^{43}$ which has two stages of hydrogasification and one stage of electrothermal gasification at increasing temperatures of 650,950 , and $1000^{\circ} \mathrm{C}$. The trace-element analyses and proximate analyses are shown in 
Table 5.3. Fate of trace elements ${ }^{a}$ in ORNL hydrocarbonization unit and effluent standards

(weight ppm)

\begin{tabular}{|c|c|c|c|c|c|}
\hline Element & Coal & Char & $0 i 1$ & $\begin{array}{l}\text { Sour } \\
\text { water }\end{array}$ & $\begin{array}{l}\text { Effluent } \\
\text { standards }\end{array}$ \\
\hline $\mathrm{Ba}$ & 510.0 & 1570.0 & 10.0 & 0.4 & 2.0 \\
\hline $\mathrm{Cd}$ & 0.2 & 0.9 & 0.1 & $<1.0$ & 0.15 \\
\hline $\mathrm{Cr}$ & 7.0 & 18.0 & 3.0 & 0.1 & $0.1-1.0$ \\
\hline $\mathrm{Cu}$ & 9.0 & 17.0 & 2.5 & 0.06 & 1.0 \\
\hline $\mathrm{Fe}$ & 1700.0 & 3800.0 & 95.0 & 1.0 & 1.0 \\
\hline In & 0.2 & 0.7 & 0.1 & $<1.0$ & \\
\hline Mo & 0.2 & 1.1 & 0.1 & 0.01 & \\
\hline $\mathrm{Ni}$ & 5.0 & 10.0 & 7.0 & 1.0 & 1.0 \\
\hline $\mathrm{Pb}$ & 3.0 & 7.0 & 0.2 & 0.003 & 0.1 \\
\hline$S r$ & 320.0 & 490.0 & 4.0 & 0.1 & \\
\hline $\mathrm{Tl}$ & 0.3 & 0.4 & 0.1 & 0.02 & \\
\hline $\mathrm{Zn}$ & 6.0 & 14.0 & 1.5 & 0.06 & 1.0 \\
\hline
\end{tabular}

${ }^{a}$ values derived from ref. 40, p. 5.

${ }^{b}$ See columns "Anticipated regulations," Table 6.1 in this report. 
Table 5.4. Trace-element analysis for the Synthane Process ${ }^{a}$ (ppm)

\begin{tabular}{|c|c|c|c|c|}
\hline El ement & $\begin{array}{l}\text { Illinois No. } 6 \\
\text { feed coal }\end{array}$ & Char & $\mathrm{H}_{2} \mathrm{O}$ & Effluent standard ${ }^{b}$ \\
\hline Al & 2,200 & 1,900 & 0.007 & \\
\hline As & 1.2 & 4.2 & $<0.001$ & 0.25 \\
\hline B & 86 & 280 & 20 & \\
\hline $\mathrm{Ba}$ & 150 & 110 & 0.08 & 2.0 \\
\hline $\mathrm{Ca}$ & $>10,000$ & $>10,000$ & 2.7 & \\
\hline $\mathrm{Cl}$ & 130 & 20 & 220 & 0.2 \\
\hline $\mathrm{Cr}$ & 120 & 190 & 0.018 & $0.1-1.0$ \\
\hline $\mathrm{Cu}$ & 35 & 34 & 0.003 & 1.0 \\
\hline$F$ & 400 & 240 & 36 & 15 \\
\hline $\mathrm{Fe}$ & $>5,000$ & $>10,000$ & 0.12 & 1.0 \\
\hline $\mathrm{Hg}$ & 0.11 & 0.04 & 0.029 & \\
\hline $\mathrm{k}$ & 5,000 & 4,400 & 0.36 & \\
\hline $\mathrm{Mg}$ & 1,700 & 3,200 & 0.63 & \\
\hline Mn & 200 & 300 & 0.075 & 1.0 \\
\hline $\mathrm{Na}$ & 1,900 & $>8,200$ & 6.3 & \\
\hline $\mathrm{Ni}$ & 21 & 25 & 0.007 & 1.0 \\
\hline$P$ & 110 & 1,100 & 0.034 & \\
\hline $\mathrm{s}$ & $>5,000$ & 2,200 & 0.97 & \\
\hline $\mathrm{Se}$ & 1.3 & 4.4 & 0.11 & 1.0 \\
\hline Si & $>10,000$ & $>10,000$ & 4.7 & \\
\hline Sr & 6.9 & 65 & 0.07 & \\
\hline $\mathrm{Zn}$ & 8.3 & 89 & 0.078 & 1.0 \\
\hline
\end{tabular}

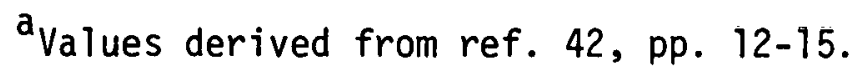

bee columns under "Anticipated regulations," Table 6.1 in this report. 
Table 5.5. Fate of trace elements in the Synthane gasification process ${ }^{a}$

\begin{tabular}{lrrrrr}
\hline Element & $\begin{array}{c}\text { Condensate } \\
(\%)\end{array}$ & $\begin{array}{c}\text { Tar } \\
(\%)\end{array}$ & $\begin{array}{c}\text { Char } \\
(\%)\end{array}$ & $\begin{array}{c}\text { Filter } \\
\text { fines } \\
(\%)\end{array}$ & $\begin{array}{c}\text { Recovery } \\
(\%)\end{array}$ \\
\hline As & 0.1 & 3.0 & 60.2 & 4.9 & 69.0 \\
B & 120.6 & 0.6 & 58.6 & 0.6 & 180.3 \\
Be & 0.0 & 0.2 & 280.8 & 5.0 & 286.1 \\
Cd & 0.0 & 0.0 & 509.7 & 11.5 & 521.0 \\
Cl & 258.3 & 0.02 & 4.7 & 0.09 & 263.2 \\
Cr & 0.0 & 0.1 & 69.3 & 0.4 & 69.8 \\
F & 14.5 & 0.0 & 27.0 & 3.0 & 44.5 \\
$\mathrm{Hg}$ & 47.4 & 10.6 & 15.7 & 0.9 & 75.4 \\
$\mathrm{Mn}$ & 0.0 & 0.0 & 22.9 & 0.2 & 23.2 \\
$\mathrm{Ni}$ & 0.1 & 0.4 & 78.8 & 2.2 & 81.4 \\
$\mathrm{P}$ & 0.1 & 0.3 & 152.7 & 0.1 & 153.1 \\
$\mathrm{~Pb}$ & 0.0 & 1.2 & 326.3 & 6.2 & 333.7 \\
$\mathrm{Se}$ & 40.8 & 0.6 & 206.5 & 19.5 & 267.3 \\
$\mathrm{U}$ & 0.0 & 0.1 & 49.4 & 2.0 & 51.4 \\
$\mathrm{~V}$ & 0.0 & 0.1 & 42.3 & 1.7 & 44.1 \\
$\mathrm{Zn}$ & 0.3 & 0.1 & 42.4 & 0.7 & 43.5 \\
\hline
\end{tabular}

${ }^{a}$ Values derived from ref. 42 , p. 20. 
Table 5.6. Comparison of effluent standards and two trace-element analyses for the Synthane aqueous condensatea

\begin{tabular}{|c|c|c|c|c|}
\hline \multirow[b]{2}{*}{ Element } & \multicolumn{2}{|c|}{$\begin{array}{c}\text { Concentration } \\
\text { (mg/liter) }\end{array}$} & \multirow[b]{2}{*}{ Average } & \multirow{2}{*}{$\begin{array}{l}\text { Effluent } \\
\text { standards }\end{array}$} \\
\hline & No. 1 & No. 2 & & \\
\hline $\mathrm{Ca}$ & 4.4 & 3.6 & 4.0 & \\
\hline $\mathrm{Fe}$ & 2.6 & 2.9 & 3.0 & 1.0 \\
\hline $\mathrm{Mg}$ & 1.5 & 1.8 & 2.0 & \\
\hline A1 & 0.8 & 0.7 & 0.8 & \\
\hline Se & 0.401 & 0.323 & 0.360 & 1.0 \\
\hline$k$ & 0.117 & 0.204 & 0.160 & \\
\hline $\mathrm{Ba}$ & 0.109 & 0.155 & 0.130 & 2.0 \\
\hline$P$ & 0.082 & 0.092 & 0.090 & \\
\hline $\mathrm{Zn}$ & 0.044 & 0.083 & 0.060 & 1.0 \\
\hline Mn & 0.036 & 0.038 & 0.040 & 1.0 \\
\hline $\mathrm{Ge}$ & 0.032 & 0.061 & 0.040 & \\
\hline As & 0.044 & 0.028 & 0.030 & 0.25 \\
\hline $\mathrm{Ni}$ & 0.023 & 0.034 & 0.030 & 1.0 \\
\hline Sr & 0.033 & 0.024 & 0.030 & \\
\hline Sn & 0.025 & 0.026 & 0.020 & \\
\hline $\mathrm{Cu}$ & 0.016 & 0.020 & 0.020 & 1.0 \\
\hline $\mathrm{Cb}$ & 0.007 & 0.005 & 0.006 & \\
\hline $\mathrm{Cr}$ & 0.004 & 0.002 & 0.003 & $0.1-1.0$ \\
\hline V & 0.004 & 0.002 & 0.003 & \\
\hline Co & 0.001 & 0.002 & $0.00^{\prime 2}$ & \\
\hline
\end{tabular}

${ }^{a}$ Values derived from ref. 27, p. 4.

bee columns under "Anticipated regulations," Table 6.1 in this report. 
Table 5.7. Although the hydrogasification char is similar to hydrocarbonization char, direct use of these numbers to predict the content of hydrocarbonization trace elements would be misleading.

The Coalcon plant has been designed in such a way that the greatest portion of the trace elements will end up in the ash sluicing water either in solution or in the solid phase of the slurry. However, small amounts of some of the more volatile elements (e.g., mercury, chlorine, selenium, arsenic, lead, cadmium) may get into other streams. It is not now possible to predict the amounts of some of the elements known to form compounds with the organics (e.g., vanadium, germanium) that will be in the oil products. Some trace elements tend to concentrate on the surface of small particles present in gas effluent streams, ${ }^{44}$ but we cannot predict whether these will be significant problems in a hydrocarbonization plant.

\subsection{Polynuclear Aromatic Hydrocarbons}

Coal conversion, particularly hydrocarbonization and carbonization processes, produce large amounts of polynuclear aromatic hydrocarbons (PNAs) in the heavy tar fractions. This has been a cause for concern, since many of the larger ringed PNA compounds produced are suspected of being highly carcinogenic and mutagenic. These PNAs are only slightly soluble in water, but are considered hazardous even at low concentrations. Furthermore, PNAs are not removed by the common wastewater treatment processes and may not be amenable to microbial destruction. ${ }^{45}$ Therefore, it will be important to segregate and recycle aqueous streams containing PNAs to prevent their discharge to the environment. 
Table 5.7. Trace element and proximate analysis of Hycas products ${ }^{a}$

\begin{tabular}{|c|c|c|c|c|c|}
\hline Product & $\begin{array}{c}\text { Ráw } \\
\text { Pittsturgh } \\
\text { No. } 8 \text { coal }\end{array}$ & $\begin{array}{l}\text { Pretreated } \\
\text { coal }\end{array}$ & $\begin{array}{c}\text { Second stage } \\
\text { char }\end{array}$ & $\begin{array}{l}\text { Electrothermal } \\
\text { char }\end{array}$ & $\begin{array}{l}\text { Total } \\
\text { loss } \\
(\%)\end{array}$ \\
\hline \multicolumn{6}{|c|}{ Based on coal feed (ppm) } \\
\hline $\mathrm{Hg}$ & 0.27 & 0.19 & 0.06 & 0.01 & 96 \\
\hline $\mathrm{Se}$ & 1.7 & 1.0 & 0.65 & 0.44 & 74 \\
\hline As & $9 . \overline{5}$ & 7.5 & 5.1 & 3.4 & 65 \\
\hline Te & 0.11 & 0.07 & 0.05 & 0.04 & 64 \\
\hline $\mathrm{Pb}$ & 5.9 & 4.4 & 3.3 & 2.2 & 63 \\
\hline $\mathrm{Cd}$ & 0.73 & 0.59 & 0.41 & 0.30 & 62 \\
\hline Sb & 0.15 & 0.13 & 0.12 & 0.10 & 33 \\
\hline V & 33.0 & 36.0 & 30.0 & 23.0 & 30 \\
\hline $\mathrm{Ni}$ & $: 2.6$ & 11.0 & 10.0 & 9.1 & 24 \\
\hline $\mathrm{Be}$ & 0.92 & 1.0 & 0.94 & 0.75 & 18 \\
\hline $\mathrm{Cr}$ & 15.0 & 17.0 & 16.0 & 15.0 & 0 \\
\hline \multicolumn{6}{|c|}{ Proximate analysis (as receivez, wt $\%$ ) } \\
\hline Moisture & 1.4 & 3.7 & 0.8 & 0.2 & \\
\hline Volatile matter & 38.6 & $\therefore 2.4$ & 2.2 & 2.1 & \\
\hline Ash & 17.6 & 12.3 & 22.1 & 45.0 & \\
\hline Fixed carbon & 43.4 & 61.6 & 74.9 & 52.7 & \\
\hline
\end{tabular}

${ }^{a}$ Values derived from reg. 43, pp. 13,21 . 
Very little reliable data are available concerning the PNA concentration in coal conversion process streams; however, all streams that contact the organic products (including washdown and rainwater runoff) are likely to contain PNAs and should be treated accordingly.

\section{GOVERNMENTAL REGULATIONS}

The Federal Water Pollution Control Act of 1972 requires the EPA to establish guidelines for technology-based effluent limitations which must be achieved by point sources of discharge into the navigable waters of the United States. At the present time, federal regulations for the control of pollutants in wastewater streams are issued as industryspecific rules. Since no coal conversion industry exists as yet, the only guidelines as to what future federal regulations might be can be obtained by comparing existing similar industries. These industries include iron and steel (coke making), petroleum refining, steam electric power generating, and coal mining. All of these industries utilize various operational units that would be common to a coal conversion industry.

\subsection{Existing Regulations}

One requirement of the Water Pollution Control Act requires the achievement (by not later than July 1,1977 ) of effluent limitations for point sources that are based on the application of the best practicable control technology currently available (BPCTCA). This level is generally based on the average of the best existing performance. ${ }^{46}$

A second section also requires the achievement (by not later than July 1,1983 ) of effluent limitations for point sources that are based 
on the application of the best available technology economically achievable (BATEA), ${ }^{46}$ which will result in further reasonable progress toward the national goal of eliminating the discharge of all pollutants. Best available technology is not based on an average of the best performance within an industry category, but will be determined by identifying the very best control and treatment technology employed by a specific point source.

Effluent limitations for new sources are specificd by the degree of effluent reduction achievable through the application of the best available demonstrated control technology (BADCT). New facilities will not be constructed until new source performance standards (NSPS) have been published. Existing federal regulations for four industries are tabulated in Table 6.1 , both in units as written in the regulation and in units that can be compared to coal liquefaction. Effluent limitations for new sources are the guidelines that are listed except for coal mining where the BPCTCA limits are the only gutdelines available.

Generally, the BATEA guidelines are the most stringent, either being equivalent to the new source standards or, in the case of petroleum refining, only about $25 \%$ of the new source guidelilies for most pollutants. In some cases, substitution of the BATEA guidelines would noticeably lower the anticipated limits, especially for biological oxygen demand (BOD); chemical oxygen demand (COD), oil and grease, phenols, $\mathrm{NH}_{3}$, and hexavalent chromium.

The range for any one pollutant varies widely from industry to industry. Part of this may be due to the conversion of units, but a significant factor is that existing federal regulations tend to allow 
Table 6.1. Wastewater effluent regulations

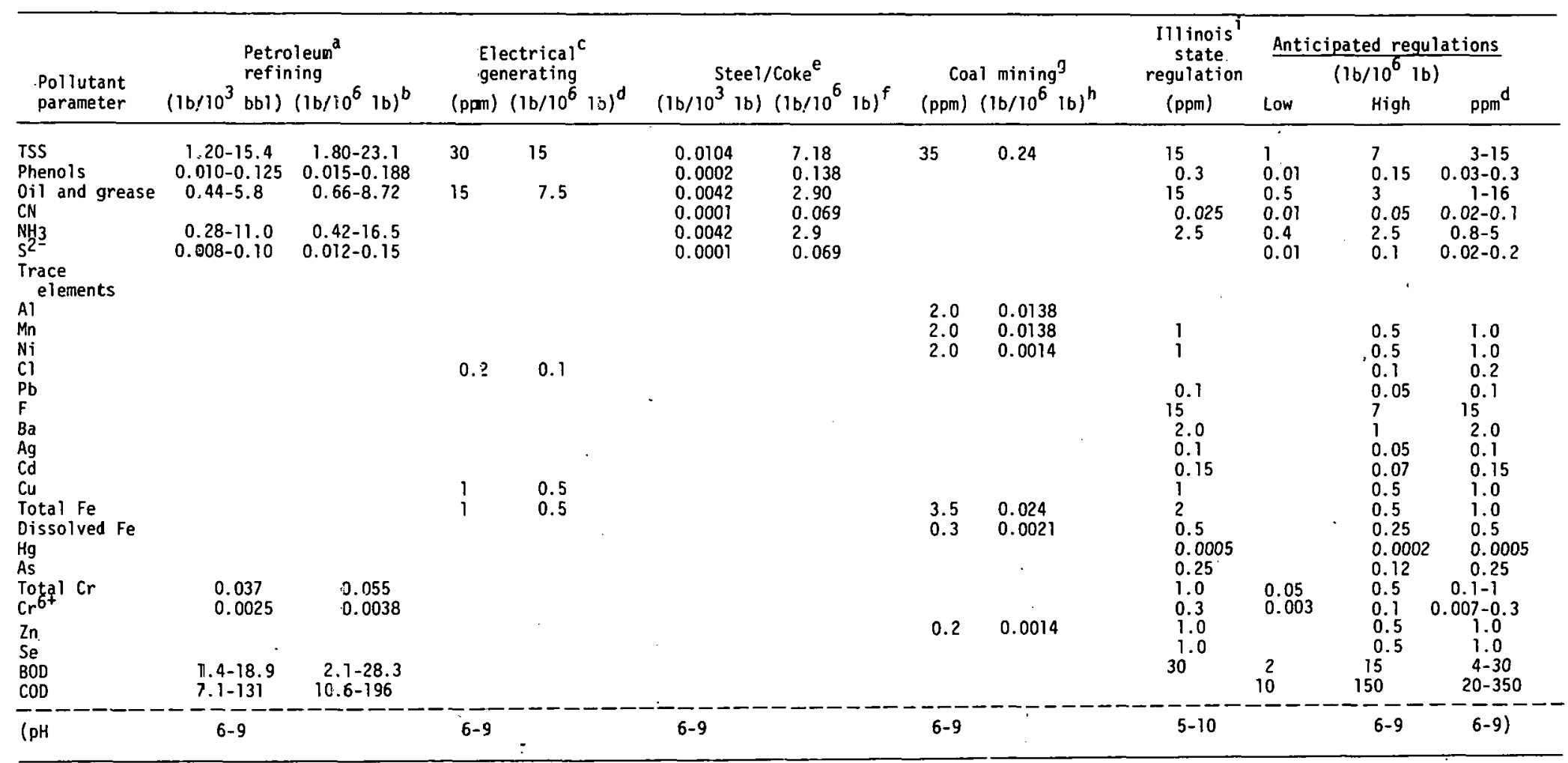

avalues derived from ref. 47.

based on 3 bbl of oil per ton of coal.

$c_{\text {Values derived from ref. } 43 .}$

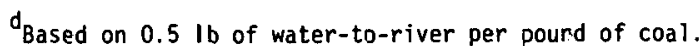

evalues derived from ref. 46

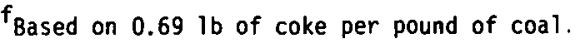

9 Values derived from ref. 49.

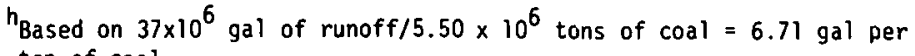
ton of coal.

${ }^{i}$ Values derived from ref. 50. 
an industry that emits more of a certain waste product to have a higher limit for that waste product than an industry that does not produce as much.

Another complicating factor is that private industry expects regulations to be written in terms of pounds of effluent per pound of feedstock (or product) rather than in what would seem to be a simple concentration $(\mathrm{ppm})$. This does, however, allow for very concentrated effluent streams from plants that tend to discharge a minimum of wastewater. The regulations listed in Table 6.1 have therefore been converted to a pounds-per-pound of coal feedstock basis.

\subsubsection{Iron and steel industry}

In the iron and steel industry, coke making is often an integral part of the total process and specific regulations have been written for this operation. 47 In the Coalcon flowsheet, 1 the hydrocarbonization, ammonia recovery, ammonia stripping, and acid-gas removal steps are all similar to those in coke production. Regulations are listed for $\mathrm{pH}$, total suspended solids (TSS), phenols, oil and grease, cyanide, and ammonia on a pound of effluent per pound of product coke basis. These were converted to a pound of coal basis by assuming $0.69 \mathrm{lb}$ of coke per pound of coal.

\subsubsection{Petroleum refining}

Steps in the coal conversion process such as methandion, sulfur recovery, acid-gas removal, and ammonia recovery are similar to operations in many refineries. Effluent limits are given for $\mathrm{pH}, \mathrm{BOD}$, COD, TSS, oil and grease, phenols, ammonia, sulfide, and chromium. ${ }^{48}$ Regulations have been established on the basis of pounds of effluent 
per barrel of feedstock. A variety of conversion factors could have been used, but it has been assumed that 1 ton of coal is roughly equivalent to $3 \mathrm{bbl}$ of petroleum.

\subsubsection{Steam electric power generation}

The Coalcon flowsheet has an integral steam generation plant associated with it, and effluent standards for coal-fired electric power generating stations should be applicable. ${ }^{49}$ In this case, regulations for TSS, oil and grease, chlorine, copper, and iron are given on a concentration basis. The conversion factor used was $0.5 \mathrm{lb}$ of final wastewater per pound of coal.

\section{1 .4 Coal mining}

Any overlap between the operations conducted in coal mining and those of a hydrocarbonization facility would be relatively minor and essentially limited to coal handling and coal pile runoff. Effluent limits are for a variety of trace elements and are given as milligrams per liter. ${ }^{50}$ In this case, a conversion factor of $0.00167 \mathrm{lb}$ of water per pound of coal throughput was used. This number only holds for the coal pile runoff and is obviously only a small part of the total plant wastewater. A 90-day supply of coal was assumed to be present in the coal pile.

The only other Federal regulations in effect are those for drinking water which were set by the U.S. Public Health Service (USPHS). Although these standards were dcsigned for use in regulating the quality of water supplied to common carriers engaged in interstate commerce, they have become the standard for all public water supplies in the country through adoption hy the various state health departments. 
Some of these standards are mandatory requirements, other are recommended 1imits. In addition, the American Water Works Association adopted a series of potable water quality goals which, in some cases, are more exacting than the USPHS standards. Also, additional limits for a variety of substances have been suggested for inclusion in the next version of the Drinking Water Standards. All these are included in Table 6.2. It is important to note that these are standards for receiving bodics of water and not effluent streams, (i.e., no credlt is given for any d11ution errét).

\section{1 .5 State regulations}

Most states have written regulations to enforce limitations on the quality of wastewater that can be discharged to various bodies of water within their boundaries. However, most of these regulations are based on the minimal quality level permitted in a particular body of water and not on a plant-effluent basis. These limits usually vary depending on the type of use (e.g., recreation, drinking water supply) for the body of water. Any discharge that would tend to raise the water pollutant levels above the predetermined level would be disallowed.

Illinois, which has attracted a number of demonstration coal conversion units, is one of the few states that has set actual discharge 1imits for a variety of pollutants. 55 These limits are given in parts per million and can be converted by using the conversion factor of $0.51 \mathrm{~b}$ of final wastewater per lb of coal feedstock.

\subsection{Anticipated Regulations}

The proposed anticipated regulations are based on the various existing regulations for other related industries. In most cases, a 
Table 6.2. Drinking water standards (ppm)

\begin{tabular}{|c|c|c|c|c|}
\hline Constituent & Mandatory ${ }^{\mathrm{a}}$ & Recommended & Goars ${ }^{c}$ & Sugges ted ${ }^{d}$ \\
\hline Al & & & 0.05 & \\
\hline $\mathrm{Sb}$ & & & & 0.05 \\
\hline As & 0.05 & 0.01 & & \\
\hline $\mathrm{Ba}$ & 1.0 & & & \\
\hline B & & & & 1.0 \\
\hline $\mathrm{Cd}$ & 0.01 & & & \\
\hline $\mathrm{Cl}^{-}$ & & 250 & & \\
\hline $\mathrm{Cr}^{6+}$ & 0.05 & & & - \\
\hline $\mathrm{Cu}$ & & 1.0 & 0.2 & \\
\hline $\mathrm{CN}^{2-}$ & 0.20 & & & \\
\hline $\mathrm{F}^{-}$ & $1.4-2.4$ & & & \\
\hline $\mathrm{Fe}$ & & 0.3 & 0.05 & \\
\hline $\mathrm{Pb}$ & 0.05 & & & \\
\hline Mn & & 0.05 & 0.01 & \\
\hline $\mathrm{Hg}$ & 0.002 & & & \\
\hline $\mathrm{Se}$ & 0.01 & & & \\
\hline $\mathrm{Ag}$ & 0.05 & & & \\
\hline $\mathrm{Zn}$ & & & 1.0 & \\
\hline Phenols & & 0.001 & & \\
\hline
\end{tabular}

${ }^{a}$ Data derived from ref. 51.

bata derived from ref. 52.

${ }^{\mathrm{C}}$ Data derived from ref. 53.

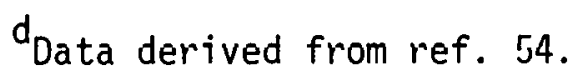


range of values has been indicated because of the large variation between existing industries in the amount of pollutant that can be released. Usually the high end of the range has been determined by the highest existing regulation for an industry that would not emit an excessive amount of that particular pollutant. Lower limits have been determined by the smallest limits for a related industry. In no cases were limits based on an estimation of any future technology.

\section{CLEANUP TECHNOLOGIES}

The complexity of the various aqueous streams from a coal conversion plant such as the Coalcon hydrocarbonization plant has made the "best" processes for waste cleanup somewhat doubtful. At the same time, the sure enactment of stricter effluent standards has put pressure on new coal conversion processes to dispose adequately of their wastes. A variety of treatment processes are suitable for use in a coal conversion plant, as shown below. This list is not complete, but is probably representative.

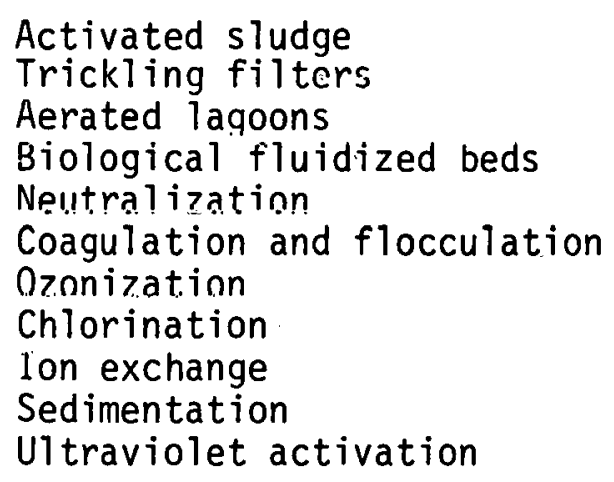

Activated sludge

Trickling filters

Aerated lagoons

Biological fluidized beds

Neutralization

Coagulation and flocculation

Ozonization

Chlorination

lon exchange

Sedimentation

Ultraviolet activation

\author{
Flotation \\ 0 il separation \\ Stripping \\ Solvent extraction \\ Adsorption \\ Combustion \\ Wet. nxidation \\ Filtration and ultrafiltration \\ Reverse osmosis \\ Electrolys is
}

Many of these processes will require some form of pretreatment. Some will also be used to produce clean process and potable water for the plant. A few of the most useful processes for hydrocarbonization waste- 
water cleaning are discussed below in relation to their adaptability to the specific pollutants found in these wastewaters. Only those technologies that show promise of immediate application to coal conversion wastewaters have been investigated. Some (e.g., neutralization or oil separation) will definitely be applied to some wastewater streams, are commercially available, and will need little or no modification. Others (e.g., electrolysis and uv activation) are of such a nature that little application is seen for the immediate future.

\subsection{Biological Degradation}

The most widely used method to control aqueous organic pollutants are those that can be grouped under the broad category of biological degradation. In its various forms, biological degradation can include everything from dumping raw wastewater into the nearest waterway and letting the natural purifying properties of the environment take charge, to highly sophisticated reactors that utilize specially selected bacteria that would be unable to survive under natural conditions. The biological means have included a wide variety of bacteria of the aerobic and anaerobic types, algae, and even higher-order plants such as water hyacinths. Reactors have varied from the simple natural or man-made ponds to complicated, tapered-fluidized-bed reactors. Cost and reliability are such that when organics need to be degraded, biological means are usually the method of choice, whether the industry is iron and steel or municipal sewage disposal. 
Normally, the following items are considered in the design of a biological oxidation process:

Need for pretreatment. In some situations, a simple filtering or settling step can vastly improve the performance of a biological oxidation unit. Special pretreatment other than neutralization inay occasionally be needed for the particular bacteria to perform under optimal conditions. This may include sparging to remove excessive dissolved gases such as $\mathrm{NH}_{3}, \mathrm{H}_{2} \mathrm{~S}$, or $\mathrm{CO}$. In some cases, this step may be so difficult it will preclude the use of biological treatment such as with some metal pickling wastes.

Need for flow equalization. This step may be necessary to equalize any changes in volume or composition of flows. This can be a major problem where a variety of different process plants can be operating at different times. In other cases, such as in municipal sewage treatment, only flow equalization may he a problem.

Need for stream dilution. Most compounds, even those being used by the bacteria as a carbun source, can be detrimental at excessive levels. In these cases, a simple recycle may prove necessary even though it can add considerable pumping costs to the unit and increases the size and capital cost.

Need för stream nutrification. Although many bacterial strains ean survive and even grow under stressful envirnnmental conditions, the addition of nutrients such as trace elements, phosphorus, and nitrogen are often needed for optimal cell growth and pollutant degradation. Type of blological oxidation unit to be considered. A variety of biological oxidation units in various stages of development are available. 
These include trickle-bed filters, complete mix tanks, aerated lagoons, simple holding ponds, and fluidized-bed systems. Each type has its advantages such as efficiency, cost, and operating difficulty.

0xidation or retention time needed. Each of the above types of biological unit will require a characteristic contact time depending on the process stream to be treated. Times may range from several minutes to several days.

If biological oxidation is to be considered for the treatment of hydrocarbonization wastewater, the needs listed above should be examined in connection with the specific problems arising from hydrocarbonization.

Various pretreatment steps will definitely need to be included if any ammonia recovery or removal steps have not reduced the $\mathrm{NH}_{3}$ concentration below the level of 1500 to $2000 \mathrm{ppm}$ that most bacteria can tolerate. 56 Some untreated wastewater from the hydrocarbonization reactor may be as high as $30,000 \mathrm{ppm}$. Although this level will be diluted before discharge, the quantities of $\mathrm{NH}_{3}$ may still be too high. Suspended matter will be present but should not consist of particles large enough to cause concern.

Flow equalization should not be a major problem. In most conversion processes, the individual units that produce wastewater will either all be operating or the entire system will be shut down. Variations in the flow rates may exist, but compositions should remain relatively constant, especially for commercial units. The problem will need to be carefully examined in pilot plant and demonstration units, because fluctuations in operating conditions will produce large deviations in the composition of wastewaters. 
In complete mix tanks, aerated lagoons, and simple holding ponds the outflow concentration is equal to the steady-state reactor concentration. Stream dilution is already occuring and no additional dilution will be needed. However, for trickle-bed filters and fluidized beds, stream dilution will have to be included in the system design. Expected phenol levels to $6000 \mathrm{ppm}$ greatly exceed the 200 to $300-\mathrm{ppm}$ level. tolerated for optimum phenol removal. 57,58 Recycling of effluent would probably be the optimum way of achieving the necessary amount of dilution.

Stream nutrification is likely to be only a minor problem. The large variety of chemicals found in hydrocarbonization wastewater will probably contain many of the trace elements needed (Tables 4.8-4.10, 4.12). A rough rule of thumb is that the ratio between $\mathrm{BOD}_{5}$ (where " 5 " indicates days), nitrogen, and phosporus should be 100:5:1. The large amount of $\mathrm{NH}_{3}$ present should provide the necessary nitrogen. Phosporous may need to be added to achieve the above ratio. However some experimental data from the ORNL hydrocarbonization experiment would indicate that much of the necessary phosporous may also be present. In this case, a hydrocarbonization quench water containing 8150-ppm carbon also contained 20-ppm phosphate.

In choosing a biological oxidation unit to treat hydrocarbonization wastewater streams, various párameters such as installed costs, operating costs, and efficiency will have to be considered. The following expression was developed as the result of a survey made by the Dow Chemical Company in 1973. It can be considered applicable to coal- 
conversion wastewater treatment for estimating the total annual operating costs:

$$
Q(43.1)+\left(\frac{Q}{812}\right)^{0.6}(88,800),
$$

where $Q$ is the organic loading in $1 b / d a y .{ }^{59}$ since the reference hydrocarbonization plant produces $1.0 \times 10^{6}$ gal of water per day at $5000-p p m$ phenol, the above expression results in $\$ 0.17$ per pound of phenol, or approximately $\$ 7000$ per year per $10^{6}$ gal of water. If an inflation-correction factor of $1.39(1973-1977)$ is used, it will result in $\$ 0.24$ per pound of phenol and $\$ 9700$ per year per $10^{6} \mathrm{gal}$ of water.

In 1969, the South Tahoe Public Utility District, South Lake Tahoe, California, built an advanced wastewater treatment facility. ${ }^{34}$ This plant treated organic constituents for $\$ 0.07 / 1 \mathrm{~b}$ or $\$ 2700 \mathrm{year}^{-1}$ $10^{-6}$ gal. Using an inflation-correction factor of 2.15 (1967-1977) results in $\$ 0.14 / 1 \mathrm{~b}$ and $\$ 6000$ year $^{-1} 10^{-6}$ gal. These numbers compare quite reasonably with those above considering the different types of facilities involved.

The oxidation or retention time needed is a strong function of the type of reactor chosen, but there is usually a range of times for any one type of unit. Factors to be considered include the degree of removal required, and hydraulic loading. Many of the components present in hydrocarbonization wastewater may be quite refractory to biological oxidation, especially during the short oxidation times required in trickle-bed filters and fluidized beds. On the other hand, the several-day residence times that would be needed in aerated lagoons 
will possibly allow the polymerization of phenols into PNA with the possibility of having higher PNA levels in the effluent than the feed. Apparently, the potential application for biological oxidation of hydrocarbonization wastewater is very good. Numerous experiments have shown that phenol levels, the major contaminant in hydrocarbonization wastewater, can be reduced by up to $99.9 \%$ to levels as 10 as $20 \mathrm{ppb} .^{57,60}$ Trace metals and PNA would be more refractory, although previous work has shown that up to 50 to $90 \%$ of heavy metals such as cadmium, lead, copper, nickel, mercury, iron, and zinc can be removed by biological oxidation. ${ }^{61-71}$ The metals would be tied up in organic sludge that is produced as a byproduct. PNAs seem to be relatively untreated and, in fact, may be increased for those units that have long residence times. ${ }^{72}$

Several other areas are of concern in the application of biological oxidation, including the need for elevated temperatures, especially during the cooler months of the year. Temperatures of $25^{\circ}$ to $35^{\circ} \mathrm{C}$ seem to be optimum for móst. biological systems and, in some cases, lemperatures of $45^{\circ}$ to $60^{\circ} \mathrm{C}$ are desirable, with a temperature of at least $10^{\circ} \mathrm{C}$ being necessary. ${ }^{73-76}$

Another case of concern is by-product disposal. The carbon content of the wastewater streallis will be converted to some extent by changes in operating conditions, but some biomass in the form of sludge will be produced. This sludge will contain live and dead bacterid with the possible presence of a high concentration of heavy metals. Some form of land disposal or incineration will need to be provided. In the past, this sludge has often been applied to agricultural lands, but the high concentration of metal will probably preclude this disposal technique. ${ }^{77-80}$ 


\subsection{Chlorination and Ozonation}

Several chemical oxidation processes are presently being used to treat both wastewater and drinking water. These processes include chlorine treatment and ozonation. Gaseous chlorine, chlorine dioxide, and sodium hypochlorite have been used as final polishing steps in wastewater treatment and as a method of supplying residual bactericidal potential. However, the advisability of using chlorine in treating wastewater heavily laden with phenolics is highly questionable. Many authorities have discussed the formation of chloroderivatives of phenolics, and several have commented on the toxicity of these compounds. ${ }^{81-84}$

When PNAs are chlorine treated, a significant reduction in concentration can be expected. Sforzolini ${ }^{85}$ indicated that chlorine as chlorine water showed an effective reduction in a variety of PNAs of $100 \%$ for 3,4-benzopyrene to $15 \%$ for 3,4-benzofluoroanthene. Both Sforzolini $i^{85}$ and Muller and Reichert ${ }^{86}$ have shown that chloroderivatives are formed in the process, and, although Muller and Reichert have shown that some chloroderivations of carcinogenic PNAs are not carcinogenic, it would seem wise to avoid chlorinating known toxic and carcinogenic compounds.

Ozone, a very strong oxidizing agent, is used to oxidize hydrocarbons to simple organic compounds or to completely oxidize them to inert compounds such as water and carbon dioxide. These simpler compounds usually have fewer undesirable effects such as color, malodor, toxicity, or carcinogenic effects. When a wastewater containing hydrocarbons is subjected to ozone treatment, a situation similar to that shown in Fig. 7.1 is usually observed. ${ }^{87}$ 


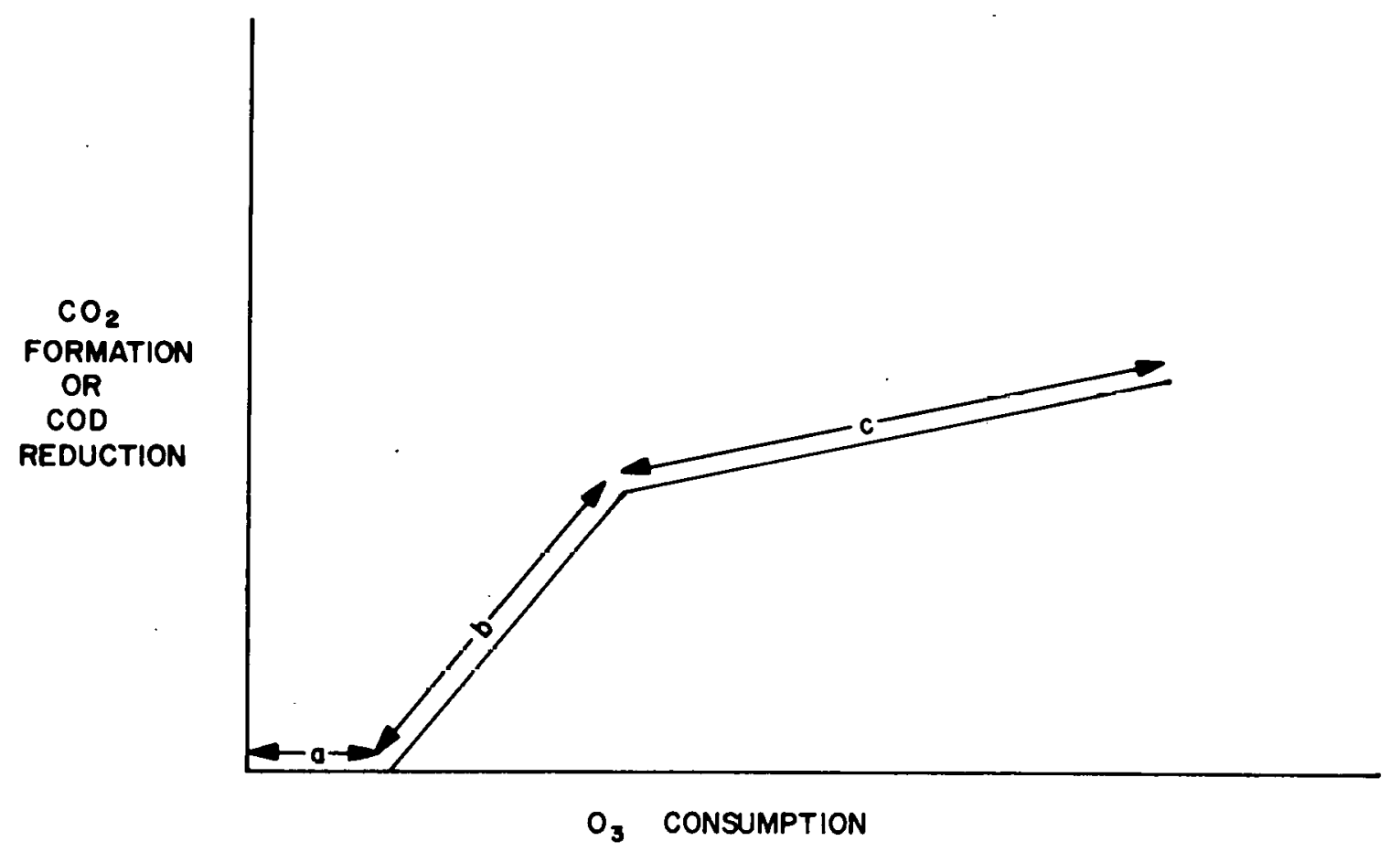

Fig. 7.1. Typical ozonation curve. 
An initial period, a, is usually explained by the conversion of complex hydrocarbons to simple oxidation products. The slope $b$ represents the oxidation of hydrocarbons to the final carbon dioxide and water products. The last segment, $c$, often has a slope near zero and can be interpreted as the simple recombination of ozone back to oxygen with very little carbon being oxidized during this period. The process is usually only 30 to $60 \%$ efficient; that is, only 30 to $60 \%$ as much carbon dioxide is produced as the stoichiometry of the ozone reactions would indicate.

Apparently, ozone treatment is one of the few means of achieving reasonable reductions in PNA content without producing other questionable compounds. Reichert ${ }^{88}$ found that when 3,4-benzopyrene in water at concentrations of 1 to $100 \mathrm{mg} / \mathrm{liter}$ was placed in contact with ozone at concentrations of 0.5 to $1.5 \mathrm{mg} / 1$ iter for $30 \mathrm{~min}$, it decreased in content by $-99 \%$. Sforzolini et al. ${ }^{85}$ showed effective reduction in a variety of PNAs ranging from $100 \%$ for 3,4-benzopyrene and $11,12-$ benzofluoroanthene to $70 \%$ for 3,4-benzofluoroanthene. Unlike the similar tests with chlorine, there was no evidence of new compounds being formed when ozone was used.

A wide variety of ozone generation equipment is available for commercial use, and progress is being made on upgrading the effectiveness of these generators. ${ }^{89}$ However, present indications are that the complcte oxidation of hydrncarbons cannot be achieved economically with ozone. $^{87,90}$ If either a very small amount of hydrocarbon needs to be treated, or if only a small amount of degradation is needed, as would be the case when a complex toxic compound can be degraded to a slightly 
less complex nontoxic compound, ozonization may have an advantage. In 1973, Kroop 91 reported costs for the ozone degradation of phenol wastes of approximately $\$ 0.75 / 1 \mathrm{~b}$, or about $\$ 1.00 / 1 \mathrm{~b}$ at today's prices. Three other references for phenol removal by ozone $87,92,93$ give ozone requirements of 2 to $3 \mathrm{lb}$ of ozone per pound of phenol. If the ozone is $\$ 0.30 / 1 b$ (including capital costs for ozone generation), the equivalent is $\$ 0.60$ to $\$ 0.90$ per pound of phenol.

\subsection{Coagulation and Flocculaliun}

Impurities in coal conversion wastewater vary in size from dissolved substances that are a few angstroms to suspended materials that are a few hundred microns. Normally sedimentation is used to remove a large fraction of these particles; but, because many of these substances are too small for gravitational settling to be effective, the aggregation of these particles into larger masses that settle more readily is essential for successful sedimentation. This process of agglomeration is often termed coagulation.

Much confusion is associated with the terms coagulation and flocculation because they are often used interchangeably. Coagulation is the chemical reaction resulting in the production of complex hydrous oxtdes. It is very fast and only requires enough time to disperse the chemical coagulation agents throughout the liquid. Flocculation is usually applied to the agglomeration of coagulated solids to produce solids that can be settled or filtered. It is during this process that much of the colloidal material not involved in the chemical reaction of the coagulant can be agglomerated. This agglomeration may be improved 
by stirring the water to increase the number of collisions between coagulated particles, in which case, it is necessary to keep the precipatate in suspension long enough for the agglomeration to occur. Camp ${ }^{94}$ and Hudson ${ }^{95}$ have discussed the various details of flocculator design.

Coagulation can frequently occur under natural conditions. In biological treatment processes, the microorganisms aggregate themselves to a point at which they will settle out. Under some conditions, the agglomerated sludge can even absorb colloidal organic substances in wastewater in a shorter time than is required to remove these materials by biological oxidation.

Several investigators have indicated that as much as $80 \%$ of the $\operatorname{COD}$ of some wastewater streams may be contained in particles that are colloidal or larger in size, and up to $50 \%$ of the total organic carbon in the effluent of biological treatment plants may be colloidal. ${ }^{96}$ In addition to exerting an oxygen demand, these colloidal materials can severly impair the efficiency of ion exchange, adsorption, and membrane processes used to remove soluble substances as a final polishing step. 97

Traditionally, lime, alum, iron salts, or, more recently, polyelectrolytes have been used for this coagulation process. Lime reacts with the bicarbonate in the water to form insoluble calcium carbonate as in the following reaction:

$$
\mathrm{Ca}(\mathrm{OH})_{2}+\mathrm{HCO}_{3}^{-} \rightarrow \mathrm{CaCO}_{3}++\mathrm{H}_{2} \mathrm{O}+\mathrm{OH}^{-} \text {. }
$$


As the $\mathrm{pH}$ increases due to the resulting alkalinity, other compounds will begin to precipitate. One of the first will be magnesium hydroxide:

$$
\mathrm{Mg}^{+}+2 \mathrm{OH}^{-} \rightarrow \mathrm{Mg}(\mathrm{OH})_{2}{ }^{+} .
$$

Magnesium hydroxide normally precipates when the $\mathrm{pH}$ is in the range 9 to 11 ; it is a gelatinous material that can remove many colloidal particles as it settles. Magnesium is often present in significant quantities and is also added as an impurity to the lime.

Calcium carbonate can be recalcined to recover the calcium oxide content. However, in cases where large amounts of organies and/or heavy metals may have been removed from the wastewater, the recalcining may allow for the creation of a new air pollution source or for the reintroduction of heavy metals back into the waste stream.

When alum, $\mathrm{Al}_{2}\left(\mathrm{SO}_{4}\right)_{3}$, is added to alkal ine wastewater, the following reaction occurs:

$$
\mathrm{Al}_{2}\left(\mathrm{SO}_{4}\right)_{3}+6 \mathrm{OH}^{-} \rightarrow 2 \mathrm{Al}(\mathrm{OH})_{3} \downarrow+3 \mathrm{SO}_{1}^{2-} .
$$

In this case the addition of alum tends to lower the $\mathrm{pH}$.

In some situations, the addition of both lime and alum can be used first to raise the $\mathrm{pH}$ and then to lower it, although the dense chemical sludges thus produced may be difficult to thicken and dewater.

Iron coagulation relies on the reaction between the ferric ion and the dissolved phosphate ion. This reaction can be useful for municipal residential wastewaters that contain significant quantities of phosporous, but may not be helpful for coal conversion wastewaters.

Polyelectrolytes can be used as primary coagulants, but normaliy their application is limited to use as coagulation or flocculation aids. 
Under certain conditions, lime or alum, alone or in combination, may produce a fine, slow-settling precipitate. In these cases, a variety of commercially available polymers, such as those produced by Calgon, Nalco, and Dow, produce a rapidly settling precipitate.

Of secondary importance in most sewage treatment facilities, but possibly of immense importance in coal conversion wastewater cleanup, is the ability of coagulants to remove heavy metals. Calculations in the literature have shown that when $\mathrm{Pb}^{2+}, \mathrm{Cu}^{2+}$, and $\mathrm{Cr}^{3+}$ are precipitated, they leave a concentration of about $1 \mathrm{ppm}$ at a pH of $\sim 7$. $\mathrm{A} \mathrm{pH}$ of $\sim 9$ to 9.5 is needed to reduce the concentration of $\mathrm{Zn}^{2+}, \mathrm{Ni}^{2+}$, and $\mathrm{Cd}^{2+}$ to below 1 ppm. 98

Lime coagulation, by nature of its raising the $\mathrm{pH}$ to a point at which many of the trace metals form insoluble hydroxides, results in a reduction in the concentration of these metals. Culp and Culp 99 summarized the available data and listed removals of 80 to. $99.9 \%$ for a wide variety of metals. Where the dissolved metal is in an organic form, removal efficiencies were much lower, often less than $10 \%$. In addition, filtration to remove residual particulate matter can often provide additional removal of heavy metals. For example, Culp and Culp reported additional literature values of 2.6 to $95 \%$ for seven metals with the use of filtration.

Alum coagulation is usually not considered as effective as lime in metal removal, but one study showed metal removal of 18 to $99 \%$ for five metals (lead, copper, magnesium, $\mathrm{Cr}^{6+}, \mathrm{Cr}^{3+}$, cadmium, and zinc). Nickel was not removed. 98 
Costs for coagulation and flocculation vary widely depending on the wastewater to be treated. Assuming a representative dose of $3.3 \mathrm{lb}$ per $1000 \mathrm{gal}$ of effluent ( $400 \mathrm{mg} / \mathrm{liter}$ ), and a price of $\$ 50$ per ton of lime (including capital equipment costs), a cost of $\$ 80$ per million gallons of effluent is obtained. ${ }^{34,100}$ Assuming that coagulation would remove $50 \%$ of the organic matter present, this would be less than $\$ 0.01 / 1 \mathrm{~b}$ removed.

\subsection{Solvent Extraction}

Recently, several researchers ${ }^{101,102}$ have worked on a varicty of solvents for phenol removal in both typical solvent extraction systems and dual solvent processes (polar solvent-volatile solvent). In all cases, it is necessary to identify and quantify the major pollutants present in order to choose the appropriate solvents. Regardless of the high-distribution coefficients reported for many of these systems, the Lurgi Phenosolvan process seems to be the only one that has been commericalized. Lurgi developed this process in the 1940s, and about 30 commercial Phenosolvan plants have since been installed in the coke production and petroleum industries. This process uses isopropyl ether as the solvent in multistage mixer settlers. The phenol-rich solvent is usually distilled to recover solvent for reuse and is then stripped to remove and recover any residual solvent. The dephenolized aqueous phase is also gas-stripped to recover solvent. Although the solvent for this type of contactor is chosen because of its high-distribution coefficient for phenol, other types of organics will also be stripped out of the aqueous phase. 
A recent article on the Phenosolvan process discussed its applicability to coal gasification wastewater. ${ }^{103}$ The Phenosolvan process should remove $99.5 \%$ of the monohydric phenols (e.g., phenol, cresol, xylenol), $60 \%$ of the polyhydric phenols (catechol, resorcinol), and $15 \%$ of other organics. This may leave an aqueous stream that might contain as much as $20 \mathrm{ppm}$ of monohydric phenols, $500 \mathrm{ppm}$ of polyhydric phenols, and $1800 \mathrm{ppm}$ of other organics. The crude phenol produced may have a composition of $80 \%$ monohydric phenols, $15 \%$ polyhydric phenols, and $5 \%$ other organics.

Although a significant amount of phenol and other organics can be removed by the Phenosolvan process, a large quantity of polyhydric phenols and other organics remain in the effluent stream. The process would seem to be advantageous only if a moderate reduction in phenolic content is needed to allow an additional waste treatment plant to operate, or where a salable crude phenol can be produced economically. The first case will still be expensive, and there is some question whether the crude phenol produced is of a quality to be used as a chemical feedstock.

A recent review ${ }^{101}$ indicated that if the value of the recovered phenol is greater than $\$ 3 / 1000$ gal; then recovery is promising. At $5000 \mathrm{ppm}$ of phenol, this is equal to $\$ 0.07$ per pound of phenol compared with bulk prices of $\$ 0.26$ per pound of phenol. 100 Product upgrading may, however, prove to be quite expensive, and the remaining contaminants in the aqueous stream will require treatment. 


\subsection{Sorption}

Adsorption of dissolved organics on activated carbon is a welldeveloped water treatment process. Activated carbon adsorption has been used both in treatment of industrial wastes and for polishing of potable water. In addition, activated carbon adsorption processing has the potential to recover the removed "pollutants" in an economically valuable form. Sorbents other than activated carbon (e.g., polar macroreticular resins and hydrogásification or hydrocartonization char) are potentially useful for removal and/or recovery of dissolved pollutants, whereas activated carbon systems have exhibited several problems. For example, they are known to be costly, and they involve some extensive solids handling problems (i.e., in most cases the carbon must either be transferred between the sorption vessel and the regeneration vessel or it must be disposed of).

Activated carbon treatment of wastewater is a well-developed and growing treatment process, especialiy at the pilot and demonstration levels. 104-109 Although these references (and others too numerous to catalog) provide an excellent base of experience, there has been less experience with wastewater streams similar to those normally found in a hydrocarbunicalion plant. Baker ct al. ${ }^{110}$ have reported a successfut activated carbon treatment plant that operates with an industrial waste high in cresylics (which are likely to be tound in hydrocarbuniza= tion wastewater). In addition, the carbon was regenerated in such a way that the valuable cresols were returned to the upstream process, allowing this "waste treatment process" to actually show a profit. This plant was of reasonable size ( $240 \mathrm{gal} / \mathrm{min})$ and operated on a fairly 
concentrated waste $(0.3$ to $0.5 \%$ cresylics). Workers at Reichhold Chemicals, Inc. (RCI), 111 have operated a larger carbon treatment plant (350 gal/min) with a more dilute waste stream (phenol, $420 \mathrm{ppm}$; COD, $3773 \mathrm{mg} /$ liter). They have shown good success and operability using an activated carbon system, which was found to be superior to an activated sludge system that was also tested. The workers at RCI also found that regeneration of the carbon with acid or caustic solutions was, at best, partially effective for this wastewater.

Workers at Hercules Inc. 112 have successfully operated a commercialscale $\left(2.6 \times 10^{6} \mathrm{gal} /\right.$ day $)$ activated carbon secondary treatment unit. This unit was operated on naval stores wastewater containing oily waste (COD, $750 \mathrm{mg} / 1$ iter; TOC, $203 \mathrm{mg} / 1$ iter, phenol, $4.7 \mathrm{mg} / 1$ iter). The plant appeared to remove a large quantity of organic species and showed about $70 \%$ removal for some trace metals (nickel, zinc, cadmium, copper, chromium). The carbon was regenerated in a multiple-hearth furnace with a 3 to $5 \%$ loss of carbon per cycle. The regenerated carbon was shown to be slightly more active than virgin carbon, and no information was given on the fate of the trace metals in the regeneration process. A German study ${ }^{56,113}$ of activated carbon treatment of coking wastes includes results of some pilot plant studies. The coking wastewater is probably similar to hydrocarbonization wastewater (50 to $3200 \mathrm{mg} / 1 \mathrm{iter}$ phenol, plus ammonia, cyanides, etc.).

There will be a large incentive in a hydrocarbonization plant (or any coal conversion plant producing a solid carbonaceous residue) to replace activated carbon in the treatment step with char. Researchers at. PERC 114 have reported good adsorption of Synthane wastes on Synthane 
char. The use of char as an adsorbent would remove the need for a carbon regeneration step in the waste treatment flowsheet. The spent char can be used as fuel for a gasifier or boiler thereby recovering the dissolved pollutants as fuel. The use of hydrocarbonization char as an adsorbent in a wastewater treatment step is an area that warrants further study.

In addition to activated carbon and hydrocarhonization char, there is a class of neutral macroreticular resins which may be useful in wastewater treatment in coal conversion plants. These resins act similarly to activated carbon in sorption characteristics but are composed of a synthetic styrene polymer. Research has shown that these resins have a high affinity for phenolics and PNA, but their high cost may make neutral resins unattractive for wastewater treatment.

Al though much work has been done on the sorption characteristics of phenolics on activated carbon, very little information is available. on sorption of PNA. However, some pertinent information on the effects of trace elements is available. A radiochemical study of adsorption of inorganic ions carried out at the Japan Atomic Energy Research Institute tested activated carbon adsorption for 44 elements as a function of pH. Some of the important trace elements in wastewater treatment (arsenic, selenium, lead, mercury) were omitted. In addition, this study was carried out with laboratory stock solutions that did not contain other contaminants which may effect sorption.

Additional information on activated carbon sorption of inorganic species is found in water and sewage treatment literature. 115-117 These studies have concentrated on four elements (silver, cadmium, 
chromium, selenium) and show varying degrees of removal ( $95 \%$ for silver, cadmium, and chromium, and $40 \%$ for selenium). There is also some speculation ${ }^{116}$ that the sorption of the trace inorganics may be enhanced by the presence of organic species.

No discussion of sorption can be complete without consideration of regeneration. The carbon or other sorbent must be regenerated (or reactivated) when saturated to allow for another cycle of adsorption; otherwise, the sorbent is discarded and fresh sorbent is used. Loven ${ }^{118}$ lists five classes of regeneration processes which can be placed in two groups, chemical and thermal.

Thermal regeneration refers to heating the carbon to vaporize the adsorbed organics. For adsorbed volatile organics, steam stripping is sufficient to regenerate the carbon; however, when heavier species are present, as is the case in most wastewater treatment processes, more severe heating is necessary. In this case, the adsorbed materials are pyrolyzed, carbonized, and gasified at temperatures to $2000^{\circ} \mathrm{F}$. This processing can be carried out in rotary kilns, multiple-hearth furnaces, 119 transport reactors, ${ }^{120,121}$ or similar equipment. Hutchins ${ }^{122-124}$ has published papers on the costs associated with thermal regeneration. Chemical regeneration refers to washing the carbon with a solvent or reactive solution to remove the adsorbed material. This technique is especially applicable when the dissolved "waste" can be economically utilized if recovered. However, chemical treatment may not be severe enough to fully regenerate carbons from hydrocarbonization waste processing. As mentioned earlier, washing with acid and caustic solutions did not adequately regenerate carbon used in waste treatment 
of a stream similar to that found in hydrocarbonization. 112 However, regeneration of adsorbed phenolics using sodium hydroxide solution has been demonstrated to be profitable. 110,125 Calculations in one of these reports $^{125}$ show that sodium hydroxide regeneration can compete with thermal regeneration, even without recovery of a valuable by-product. If an activated carbon treatment was to be used on hydrocarbonization by-product water, chemical regeneration would probably be inadeyuale to regenerate the carbon. It may be possible, however, to partially regenerate the carbon with sodium hydroxide, thereby recovering a relatively uncontaminated phenolic by-product and further reactivating the carbon by other means.

Activated carbon is considered moderately expensive, with cost estimates of $\$ 0.40$ to $\$ 6.00$ per pound of phenol (most estimates are in the $\$ 0.50$ to $\$ 1.00 / 1 \mathrm{~b}$ range) for carbon adsorption--thermal regeneration, and either reactive or solvent recovery methods become economical at high concentrations of phenol. ${ }^{126}$ This wide range of values makes cost comparisons difficult.

\subsection{Membrane Processes}

Several separation processes involving membranes have been studied, but only reverse osmosis, ultrafiltration, and electrodialysis. will be considered here. In reverse osmosis and ultrafiltration, the separation is achieved by passing the water through a membrane with the concentrated solute (or particulates) left behind; conversely, in electrodialysis, the solutes pass through the membrane (via an electric potential driving force) leaving the purified solvent behind. These membrane processes, although considered expensive, may 
be useful in upgrading wastewater for inplant reuse. Although no tests of membrane purification have been performed on streams such as those derived from coal conversion, general reviews based on related experience are available. ${ }^{127}$

In electrodialysis, only ionic species in the feed permeate the membrane. For this reason, electrodialysis is usually used in demineralizing and deashing solutions such as the desalination of water. Hence electrodialysis could be used as a sidestream treatment to remove electrolytes from a recirculating stream. Although electrodialys is is routinely used for demineralizing water solutions with a high-organic content, ${ }^{128}$ the effects of phenolics and PNA are not known. No data have been reported on the electrodialys is of streams similar to those found in coal conversion plants, and electrodialysis is apparently not applicable to coal conversion wastes, with the possible exception of cooling tower wastewaters.

Reverse osmosis ${ }^{129,130}$ and ultrafiltration ${ }^{131}$ have been studied in depth as a means for treatment of liquid wastes. Both reverse osmosis and ultrafiltration processes have been tested on oily wastewater. The study of reverse osmosis ${ }^{132}$ showed good rejections of 011 , COD, and total dissolved solids, but a poor (50\%) rejection of phenol. The ultrafiltration study ${ }^{133}$ considered only oil rejection, which was quite high. The ultrafiltration process produced an oil stream that was suitable for reuse or as fuel. However, phenol rejections for membrane processes are not promising. One work shows poor (8 to 45\%) removals for reverse osmosis, ${ }^{132}$ and little rejection of phenol can be expected using ultrafiltration. Another study of organically contaminated 
wastewater $^{134}$ showed no rejection of phenols but recorded varying rejections (0 to $90 \%$ ) for 37 other organic solutes. The aromatic alcohols tested in this study showed very poor rejections, indicating that reverse osmosis would have little or no effect on many of the oxygenated hydrocarbons found in the wastewater from a coal conversion plant.

Since reverse osmosis has long been used for desalting brackish water, it may find its best use in a coal conversion plant. Chian and Fang $^{135}$ have made a study of the feasibility of using reverse osmosis as treatment for reuse of cooling tower blowdown. The use of reverse osmosis for treating blowdowns and ash pond water, which can be quite similar in composition to brackish water, looks promising and should be considered in more detail. Reverse osmosis treating of these streams will be an expensive means of producing feed water, but may be necessary in arid regions.

It is difficult to estimate the economics involved in membrane processes. Communications with various vendors of reverse osmosis equipment have optimistically discussed numbers in the range $\$ 2000$ to $\$ 6000 / 10^{6}$ gal. At $280 \%$ phenol removal, this would be approximately $\$ 0.05$ to $\$ 0.15$ per pound of phenol. However, this still produces a concentrated mixed phenols-aqueous stream that needs further concentration and processing, and a dilute aqueous stream that contains unacceptable levels of organics, which would necessitate additional cleanup. 


\section{SUMMARY}

A hydrocarbonization process ${ }^{1}$ has been studied to assess environmental control technology for coal conversion wastewaters. The first phase of this program was the identification of the sources, magnitudes, and character of the wastewater streams. Fifteen major wastewater streams were identified. Table 8.1 summarizes the magnitudes and characteristics of the major wastewater streams. A brief description of these streams as well as other major plant streams can be found in Table 3.2. Of the 15 major wastewater streams, only 2 present serious environmental problems not routinely encountered in industry today. These are the hydrocarbonization condensate (stream 19) and the ash sluicing waste from the gasifier (stream 42). The hydrocarbonization product water, as seen in Table 8.1 , is high in phenoliçs, ammonia, cyanide, thiocyanate, and other sulfur compounds. This stream will present a significant wastewater treatment problem unless the stream can be recycled internally, which would be the case if it can be used as a feed to the hydrogen production unit. The gasifier-ash sluicing water will probably be similar to ash sluicing water from coal-fired power generating plants. However, the large quantity of toxic trace elements may be more easily dissolved from ash produced at the lowertemperature and reducing conditions encountered in gasification.

In addition to the flowsheet study, the coal conversion literature was surveyed to obtain information on wastewater streams from processes similar to hydrocarbonization. Processes for which pertinent wastewater information is available include COED, Synthane, U.S. Steel Clean Coke, and other similar processes. These sources have bcen used to 
Table 8.1. Identity 0 ₹ nydrocarbonization waste streams

\begin{tabular}{|c|c|c|c|c|c|c|c|c|c|c|}
\hline $\begin{array}{c}\text { Haste } \\
\text { stream } \\
\text { Nc. } \\
\end{array}$ & $\begin{array}{c}\text { Flow rate } \\
(1 \mathrm{~b} / \mathrm{hr})\end{array}$ & pH & $\begin{array}{c}\text { Total suspended } \\
\text { solids } \\
\text { (ppm) }\end{array}$ & $\begin{array}{c}\text { Phenoli=s } \\
(\mathrm{ppm})\end{array}$ & $\begin{array}{c}\text { joluble } \\
\text { hyd -ocarjons } \\
\text { (ppm) }\end{array}$ & $\begin{array}{c}\text { inmonia } \\
\text { (ppm) }\end{array}$ & $\begin{array}{c}\text { Hydrogen } \\
\text { sulfide } \\
(\mathrm{ppm})\end{array}$ & $\begin{array}{l}\text { Trace }{ }^{2} \\
\text { elemerts } \\
\text { (ppm) }\end{array}$ & $\begin{array}{c}\text { Other } \\
\text { solubles } \\
\text { (ppm) }\end{array}$ & $\begin{array}{l}\text { oil and } \\
\text { grease } \\
\text { (ppm) }\end{array}$ \\
\hline 3 & $530^{3}$ & $2-5$ & $100-4000$ & -0 & -0 & $0.3-2.0$ & -0 & c & $\begin{array}{l}\mathrm{SO}_{4}^{2^{-}}-20,000 \\
\text { Metal sulfides }\end{array}$ & -0 \\
\hline 10 & 125,000 & $7-10$ & -0 & 100 & $<50$ & $<50$ & $<10$ & A & $\begin{array}{l}C N<20 \\
S C N<50\end{array}$ & Trace \\
\hline 19 & $105,05 \dot{0}$ & $8-10$ & -0 & $10^{3}-10^{4}$ & $500-1000$ & $5000-30,000$ & $200-1000$ & B & $\begin{array}{ll}\text { CN } & 10-200 \\
\text { SCN } & 100-2000\end{array}$ & $<10,000$ \\
\hline 23 & 12,331 & $5-0$ & -0 & Trace & Trace & Trace & 0 & $A^{\circ}$ & -0 & Trace \\
\hline 25 & $175,00]$ & $5-9$ & $\cdot 0$ & $200-6000$ & $100-600$ & $<100$ & $<25$ & B & $\begin{array}{ll}\text { CN } & 6-120 \\
\text { SCN } & 60-1200\end{array}$ & $<6,000$ \\
\hline $2 ?$ & 52,000 & $5-9$ & 0 & $<10$ & $<5$ & Trace & $<1000$ & A & -0 & Trace \\
\hline 3? & 38,000 & -7 & -0 & -0 & -0 & -0 & -0 & A & -0 & -0 \\
\hline 42 & 86,587 & $8-13$ & $6000-200,000$ & -0 & -0 & $<200$ & -0 & c & $\begin{array}{l}\mathrm{CN}, \mathrm{SCN} \\
<1 \text { ppm }\end{array}$ & -0 \\
\hline 43 & 1,715 & $9-i 2$ & $-a$ & $0-1.2$ & $0-1$ & $<1-50$ & $<0.1$ & A & Salts $10-500$ & -0 \\
\hline 53 & $342,5 x$ & $8-; 3$ & $6000-200,000$ & -0 & -10 & 0 & -0 & c & -0 & -0 \\
\hline 57 & $30,00 x$ & $9-12$ & -0 & $0-12$ & $0-1$ & $<1-50$ & $<0.1$ & A & Salts $10-500$ & -0 \\
\hline 53 & 160,000 & $5-9$ & $50-4000$ & Trace & Trace & Trace & -0 & B & $\begin{array}{l}\text { Salts traces } \\
\mathrm{CN} \text { and SCN }\end{array}$ & $<50$ \\
\hline 53 & 358,000 & $7-10$ & $<230$ & 0.1 & Trace & $1-80$ & 0.1 & $A-B$ & Salts $\sim 2400$ & Trace \\
\hline 65 & $70,0<0$ & $9-12$ & $15,030-150,000$ & 0 & $\operatorname{COD} \stackrel{n}{=}$ & 0 & 0 & $B-C$ & $\begin{array}{c}\text { Salts } 2090- \\
\quad 12,000\end{array}$ & 0 \\
\hline 67 & 265,0010 & -7 & Trace & 0 & -0 & 0 & 0 & A. & $\begin{array}{l}\text { Salts } \\
\quad 4000-18,000\end{array}$ & 0 \\
\hline
\end{tabular}

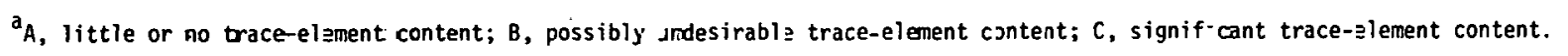

Based on 90-day reserve storage pi ${ }^{-}$.' 
estimate the concentration data in Table 8.1. Tables 8.2 through 8.10 summarize the data and identify the source of the data for each of the water quality criteria shown in Table 8.1. Scaling of these data could be misleading unless flows, temperatures, pressures, methods, and other pertinent information are considered. Each table presents the data for one water quality index. For each stream in these tables, the data source (i.e., pilot plant, laboratory studies, etc.) and the reference are listed with a description of the data (space permitting), average, or range of data. In addition, a reliability-applicability index is included. This column represents a judgment (possibly somewhat subjective) as to the pertinence of the data from that particular source. This judgment considers such factors as the relation of the data source to hydrocarbonization (e.g., certain data from another pyrolysis process are more applicable than similar data from a low-BTU gasification process) and the scale of the investigation producing the data (i.e., for our purposes, pilot plant data are considered more reliable than laboratory-scale data).

Federal effluent limitation guidelines applicable to coal conversion have also been estimated by reviewing the effluent 11 mits of related industries. These anticipated regulations are tabulated on two bases in the last two columns of Table 8.11: mass of pollutant per mass of coal, and concentration of pollutant in the effluent stream. Federal regulations use the former basis for effluent limitation guidelines, whereas some states and most of the scientific community use the latter basis. 
Table 3.2. Data sources for $\mathrm{pH}$

\begin{tabular}{|c|c|c|c|c|}
\hline $\begin{array}{l}\text { Stream } \\
\text { iNo. }\end{array}$ & Comments & $\begin{array}{l}\text { Data source } \\
\text { (ref.) }\end{array}$ & $\mathrm{pH}$ & $\begin{array}{l}\text { Reliability- } \\
\text { applicabilitya }\end{array}$ \\
\hline 3 & Analyses of coal storage runoff & 22 & $\begin{array}{l}2-8 \text { overall } \\
2-5 \text { high-sulfur coal }\end{array}$ & A \\
\hline 10 & $\begin{array}{l}\text { No data available tut assumed to be similar to } \\
\text { stream } 19\end{array}$ & & $7-10$ & B \\
\hline \multirow[t]{2}{*}{19,25} & Analyses of COED pilot plant first- and second-stage condensate & 25 & $3.6-9$ & A \\
\hline & Analysis of Synthane PDU condensate & 27 & $8.6-9.3$ & A \\
\hline 37 & Water of methanation, free of contaminants & 30 & $\sim 7$ & A \\
\hline \multirow[t]{2}{*}{42,53} & $\begin{array}{l}\text { Batch equilibrium experiments with ash from coal fired } \\
\text { power plants }\end{array}$ & 21 . & 8.2-12.5 & B \\
\hline & Analysis of ash quezching water from Koppers-Totzek gasifier & 32 & 8.8 & A \\
\hline \multirow[t]{2}{*}{43,57} & Analyses of boiler Jlowdown from coal sinef power plants & 22 & $9-11$ & A \\
\hline & Analyses of boiler blowciown from petroieun refineries & 4 & $10-12$ & A \\
\hline 58 & iNo data availasle, assumed to be approximately neutral & & $5-9$ & $C-B$ \\
\hline 59 & $\begin{array}{l}\text { Analyses of cooling water from petroleum refineries; this } \\
\text { could be hignly variable due to the rilmber and magnitude } \\
\text { of process leaks. }\end{array}$ & 4 & $6-8$ & B \\
\hline \multirow[t]{2}{*}{66} & Typical value =or l:me coagulation slucge & 34,35 & $\subseteq-12$ & A \\
\hline & Typical value =or aium coagulation sludge & 22 & $5-9$ & A \\
\hline 67 & Typical value jor icn exchange waste & & 27 & A \\
\hline
\end{tabular}

${ }_{A}^{a}$, very reliable-appiicable; $B$, ir.termediate; $C$, marginally reliable-applicable. 
Table 8.3. Data sources for suspended solids

\begin{tabular}{|c|c|c|c|c|}
\hline $\begin{array}{l}\text { Stream } \\
\text { No. }\end{array}$ & zomments & $\begin{array}{l}\text { Data source } \\
\quad(r e f .)\end{array}$ & $\begin{array}{c}\text { TSS } \\
\text { (mg/liter) }\end{array}$ & $\begin{array}{l}\text { Reliability- } \\
\text { applicability }\end{array}$ \\
\hline 3 & Analyses of coal storage runoff & 22 & $100-4,000$ & A \\
\hline 10 & No data available & & & \\
\hline 19 & Assumed to be low due to product recovery configuration & & 20 & A \\
\hline 23 & $\begin{array}{l}\text { Assumed to be near zero since this stream is condensate } \\
\text { from a stream that has been washed and cooled }\end{array}$ & & no & A \\
\hline 25,27 & $\begin{array}{l}\text { Assumed to be near zero since this stream was formed } \\
\text { from clean streams }\end{array}$ & & 20 & A \\
\hline 37 & Water of methanation is free of suspended solids & 30 & & . \\
\hline 42,53 & Analyses of ash handling water in coal fired power plants & 22 & $6,000-200,000$ & A \\
\hline 43,57 & Boiler blowdown very low in suspended solids & 22 & 20 & A \\
\hline 58 & No data available, assumed similar to stream 3 & & $50-4,000$ & $C-B$ \\
\hline 59 & $\begin{array}{l}\text { Upper limit for suspended solids in recirculating } \\
\text { cooling water }\end{array}$ & 22 & $<400$ & $A-B$ \\
\hline 66 & $\begin{array}{l}\text { Typical values for clarifier sludge from lime or alum } \\
\text { flocculation }\end{array}$ & 22 & $15,000-150,000$ & $A-B$ \\
\hline 67 & No data available, assumed $\sim_{0}$ & & 20 & $A-B$ \\
\hline
\end{tabular}

${ }^{a} A$, very reliable-applicable; $B$, intermediate; $C$, marginally reliable-applicable. 
Table 8.4. [rata sources for phenolics

\begin{tabular}{|c|c|c|c|c|}
\hline $\begin{array}{l}\text { Stream } \\
\text { No. }\end{array}$ & Comments & $\begin{array}{l}\text { source } \\
\text { (ref.) }\end{array}$ & $\begin{array}{l}\text { Concentration } \\
\text { (my/liter) }\end{array}$ & $\begin{array}{l}\text { Reliability- } \\
\text { applicability }\end{array}$ \\
\hline 3 & Analyses if runofī from coal storage & 22 & 0 & A \\
\hline 10 & $\begin{array}{l}\text { No data evailable, assumed to be similar to stream } \\
19 \text {, but more dibute }\end{array}$ & & $<700$ & C \\
\hline \multirow[t]{4}{*}{19} & Analyses of U.S. Iteel, Clean Coke Process PDí, condensate & 23 & 6000 & A \\
\hline & Analyses of FMC CDED pilot plant firsi-stage condensate & 26 & 6000 & A \\
\hline & Analyses of PERC-5ynthane PDU condensate & 27 & $2000-6000$ & B-A \\
\hline & Analyses of PERC-Synthane POU condensate & 26 & $\sim 5000$ & B-A \\
\hline 23 & $\begin{array}{l}\text { No data available, assumed to be zern because of nature } \\
\text { of the stream }\end{array}$ & & 20 & $B-A$ \\
\hline 25 & $\begin{array}{l}\text { No data available, bL: only small amount of phenolics } \\
\text { is los: ir the ammenia stripper }\end{array}$ & & $200-6000$ & $B-A$ \\
\hline 27 & No data available & & & \\
\hline 37 & Water of methanation free of phenolics & 30 & थ0 & A \\
\hline 42,53 & Ash slurries found to have no phenolics & 22,32 & $\sim 0$ & A \\
\hline 43,57 & Analyses of boiler biowdown from petroleum refineries & 4 & $0-1.2$ & A \\
\hline 58 & No data $\equiv v a-l a b l e$, as sumed to be present in small quantitie & & Trace & C \\
\hline 59 & Analyses of cooling water from petroleum refineries & 4 & $<0.1$ & B \\
\hline 66,67 & $\begin{array}{l}\text { Water treatnent wastes will reflect the phenolic content } \\
\text { of river water: should be near zera. }\end{array}$ & & 20 & A \\
\hline
\end{tabular}

${ }_{A}^{a}$, very reliable-applicabie; B, intermediate; $C$, marg:nally reliable-applicable 
Table 8.5. Data sources for soluble hydrocarbons

\begin{tabular}{|c|c|c|c|c|}
\hline $\begin{array}{l}\text { Stream } \\
\text { No. }\end{array}$ & Commenis & $\begin{array}{l}\text { Data source } \\
\text { (ref.) }\end{array}$ & $\begin{array}{l}\text { Concentration } \\
\quad(\mathrm{mg} / \mathrm{liter})\end{array}$ & $\begin{array}{l}\text { Reliability- } \\
\text { applicability }\end{array}$ \\
\hline 3 & Analyses of runoff from coal storage & & $\operatorname{COD}=100$ & B \\
\hline 10 & iNo data available & & & . \\
\hline \multirow[t]{3}{*}{19} & $\begin{array}{l}\text { Analyses of FMC COED pilot plant, first-stage } \\
\text { condensate }\end{array}$ & 26 & $\sim 800$ & B \\
\hline & Analyses of PERC Synthane PDU condensate & 26 & ఒ 800 & B \\
\hline & Analyses of PERC Synthane PDU condensate & 27 & $\operatorname{COD}=2000-5000$ & B \\
\hline 23 & $\begin{array}{l}\text { No data available, assumed near zero, due to nature } \\
\text { of the stream }\end{array}$ & & no & A \\
\hline 25 & $\begin{array}{l}\text { No data available but only small amount of soluble } \\
\text { hydrocarbons will be lost in the ammonia stripper }\end{array}$ & & $100-600$ & $A$ \\
\hline 27 & No Jata available & & & \\
\hline 37 & Water of methanation free of hydrocarbons & 30 & 20 & A \\
\hline 42,53 & $\begin{array}{l}\text { Ash slurries found to be very low in soluble. } \\
\text { hydrocarbons }\end{array}$ & 22,32 & $\sim 0$ & A \\
\hline 43: 57 & Analyses of boiler blowdown from petroleum refineries & 4 & $C O D=100-1000$ & B \\
\hline 58 & No data available, should be present in small quantities & & Trace & C \\
\hline 59 & Analyses of cooling water from petroleum refineries & 4 & $\mathrm{COD}=100-200$ & B \\
\hline 66 & Analyses of water treatment wastes & 22 & $C O D=500-10,000$ & B \\
\hline 67 & Demineralizer wastes free of hydrocarbon contamination & 22 & no & B \\
\hline
\end{tabular}

${ }_{A}$, very reliable-applicable; $B$, intermediate; $C$, marginally reliable-applicable. 
Table 8.6. [lata sources and comments for ammonia

\begin{tabular}{|c|c|c|c|c|}
\hline $\begin{array}{l}\text { Stream } \\
\text { No. }\end{array}$ & Comments & $\begin{array}{l}\text { Data source } \\
\quad(\text { ref.) }\end{array}$ & $\begin{array}{l}\text { Concentration } \\
\text { (mg/liter) }\end{array}$ & $\begin{array}{l}\text { Reliability-- } \\
\text { applicability }\end{array}$ \\
\hline 3 & Analyses of runoff fron caal storage & 22 & $0.3-2.0$ & A \\
\hline 10 & No data available & - & & \\
\hline \multirow[t]{2}{*}{19} & Analyses of U.S. Steel clean coke PDU condensate & 23 & 33,000 & A \\
\hline & Analyses of PERC Synthane PDU condensate & 27 & $2500-11,000$ & B \\
\hline 23 & $\begin{array}{l}\text { No data available, assumed to be small due to nature } \\
\text { of the stream }\end{array}$ & & Trace & B \\
\hline 25 & $\begin{array}{l}\text { Calculated, assuming } 97 \text { to } 98 \% \text { removal in ammonia } \\
\text { stripper }\end{array}$ & & $<100$ & A \\
\hline 27 & $\begin{array}{l}\text { No data avai able, assumec to be small due to nature } \\
\text { of the stream }\end{array}$ & & Trace & A \\
\hline 37 & Water of rethanation free of ammonia & 30 & $\sim_{0}$ & A \\
\hline 42,53 & $\begin{array}{l}\text { Analyses of ash qLenching water from Koppers-Totzek } \\
\text { gasifier }\end{array}$ & 32 & 154 & A \\
\hline 43,57 & Analyses of boiler blowdonn from petroleum refineries & 4 & $<1-50$ & A \\
\hline 58 & No data arai`able & & & \\
\hline 59 & Analyses if coolirg water from petroledim refineries & 4 & $<1-80$ & A \\
\hline 66,67 & $\begin{array}{l}\text { Water tre } \text { tment wistes will reflect anjurit of ammonia } \\
\text { in river witer, should te small }\end{array}$ & & no & $\mathrm{C}$ \\
\hline
\end{tabular}

\footnotetext{
${ }^{a} A$, very reliable-spp:icatle; $B$, irtermediate; $:$ marginally reliable-applicable.
} 
Table 8.7. Data sources for hydrogen sulfide

\begin{tabular}{|c|c|c|c|c|}
\hline $\begin{array}{l}\text { Stream } \\
\text { No. }\end{array}$ & Comments & $\begin{array}{l}\text { Data source } \\
\text { (ref.) }\end{array}$ & $\begin{array}{l}\text { Concentration } \\
\quad(\mathrm{mg} / \text { liter) }\end{array}$ & $\begin{array}{l}\text { Reliability- } \\
\text { applicability }\end{array}$ \\
\hline 3 & $\begin{array}{l}\text { Analyses of runoff from coal storage shows no } \\
\text { dissolved } \mathrm{H}_{2} \mathrm{~S} \text {, but some sulfides and sulfates } \\
\text { are present }\end{array}$ & 22 & 20 & A \\
\hline 10 & No data available & & & \\
\hline \multirow[t]{3}{*}{19} & Analyses of U.S. Steel clean coke PDU condensate & 23 & (total sulfide) & B \\
\hline & $\begin{array}{l}\text { Analiyses of FMC COED pilot plant first- and second-stage } \\
\text { condensate }\end{array}$ & 25 & $\begin{array}{l}0.01-0.18 \% \\
\text { (total sulfur) }\end{array}$ & B \\
\hline & Analyses of PERC Synthane PDU condensate & 27 & (total sulfur) & B \\
\hline 23 & $\begin{array}{l}\text { No data available, but no } \mathrm{H}_{2} \mathrm{~S} \text { will be present due } \\
\text { to the nature of the stream }\end{array}$ & & 0 & A \\
\hline$\underline{25}$ & $\begin{array}{l}\text { No data available, } \mathrm{H}_{2} \mathrm{~S} \text { assumed to be stripped out } \\
\text { with } \mathrm{NH}_{3}\end{array}$ & & $<25$ & $B$ \\
\hline$\geq 7$ & $\begin{array}{l}\text { No data available, but since this stream is formed } \\
\text { by regeneration of the salfur sorption beds, a } \\
\text { large amount of sulfur is expected }\end{array}$ & & 1000 & C \\
\hline 37 & Water of methanation free of sulfur contamination & 30 & 0 & A \\
\hline 42,53 & $\begin{array}{l}\text { No data available, but } H_{2}^{\text {S }} \text { or sulfide are not likely } \\
\text { to be present in ash sluicing waters }\end{array}$ & & w & A \\
\hline 43,57 & Analyses of boiler blowdown from petroleum refineries & 4 & $<0.1$ & A \\
\hline 58 & No data available, but some sulfides probably present & & Trace & $\mathrm{C}$ \\
\hline 59 & Analyses of cooling water from petroleum refineries & 4 & $<0.1$ & A \\
\hline 66,67 & $\begin{array}{l}\text { Water treatment wastes will reflect quality of river } \\
\text { water, probably no } \mathrm{H}_{2} \mathrm{~S} \text { present }\end{array}$ & . & 20 & A \\
\hline
\end{tabular}

${ }_{A}{ }_{A}$, very reliable/applicable; $B$, intermediate; $C$, marginally reliable/applicable. 
-at le 8.8. Data sources for trace elements

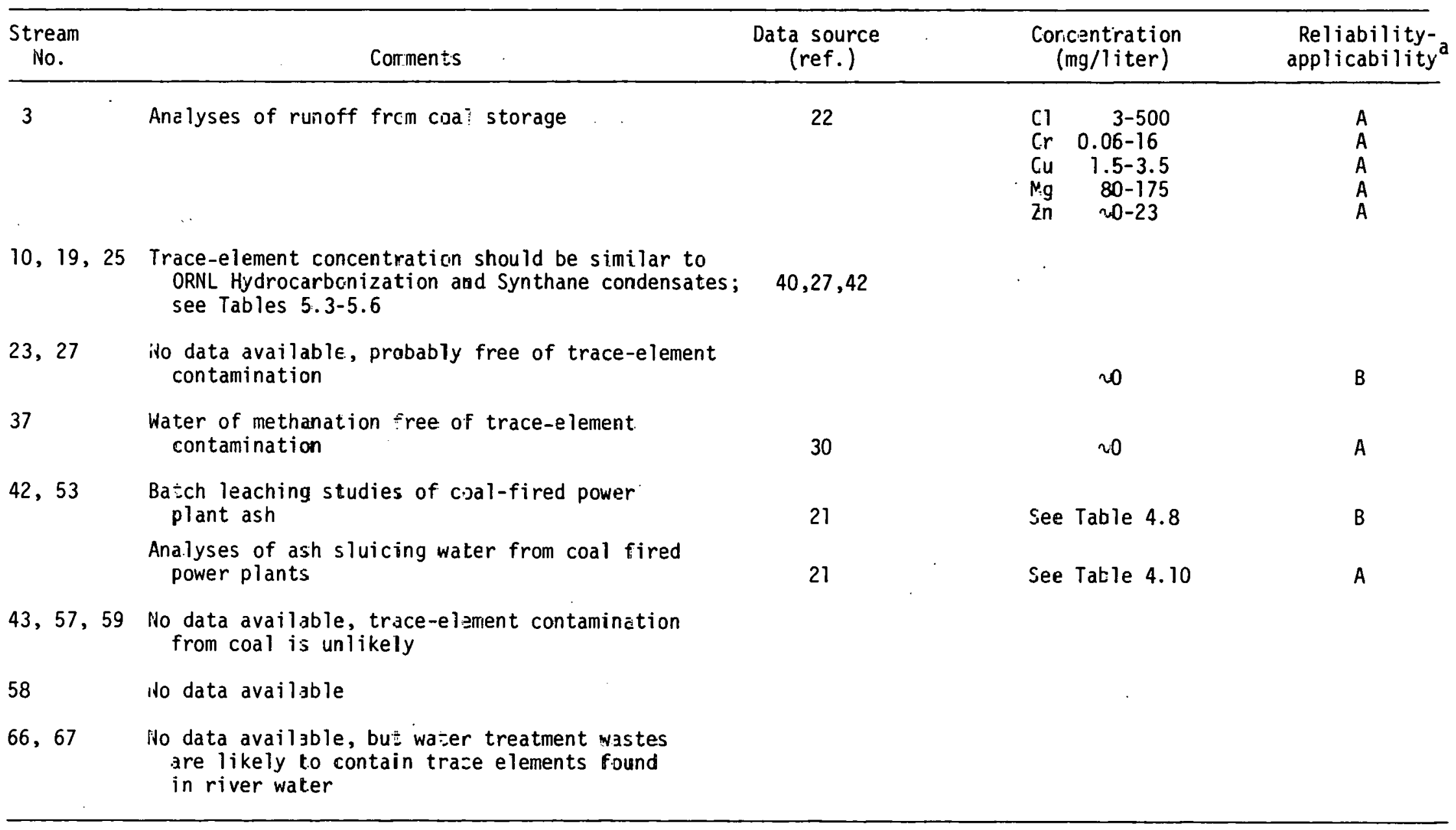

${ }_{A}$, very reliable-applicable; $B$, intermediate; $C$, marginally reliable-applicable. 
Table 8.9. Data sources for other soluble contaminants

\begin{tabular}{|c|c|c|c|c|}
\hline $\begin{array}{l}\text { Stream } \\
\text { Mo. }\end{array}$ & Comments & $\begin{array}{l}\text { Data source } \\
\quad(\text { ref.) }\end{array}$ & $\begin{array}{l}\text { Concentration } \\
\text { (mg/liter) }\end{array}$ & $\begin{array}{l}\text { Reliability- } \\
\text { applicability }\end{array}$ \\
\hline 3 & Analy'ses of runoff from coal storage & 22 & $\mathrm{SO}_{4}, 100-22,000$ & A \\
\hline 10 & No data available & & & \\
\hline \multirow[t]{2}{*}{19} & $\begin{array}{l}\text { Analyses of U.S. Steel clean coke PDU } \\
\text { condensate }\end{array}$ & 23 & $\begin{array}{l}\mathrm{CN}, 74 \\
\mathrm{SCN}, 1171\end{array}$ & $\begin{array}{l}A \\
A\end{array}$ \\
\hline & Analyses of PERC Synt lane PDU condensate & 27 & $\begin{array}{l}\text { CN, } 0.7-0.6 \\
\text { SCN, } 20-200\end{array}$ & $\begin{array}{l}\text { B } \\
\text { B }\end{array}$ \\
\hline $23,27,37$ & No data for these stræams & & & \\
\hline 25 & $\begin{array}{l}\text { No data for this stream, but will contain } \mathrm{CN} \\
\text { and SCN from stream } 23\end{array}$ & & & \\
\hline \multirow[t]{2}{*}{42,53} & $\begin{array}{l}\text { Ash sluicing stream saturated with } \mathrm{Ca}, \mathrm{Al} \text {, } \\
\text { Mg, Fe salts }\end{array}$ & 22 & & \\
\hline & $\begin{array}{l}\text { Analyses of ash quencining water from Koppers- } \\
\text { Totzek gasifier }\end{array}$ & 32 & $\mathrm{CN}, 0.52$ & A \\
\hline 43,57 & Typical values for boiler blowdown & 22 & Salts, $10-500$ & A \\
\hline 58 & No data available & & & \\
\hline 59 & Typical value for recirculating cooling water & 136 & Salts, $<2400$ & A \\
\hline 66 & Typical value for clarifier sludge & 22 & Salts, $2000-12,000$ & A \\
\hline 67 & Typical value for demineralizer waste & 22 & Salts, $4000-18,000$ & A \\
\hline
\end{tabular}

${ }_{A}^{a}$, very reliable-applicable; $B$, intermediate; $C$, marginally reliable-applicable. 
Tab'e 8.10. Daza sources for suspended oil and grease

\begin{tabular}{|c|c|c|c|c|}
\hline $\begin{array}{l}\text { Stream } \\
\quad \text { No. }\end{array}$ & Comments & $\begin{array}{l}\text { Data source } \\
\text { (ref.) }\end{array}$ & $\begin{array}{l}\text { Concentration } \\
\text { (mg/liter) }\end{array}$ & $\begin{array}{l}\text { Reliability- } \\
\text { applicability }\end{array}$ \\
\hline 3 & No oil or grease in coal storage funoff & 22 & $\mathrm{C}$ & A \\
\hline 10 & No data availajle & & & \\
\hline 19 & Analyses of FM: COED condensate ${ }^{b}$ & 25 & $0-0.5 \%$ & B \\
\hline 23 & $\begin{array}{l}\text { No data availasle, no oil or grease expecied } \\
\text { due to lature of the stream }\end{array}$ & & $\sim 0$ & B \\
\hline 25 & See note on st -eam 19 & & & \\
\hline 27 & $\begin{array}{l}\text { No data available, but only a rary small amount } \\
\text { expected due to the nature } o^{-=} \text {the strear }\end{array}$ & & Trace & C \\
\hline 37 & Water of sethanation not contaninated & 30 & च & A \\
\hline 42,53 & No data available, but no oil or grease expected & & $\sim 0$ & B \\
\hline $43,57,58$ & $\begin{array}{l}\text { No daté available, but trace contamination } \\
\text { expected due to leakage }\end{array}$ & & Trace & B \\
\hline 59 & No dat $\equiv$ available, some contam nation expected & & Trace & C \\
\hline 66,67 & Wo dats available, no contamination expected & & $\sim 0$ & B \\
\hline
\end{tabular}

${ }^{a} A$, very reliable-appiicable; $B$, intermediate; $C$, marçinally reliable-applicable.

$\mathrm{b}_{\text {The }} \mathrm{oil}$ and grease concentration is entirely dependert on the efficiency of tre phase separator used, the design of which is unknown. 
Table 8.11. Surmary of hydrocarbonization wastewa:er data

\begin{tabular}{|c|c|c|c|c|c|c|c|c|}
\hline \multirow{2}{*}{$\begin{array}{l}\text { Effluen: } \\
\text { parameter }\end{array}$} & \multirow{2}{*}{$\begin{array}{l}\text { Total waste } \\
(1 \mathrm{~b} / \mathrm{day})^{\mathbf{a}}\end{array}$} & \multirow{2}{*}{$\begin{array}{l}\text { Main } \\
\text { sources }\end{array}$} & \multirow{2}{*}{$\begin{array}{l}\text { Maximum } \\
\text { cone } \\
\text { (ppm) }\end{array}$} & & \multirow{2}{*}{$\begin{array}{c}\text { Existing } \\
\text { treatment- } \\
\text { technology } \\
\text { avai lable }\end{array}$} & \multicolumn{2}{|c|}{ Anticipated regulations } \\
\hline & & & & $\frac{\text { Hazard }}{\text { Envir }}$ & $\frac{\text { level }}{\text { Huraan }}$ & & ( $1 \mathrm{~b}$ effluent $/ 10^{6} 1 \mathrm{~b}$ coa 1 ) & ppm \\
\hline $\mathrm{pH}$ & & & & 2 & 1 & Neutralization & $6-9$ & $6-9$ \\
\hline TsS & & $\begin{array}{l}\text { Coal storage, } \\
\text { ash handling, anci } \\
\text { water treatment }\end{array}$ & 200,000 & 2 & 1 & $\begin{array}{l}\text { Clarification and } \\
\text { sedimentation }\end{array}$ & $1-7$ & $3-15$ \\
\hline Phenolies & $\begin{array}{l}2500-25,000 \\
\text { (may be recovered) }\end{array}$ & Hysrocarbonization & 6,000 & 3 & 3 & \multirow[t]{2}{*}{$\begin{array}{l}\text { Liquid-liquid extraction and } \\
\text { biological oxidation (expensive } \\
\text { unproven for coal conversion wa }\end{array}$} & ve and $0.01-0.15$ & $0.03-0.3$ \\
\hline $\begin{array}{l}\text { Other soluble } \\
\text { hydrocarbons } \\
\text { (benzenz, fatty } \\
\text { acids) }\end{array}$ & $250-25 c 0$ & Hiytrocarbonization & 1,000 & 2 & 2 & & $\begin{array}{l}\text { Bastes) } 2-15 \\
\text { COD, } 10-150\end{array}$ & $\begin{array}{c}4-30 \\
20-350\end{array}$ \\
\hline $0 i 1$ and grease & $1500-15,000$ & $\begin{array}{l}\text { Leaks, plant washdown } \\
\text { and hydrocarbonization }\end{array}$ & 10,000 & 2 & 2 & Separators & $0.5-8$ & $1.0-16$ \\
\hline $\begin{array}{l}\text { Dissol ved gases } \\
\left(\mathrm{NH}_{3}, \mathrm{H}_{2} \mathrm{~S} \text {, etc. }\right)\end{array}$ & Recovered for sale:s & $\begin{array}{l}\text { Hydrocarbonization and } \\
\text { acidagas :reatmeat }\end{array}$ & $\begin{array}{l}\mathrm{NH}_{3}, \quad 30,000 \\
\mathrm{H}_{2} \mathrm{~S}, \quad 1,000\end{array}$ & & & Stripping columns & $\begin{array}{r}0.4-2.5 \\
0.07-0.1\end{array}$ & $\begin{array}{r}0.8-5.0 \\
0.02-0.2\end{array}$ \\
\hline $\begin{array}{l}\text { Other soluble } \\
\text { contaminants }\end{array}$ & $\begin{array}{ll}C N & 1-2<0 \\
S C N & 3-3000\end{array}$ & & $\begin{array}{r}100 \\
1200\end{array}$ & 3 & 3 & & $0.01-0.05$ & $0.02-0.1$ \\
\hline Trace elements & & Ash handling and coal & & & & Hone & & \\
\hline Ag & 1 & Storage & c & $1-3$ & $1-3$ & & 0.05 & 0.1 \\
\hline As & 228 & & c & $1-3$ & $1-3$ & . & 0.12 & 0.25 \\
\hline Ba & 150 & & c & $1-3$ & $1-3$ & & 1.0 & 2.0 \\
\hline cd & 117 & & c & $1-3$ & $1-3$ & & 0.07 & 0.15 \\
\hline $\mathrm{Cr}$ & 480 & & c & $1-3$ & $1-3$ & & $0.05-0.5$ & $0.1-1.0$ \\
\hline $\mathrm{Cr}^{6+}$ & & & c & $1-3$ & $1-3$ & & $0.003-0.1$ & $0.007-0.3$ \\
\hline $\mathrm{Cu}$ & 444 & & c & $1-3$ & $1-3$ & & 0.5 & 1.0 \\
\hline $\mathrm{Fe}$ & 561,000 & & c & $1-3$ & $1-3$ & & 0.5 & 1.0 \\
\hline $\mathrm{Hg}$ & 5.4 & & c & $1-3$ & $1-3$ & & 0.0002 & 0.0005 \\
\hline m & 1608 & & c & $1-3$ & $1-3$ & & 0.5 & 1.0 \\
\hline $\mathbf{H i}$ & 666 & & c & $1-3$ & $1-3$ & & 0.5 & 1.0 \\
\hline $\mathrm{Pb}$ & 858 & & c & $1-3$ & $1-3$ & & 0.05 & 0.1 \\
\hline Se & 60 & & $c$ & $1-3$ & $1-3$ & & 0.5 & 1.0 \\
\hline $2 n$ & 13,500 & & $c$ & $1-3$ & $1-3$ & & 0.5 & 1.0 \\
\hline PAH & $2-50$ & $\begin{array}{l}\text { Hydrocarbonization, leaks, } \\
\text { and spills }\end{array}$ & & 2 & 3 & None & Unknown & \\
\hline
\end{tabular}

${ }^{a}$ Based on coal feed 15,000 tons/day $\left(3 \times 10^{10} 16 /\right.$ day $)$.

bHazardousness: 1, fairly innocucus; 2, endesirable; 3, very hazardous.

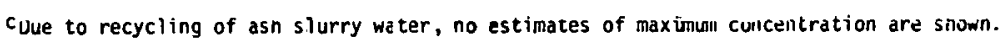


Table 8.11 also summarizes production rates, sources, maximum concentrations, and hazard level of each effluent parameter. This table is a condensation of the data presented in Tables 8.1-8.10.

A number of cleanup technologies relevant to the cleanup of coal conversion aqueous effluents have been assessed for their adaptability to the specific pollutants found in coal hydrocarbonization wastewater. A summary of these processes, shown in Table 8.12 , lists the potential applicability, economics, raw material requirements, process compatability, operating conditions, state of development, environmental problems, energy requirements, and availability of each. The economics of the various processes, shown graphically in Fig. 8.1, compare the cost per pound of organic material degraded or removed to the remaining residual organic concentration. In most cases, the organic level is equivalent to the phenolic content. Indications are that almost any level of removal can be achieved if one is willing to pay the cost. The optimum amount of cleanup will require much future interaction between industry, environmental control technology developers, human and environmental effects assessors, and federal effluent regulations administrators.

\section{REFERENCES}

1. E. T. Coles, Commercial Plant Process Evaluation Report, Coalcon, New York, (Aug. 15, 1975).

2. C. E. Jahnig and R. R. Bertrand, "Environmental Aspects of Coal Gasification," Chem. Eng. Prog. 72(8), 51 (1976).

3. EPA, Development Document for Effluent Limitations Guidelines and New Source Performance Standards for the Petroleum Refining Point Source Category, EPA-440/1-74-014-a (April 1974). 
Table 8.12. Summary of control technologies

\begin{tabular}{|c|c|c|c|c|c|c|}
\hline & $\begin{array}{l}\text { Biological } \\
\text { oxidaticn }\end{array}$ & Adsorption & Ozonation & $\begin{array}{l}\text { Coagulation- } \\
\text { flocculation }\end{array}$ & $\begin{array}{l}\text { Solvent } \\
\text { extraction }\end{array}$ & $\begin{array}{l}\text { Membrane } \\
\text { processes }\end{array}$ \\
\hline $\begin{array}{l}\text { Potential } \\
\quad \text { applicabillity }\end{array}$ & High & High & Moderate & High & Moderate & Low \\
\hline Economics & $\begin{array}{l}\$ 0.15-\$ 0.25 / 1 \mathrm{~b} \text { phenol } \\
\$ 6000-\$ 10,000 / 10^{6} \mathrm{gal}\end{array}$ & So.50- $\$ 1 / 1 \mathrm{~b}$ phenol & $\$ 0.60-\$ 1 / 1 \mathrm{~b}$ phenol & $\begin{array}{c}>\$ 0.01 / 1 \mathrm{~b} \text { organic } \\
\$ 80 / 10^{6} \mathrm{ga} 1\end{array}$ & $\begin{array}{l}\$ 0.07 / 1 \mathrm{~b} \text { ghenol } \\
\$ 3000 / 10^{6} \mathrm{gal}\end{array}$ & $\begin{array}{l}\$ 0.05-\$ 0.15 / 16 \text { phenol } \\
\$ 2000-\$ 6000 / 10^{6} \text { gal }\end{array}$ \\
\hline Raw materials & None to little & $\begin{array}{l}\text { Charcoal or } \\
\text { other sorbers }\end{array}$ & None & $\begin{array}{l}\text { Lime or } \\
\text { other agents }\end{array}$ & Solvent & Membrane material \\
\hline $\begin{array}{l}\text { Process } \\
\text { compatibility }\end{array}$ & Moderate to high & High & High & High & Moderate & Low to moderate \\
\hline $\begin{array}{l}\text { Operating } \\
\text { conditions }\end{array}$ & $\begin{array}{c}\text { Moderate temperature } \\
\text { and } \mathrm{pH}\end{array}$ & $\begin{array}{l}\text { Moderate, except } \\
\text { for regeneration }\end{array}$ & Little known & Moderate & Moderate & Moderate \\
\hline $\begin{array}{l}\text { State of } \\
\text { deve lopment }\end{array}$ & High & Moderate to high & Fair & High & Moderate to high & Moderate \\
\hline $\begin{array}{l}\text { Additional environ- } \\
\text { mental problems }\end{array}$ & Disposal of sludges & $\begin{array}{l}\text { D- sposal of } \\
\text { spent sorber }\end{array}$ & $\begin{array}{l}\text { No trace- } \\
\text { element remover }\end{array}$ & $\begin{array}{l}\text { Disposal of sludges, } \\
\text { heavy metal sludges }\end{array}$ & $\begin{array}{l}\text { Little to none } \\
\text { if product salable }\end{array}$ & $\begin{array}{l}\text { Concentrated } \\
\text { aqueous waste stream }\end{array}$ \\
\hline Energy requi rements & Low & $\begin{array}{l}\text { Low (except for } \\
\text { regeneration) }\end{array}$ & $\mathrm{High}$ & Low to moderate & Moderate to high & Moderate to high \\
\hline $\begin{array}{l}\text { Process } \\
\text { availability }\end{array}$ & High & High & Moderate & High & Moderate to high & Moderate to high \\
\hline
\end{tabular}

${ }^{a}$ An aqueous stream with contaminarits in excess of regulations will require additional treatment; product stream will need to be disposed of if not salable. 
ORNL DWG 78-344R

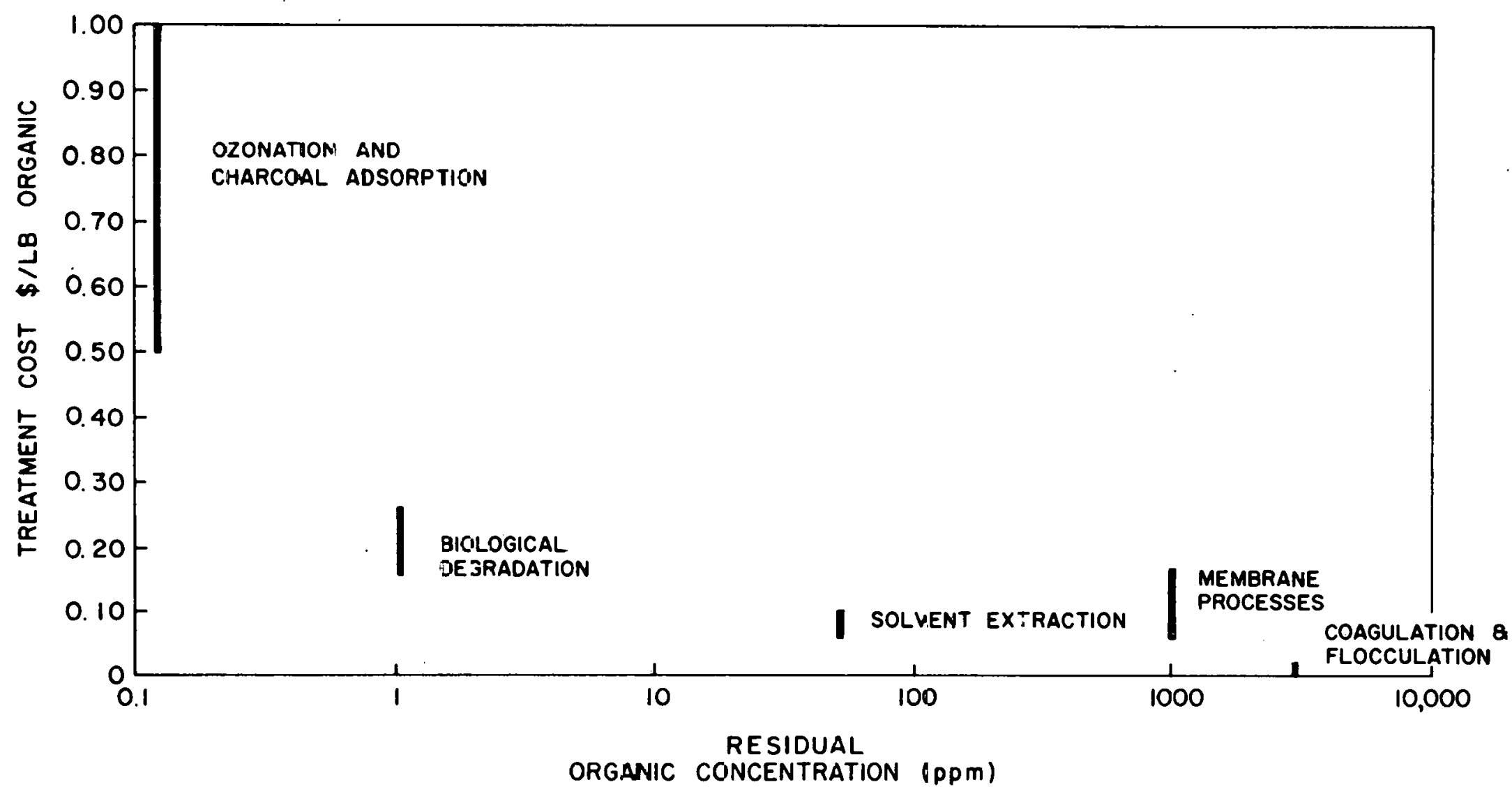

Figl. 8.1. Economic costs of environmental control

technologies for aq jeous coal conversion wastes. 
4. G. W. Reid and L. E. Streebin, Evaluation of Waste Waters from Petroleum and Coal Processing, EPA-R2-72-001 (December 1972).

5. E. M. Magee, C. E. Jahnig, and H. Shaw, Evaluation of Pollution Control in Fossil Fuel Conversion Processes, Gasification, Section 1, Koppers-Totzek Process, EPA-650/2-74-009a (January 1974).

6. C. D. Kalfaldelis and E. M. Magee, Evaluation of Pollution Control in Fossil Fuel Conversion Processes, Gasification, Section 2, Synthane Process, EPA-650/2-74-009b (June 1974).

7. H. Shaw and E. M. Magee, Evaluation of Pollution Control in Fossil Fuel Conversion Processes, Gasification, Section 3, Lurgi Process, EPA-650/2-74-009c (JuTy 1974).

8. C. E. Jahnig and E. M. Magee, Evaluation of Pollution Control in Fossil Fuel Conversion Processes, Gasification, Section $4, \mathrm{CO}_{2}$ Acceptor Process, EPA-650/2-009d (December 1974).

9. C. E. Jahnig, Evaluation of Pollution Control in Fossil Fuel Conversion Processes, Gasification, Section 5, Bigas Process, EPA-650/2-74-009g (May 1975).

10. C. E. Jahnig, Evaluation of Pollution Control in Fossil Fuel Conversion Processes, Gasification, Section 6, Hygas Process, EPA-650/2-74-009h (August 1975).

11. C. E. Jahnig, Evaluation of Pollution Control in Fossil Fuel Conversion Processes, Gasification, Section 7, U-Gas Process, EPA-650/2-74-009i (September 1975).

12. C. E. Jahnig, Evaluation of Pollution Control in Fossil Fuel Conversion Processes, Gasification, Section 8, Winkler Process, EPA-650/2-74-009j (September 1975). 
13. C. D. Kalfadelis and E. M. Magee, Evaluation of Pollution Control in Fossil Fuel Conversion Process, Liquefaction, Section 1, COED Process, EPA-650/2-74-009e (January 1975).

14. C. E. Jahnig, Evaluation of Pollution Control in Fossil Fuel Conversion Processes, Liquefaction, Section 2, SRC Process, EPA-650/2-74-009f (March 1975).

15. C. E. Jahnig, Evaluation of Pollution Control in Fossil Fuel Conversion Processes, Liquefaction, Section 3, H-Coal Process, EPA-650/2-74-009m (October 1975).

16. F. Glaser, A. Hershaft, and R. Shaw, Emissions from Processes Producing Clean Fuels, BA 9075-015 (March 1974).

17. C. R. Gibson, C. A. Hammons, and D. S. Carneron, "Environmental Aspects of El Paso's Burnham I Coal Gasification Complex, "Symposium Proceedings: Environmental Aspects of Fuel Conversion Technology, EPA-650/2-74-118 (May 1974).

18. W. A. Parsons and R. A. Ashworth, "Coal Conversion Process Wastewater Control," Symposium Proceedings: Environmental Aspects of Fuel Conversion Technology, II, EPA-650/2-76-149 (June 1976).

19. J. R. Martin, "Union Carbide's 'Coalcon' Process," p. 869 in the Proceedings of the Clean Fuels from Coal, Symposium II, Illinois Institute of Gas Technology, Chicago, June 23-27, 1975.

20. Dravo Corp., Conceptual Commercial Design and Commercial Feasibility Evaluation for Clean Boiler Fuel Facility, FE-1772-13 (February 1976).

21. Radian Corp., Environmental Effects of Trace Elements from Ponded Ash and Scrubber Sludge, EPRI-202 (September 1975). 
22. EPA, Development Document for Effluent Limitations Guidelines and New Source Performance Standards for the Steam Electric Power Generating Point Source Category, EPA-440/1-74-029-a (October 1974).

23. U.S. Stee 1 Engineers and Consultants, Inc., Clean Coke Process (Summary of Bench-Scale Studies), OCR-RDR-104, IR-1 (August 1974).

24. FMC Corp., Char 0il Energy Development, OCR 73-IR2 (July 1974).

25. J. A. Hamshar, H. D. Terzian, and L. J. Scotti, "Clean Fuels from Coal by the COED Process," Symposium Proceedings: Environmental Aspects of Fuel Conversion Technology, EPA-650/2-74-118 (May 1974).

26. B. R. Clark, C. H. Ho, and M. R. Guerin, ORNL Coal Technology Program Progress Report for February 1976, ORNL/TM-5321 (Apri1 1976).

27. A. J. Forney, W. P. Haynes, S. J. Gasior, G. E. Johnson, J. P. Strakey, Jr., Analyses of Tars, Chars, Gases, and Water Found in Effluent from the Synthane Process, PERC/TPR-75/2 (November 1975).

28. A. G. Sharkey, Jr., J. C. Shultz, C. F. Schmidt, and R. A. Friedel, Mass Spectrometric Analys is Streams from Coal Gasification and Liquefaction Processes, PERC/RI-75/5 (November 1975).

29. A. J. Forney, W. P. Haynes, S. J. Gasior, G. E. Johnson, and J. P. Strakey, Jr., "Analyses of Tars, Chars, Gases, and Water Found in Effluents from the Synthane Process," Symposium Proceedings: Environmental Aspects of Fuel Conversion Technology, EPA 650/2-74-118 (May 1974).

30. P. Milios, "Water Reuse at a Coal Gasification Plant," Chem. Eng. Prog. ㄲl(6), 99 (1975). 
31. J. V. O'Gorman and P. L. Walker, Jr., Mineral Matter and Trace Elements in U.S. Coals, OCR-RD 61-IR2 (July 1972).

32. J. F. Farnsworth, D. M. Mitsak, and J. F. Kamody, "Clean Environment with Koppers-Totzek Process," Symposium Proceedings: Environmental Aspects of Fuel Conversion Technology, EPA-650/2-74-118 (May 1974).

33. U.S. Public Health Service, Atmospheric Emissions from Petroleum Refineries, USPHS-763 (1960).

34. R. L. Cuīp and G. L. Cū̄p, Advanced Wastewater Treatment, Van Nostrand Reinhold, New York, 1971.

35. W. J. Weber, Jr., Physicochemical Processes for Water Quality Control, Wiley, New York, 1972.

36. Standard Methods for the Examination of Water and Wastewater, American Public Health Association, 13th ed. (1971).

37. C. W. Chambers et a1., "Degradation of Aromatic Compounds by PhenolAdapted Bacteria," J. Water Pollut. Control Fed. 35(12), 1517 (1963).

38. R. R. Ruch, H. J. Gluscoter, and N. F. Shimp, Occurence and Distribution of Potentially Volatile Trace Elements, EPA-650/2-74-054 (July 1974).

39. P. Zuboric, T. Stadinchenko, and N. B. Sheffey, Distribution of Minor Elements in Coal, U.S. Geological Survey Bulletins $1117 \mathrm{~A}-11170$.

40. H. D. Cochran, Jr., C. H. Brown, Jr., P. R. Westmoreland, J. C. Rose, and R. L. Andrews, ORNL Coul Technology Program Progress Report for September 19.76, ORNL/TM-5674 (November 1976).

41. H. D. Cochran, J. B. Gibson, and G. L. Yoder, ORNL Coal Technology Program Progress Report for July 1975, ORNL/TM-5037 (October 1975). 
42. A. J. Forney, W. P. Haynes, S. J. Gasior, R. M. Kornosky, C. E. Schmidt, and A. G. Sharkey, Trace Element and Major Component Balances Around the Synthane PDU Gasifier, PERC/TPR-75/1 (August 1975).

43. A. Attari, Fate of Trace Constituents of Coal During Gasification, EPA-650/2-73-004 (August 1973).

44. D. F. S. Natusch, J. R. Wallace, and C. A. Evans, Jr., "Toxic Trace Elements: Preferential Concentration in Respirable Particles," Science 183, 202 (1974).

45. S. E. Herbes, G. R. Southworth, and C. W. Gehrs, Organic Contaminants in Aqueous Coal Conversion Effluents: Environment Consequences and Research Priorities, CONF-760632-1, ORNL/ESD-880 (August 1976).

46. EPA, Development Document for Effluent Limitations Guidelines and New Source Performance Standards for the Steel Making Segment of the Iron and Steel Manufacturing Point Source Category EPA-440/174-024-a (June 1974).

47. EPA, Effluent Guidelines and Standards for Iron and Steel Manufactoring Point Source. Category, 39 FR 24114 (June 28, 1974).

48. EPA, Effluent Guidelines and Standards for Petroleum Refining Point Source Category, 16560 (May 9, 1974); 39 FR 32614 (Sept. 10, 1974); 40 FR 21939 (May 20, 1975).

49. EPA, Effluent Guidelines and Standards for Steam Electric Power Generating Point Source Category, 39 FR 36186 (Oct. 8, 1974); 40 FR 7095 (Feb. 19, 1975); 40 FR 23987 (June 4, 1975). . 
50. EPA, Effluent Guidelines and Standards for Coal Mining Point Source Category, 40 FR 48830 (Oct. 17, 1975).

51. U.S. Public Health Service, U.S. Public Health Service Drinking Water Standards, p. 32, U.S. Govt. Printing Office, Washington, D.C. (1972).

52. Code of Federal Regulations, 40 CPR 141, Federal Register 40 FR 59565, Dec. 24, 1975, amended by 41 FR 28402 (July 9, 1976).

53. American Water Works Association, "Quality Goals for Public Water," Statement of Policy, J. Am. Water Works Assoc. 60, 1317 (1968).

54. F. B. Taylor, "Trace Elements and Compounds in Waters," J. Am. Water Works Assoc. 63, 728 (1971).

55. Illinois State Rules, Environment Reporter 766, 0509 (June 6, 1975).

56. H. Juntgen and J. Klein, "Purification of Waste Water from Coking and Coal Gasification Plants Using Activated Carbon," (preprint) Division of Fuel Chemistry, American Chemical Society of Atlantic City, N.J., Sept. 8-13, 1974.

57. G. J. Capestany, G. J. McDaniels, and J. L. Opgrande, "The Influence of Sulfate on Biological Treatment of Phenol-benzoldahyde Waste," J. Water Pollut. Control Fed. 49 (2), 257 (1977).

58. D. D. Lee, ORNL personal communication, 1977.

59. J. W. Patterson and R. A. Minear, Wastewater Treatment Technology, zind ed., Illinois Institute of Environmental Qualily, Chicayu, 1973.

60. J. Barker and R. Thompson, Biological Removal of Carbon and Nitrogen Compounds from Coke Plant Wastes, EPA-R2-73-167, (1973).

61. E. Berth et al., "Summary Report on the Effects of Heavy Metals on the Biological Treatment Process," J. Water Pollut. Control Fed. 37, $86(1965)$. 
62. E. Moulton and K. Shumate, "The Physical and Biological Effects of Copper on Aerobic Biological Waste Treatment Processes," Proceedings of the 18th Indiana Waste Conference, Purdue Univ. Ext. Ser. 115, 602 (1963).

63. S. Jackson and V. Brown, "Effect of Toxic Wastes on Treatment Processes and Watercourses," Water Pollut. Control (London), 292 (June 1970).

64. M. Yamada et al., "Change of Mercurial Compounds in Activated Sludge," J. Fermentation Technol. 47, 155 (1969).

65. M. H. Cheng, J. W. Patterson, and R. A. Minear, "Heavy Metals Uptake by Activated Sludge," J. Water Pollut. Control Fed. $\underline{47}(2)$, $363(1975)$.

66. T. Stones, "The Fate of Iron and of Phosphates During the Treatment of Sewage," J. Inst. Sewage Purif., Part 4, 405 (1956).

67. T. Stones, "The Fate of Copper During the Treatment of Sewage," J. Inst. Sewage Purif., Part 1,82 (1958).

68. T. Stones, "The Fate of Nickel During the Treatment of Sewage," J. Inst. Sewage Purif., Part $\underline{2}, 252$ (1959).

69. T. Stones, "The Fate of Zinc During the Treatment of Sewage," J. Inst. Sewage Purif., Part $\underline{2}, 254$ (1959).

70. T. Stones, "The Fate of Lead During the Treatment of Sewage," Inst. Sewage Purif. Part 2, 221 (1960).

71. M. M. Ghosh and P. D. Zugger, "Toxic Effects of Mercury on the Activated Sludge Processes," J. Water Pollut. Control Fed. $\underline{45}, 424$ (1973). 
72. G. W. Malaney et al., "Resistance of Carcinogenic Organic Compounds to Oxidation by Activated Sludge," J. Water Pollut. Control Fed. 39(12), 202 (1967).

73. W. F. Gerber et a7., "Thermophilic Digestion at the Hyperion Treatment Plant," J. Water Pollut. Control Fed. 47(5), 951 (1975).

74. R. G. Muck and C. P. L. Grady, Jr., "Temperature Effects on Microbial Growth in CSTR's," J. Environ. Eng. Div., Proc. Am. Soc. Civ. Eng. 100, 1147 (1974).

75. K. C. Lin and G. W. Heinke, "Plant Data Analysis of Temperature Significance in the Activated Sludge Processes," J. Water Pollut. Control Fed. $\underline{49}(2), 287$ (1977).

76. L. C. Matsch and R. F. Drnevich, "Autothermal Aerobic Digestion," J. Water Pollut. Control Fed. 49(2), 296 (1977).

77. P. A. Blakeslee, "Monitoring Considerations for Municipal Wastewater Effluent and Sludge Application to the Land," EPA and the U.S. Dept. of Agriculture, Universities Workshop, Champaign, I11., JuTy 9-13, 1973.

78. M. L. Berrow and J. Webber, "Trace Elements in Sewage Sludge," J. Sci. Food Agric. 23, 93 (1972).

79. L. E. Sommers et al., "Chemical Composition of Sewage Sludge from Selected Indiand Cities," Indiana Acad. Sci. Monogr. 83, 424 (1973).

80. A. L. Yage, Fate and Effects of Trace Elements in Sewage When Applied to Agricultural Lands: A Literature Review Study, EPA-670/2-74-005 (1974).

81. EPA. "The Effect of Chlorination on Selected Organic Chemicals," Water Pollut. Control Res. Ser. 12020 EXG (March 1972). 
82. R. H. Burttshell et al., "Chlorine Derivatives of Phenol Causing Taste and Odor," J. Am. Water Works Assoc. 51, 205 (1959).

83. R. L. Jolley, "Chlorination Effects on Organic Constituents in Effluents from Domestic Sanitary Sewage Treatment Plants," ORNL/TM-4290 (October 1973).

84. C. E. Warren, Biology and Water Pollution Control, W. B. Saunders, Philadelphia, 1971.

85. S. G. Sforzolini et al., "Decontamination of Water Contaminated with Polycyclic Aromatic Hydrocarbons (PAH). I. Action of Chlorine and Ozone on PAH Dissolved in Doubly Distilled and De-ionized. Water," Ig. Mod. 66 (3), 309 (1974); also ORNL-tr-2960.

86. E. Muller and J. K. Reichert, "Kanzerogene Substanzen in Wasser and Boden XXV. Tier-experimentelle Prüfung der Kanzerogenität Chlorierter Derivate des 3,4-Benzpyrens," Arch. Hyg. Bakteriol. $\underline{153}, 26$ (1969).

87. H. R. Eisenhauser, "Dephenolization by Ozonolysis," p. 467 in Water Research, vol. 5, Pergamon Press, London, 1971.

88. J. K. Reichert, "Examination for the Elimination of Carcinogenic Aromatic Polycyclics in the Treatment of Drinking Water, with Special Consideration of Ozone," Wasser Abwasser 110:18, 477 (1969).

89. W. Hopf, "Treatment of Water with Ozone and Activated Carbon (Dusseldorf Process) . -- Part I," Wasser Abwasser 111:2, 83 (1970).

90. D. A. Hall and G. R. Nellist, "Phenolic Effluents Treatment," Chem. Trade J. 156, 786 (1965).

91. R. H. Kroop, Treatment of Phenolic Aircraft Paint Stripping Wastewater, AFWL-TF-72-181 (January 1973). 
92. J. P. Gould and W. J. Weber, Jr., "Oxidation of Phenols by Ozone," J. Water Pollut. Control Fed. 48(1), 47, (1976).

93. G. L. Anderson, "Ozonation of High Levels of Phenol in Water," Presented at the 68th Annual Meeting of the American Institute of Chemical Engineers, Los Angeles, Nov. 16-20, 1975.

94. T. R. Camp, "Flocculation and Flocculation Basins," Trans. Am. Soc. Civ. Eng. 120, 1 (1955).

95. H. E. Hudsnn, "Physiral Aspects of Flocculation," J. Am. Water Works Assoc. 57, 855 (1965).

96. U. F. Bishop et al., "Studies on Activated Carbon Treatment," J. Water Pollut. Control Fed. $\underline{39}$, 188 (1967).

97. R. B. Dean, "Colloids Complicate Treatment Process," Environ. Sci. Technol. $\underline{3}, 820$ (1969).

98. R. Nilson, "Removal of Metals by Chemical Treatment of Municipal Wastewater," Water Res. $\underline{5}, 51$ (1975).

99. G. L. Culp and R. L. Culp, "New Concepts in Water Purification," Van Nostrand Reinhold, New York, 1974.

100. Chemical Marketing Reporter, Oct. 3, 1977.

101. J. P. Earhart et al., "Recovery of Organic Pollutants via Solvent Extraction," Chem. Eng. Prog. 73(5), 67 (1977).

102. L. I. Volkova et al., "Chemical Composition and Methods for Purifying Phenolic Waste Waters Resulting from Rapid Thermolyș is of Lignites of the Irsha-Boradino and Moscow Regions," vol. 13, p. 20, Trudy Kalininskii Politekhnicheskii Instutut, Moscow, 1972.

103. M. R. Beychok, "Coal Gasification and the Phenosolvan Process," Am. Chem. Soc., Div. Fuel Chem 19(5), 85 (1974). 
104. G. Rey, M. Dick, and P. Des Rosiers, "EPA's R\&D Program for Activated Carbon," Chem. Eng. Prog. 69(11), 45 (1973).

105. V. A. Brunotts, R. T. Lynch, and G. R. Van Stone, "Granular Carbon Handles Concentrated Waste," Chem. Eng. Prog. 69(8), 81 (1973).

106. J. C. Davis, "Activated Carbon: Prime Choice to Boost Secondary Treatment," Chem. Eng. $\underline{84}(8), 81$ (1977).

107. F. E. Bernardin, Jr., "Selecting and Specifying Activated Carbon Adsorption Sys tems," Chem. Eng. 83(22), 77 (1976).

108. J. T. Cookson, Jr., "The Adsorption Chemistry of Organics from Waters on Activated Carbon," AIChE Symp. Ser. 151, 376 (1975).

109. D. G. Hager, "Waste Water Treatment via Activated Carbon," Chem. Eng. Prog. 72 (10), 57 (1976).

110. C. E. Baker, E. W. Clark, V. W. Jesernig, and C. H. Hueter, "Recovering para-Cresol from Process Effluents," Chem. Eng. Prog. 69 (8), 77 (1973).

111. C. Shimmel and D. B. Griffin, Treatment and Disposal of Complex Industrial Wastes, EPA-600/2-76-123 (November 1976).

112. F. H. Gardner and A. R. Williamson, Naval Stores Wastewater Purification and Reuse by Activated Carbon Treatment, EPA-600/276-227 (October 1976).

113. H. Juntgen and J. Klein, "Purification of Wastewater from Coking and Coal Gasification Plants Using Activated Carbon," Energy Sources $2(4), 311$ (1976).

114. A. J. Forney et al., Internal Quarterly Technical Progress Report, April-June 1975, PERC/QTR-75/2; July-September 1975, PERC/QTR-75/3; October-December 1975, PERC/QTR-75/4; January-March 1976, PERC/QTR- 
76/1; April-June 1976, PERC/QTR-76/2; and July-September 1976, PERC/QTR-76/3.

115. D. G. Argo and G. L. Culp, "Heavy Metals Removal in Wastewater Treatment Processes: Part 1," Water Sewage Works 119, 62 (1972).

116. K. D. Linstedt, C. P. Houck, and J. T. O'Connor, "Trace Element Removals in Advanced Wastewater Treatment Processes," J. Water Pollut. Control Fed. 43, 1507 (1971).

117. P. N. Cheremisinoff and Y. H. Habib, "Cadmium, Chromium, Lead, Mercury: Part 2 - Removal Techniques," Water Sewage Works 119 , 46 (1972).

118. A. W. Loven, "Perspectives on Carbon Regeneration," Chem. Eng. Prog. 69(11), 56 (1973).

119. C. von Dreusche, Jr., "Process Aspects of Regeneration in a Multiple Hearth Furnace," AIChE Symp. Ser. 151, 432 (1975).

120. S. B. Smith, "The Thermal Transport Process," Chem. Eng. Prog. 피(5), 87 (1975).

121. S. B. Smith, "The Regeneration of Spent Powdered Activated Carbon by the Thermal Transport Process," AIChE Symp. Ser. 151, 405 (1975).

122. R. A. Hutchins, "Economic Factors in Granular Carbon Thermal Regeneration," Chem. Eng. Prog. 69(11), 49 (1973).

123. R. A. Hutchins, "Thermal Regeneration Costs," Chem. Eng. Prog. 기 (5), 80 (1975).

124. R. A. Hutchins, "Costs of Thermal Regeneration," AIChE Symp. Ser. 151, 423 (1973).

125. K. J. Himmelstein, R: D. Fox, and T. H. Winter, "In-place Regeneration of Activated Carbon," Chem. Eng. Prog. 69(11), 65 (1973). 
126. R. E. Rosford et a1., "Phenols, A Water Pollution Control Assessment," Water Sewage Works 123, 96 (1976).

127. R. N. Rickles; Membranes: Technology and Economics, Noyes Development Corp., Park Ridge, N.J., 1967.

128. W. A. McRae and F. B. Leitz, "Electrodialysis and Other IonSelective Processes," p. 157 in Recent Developments in Separation Science, vol. II, ed. by N. N. Li, Chemical Rubber Co., Cleveland, 1972.

129. S. Sourirajan (ed.), Reverse Osmosis and Synthetic Membranes, National Research Council of Canada, Ottawa, 1977.

130. H. E. Poda11, "Reverse 0smosis," p. 171 in Recent Developments in Separation Science, vol. II, ed. by N. N. Li, Chemical Rubber Co., Cleveland, 1972.

131. M. C. Porter and L. Nelson, "Ultrafiltration in the Chemical, Food Processing, Pharmaceutical and Medical Industries," p. 227 in Recent Developments in Separation Science, vol. II, ed. by N. N. Li, Chemical Rubber Co., Cleveland, 1972.

132. J. Markind, J. S. Neri, and R. R. Stana, "Use of Reverse Osmosis for Concentrating Waste-Soluble 0il Coolants," AIChE Symp. Ser. 151, 93 (1975).

133. I. K. Bansal, "Ultrafiltration of 0ily Wastes from Process Industries," AIChE Symp. Ser. 151, 93 (1975).

134. W. A. Duvel, Jr. and T. Helfgott, "Removal of Wastewater Organics by Reverse Osmosis," J. Water Pollut. Control Fed. 47(1), 57 (1975). 
135. E. S. K. Chian and H. H. P. Fang, "RO Treatment of Power Plant Cooling Tower Blowdown for Reuse," AIChE Symp. Ser. 151, 82 (1975).

136. T. M. Fosberg, "Reclaiming Cooling Tower Blowdown," Ind. Water Eng. $\underline{9}(4), 38(1972)$. 
ORNL/TM-6263

INTERNAL DISTRIBUTION

1-2. R. E. Barker

3. C. R. Boston

4. C. H. Brown

5. H. D. Cochran

6. E. Copenhaver

7. K. E. Cowser

8. S. G. DeCicco

9. D. E. Ferguson

10. J. F. Fisher

11. R. W. Glass

12. J. R. Hightower

13. J. K. Huffstetler

14-52. J. A. Klein

53. L. E. McNeese

54. W. W. Pitt

55. H. Postma

56. C. R. Richmond

57. M. W. Rosenthal
58. C. D. Scott

59. S. P. N. Singh

60. D. B. Trauger

61. P. R. Westmoreland

62. R. G. Wymer

63. E. L. Youngb lood

64-65. Central Research Library

66. Document Reference Section

67-68. Laboratory Records

69. Laboratory Records, RC

70. ORNL Patent Section

71. G. R. Choppin (consultant)

72. L. J. Colby, Jr. (consultant)

73. E. L. Gaden (consultant)

74. L. E. Swabb, Jr. (consultant)

75. K. D. Timmerhaus (consultant)

\section{EXTERNAL DISTRIBUTION}

76. Research and Technical Support Division, DOE, ORO, P. O. Box E, Oak Ridge, Tenn. 37830

77. D. E. Large, DOE, ORO, P. 0. Box E, Oak Ridge, Tenn. 37830

78-97. F. E. Witmer, DOE, DECT, Mail Station E-201, Washington, D.C. 20545 98-124. Technical Information Center, Uak Ridge, Tenn. 37830 